\title{
The Appropriation of Death In Classical Athens
}

Alexandra Donnison

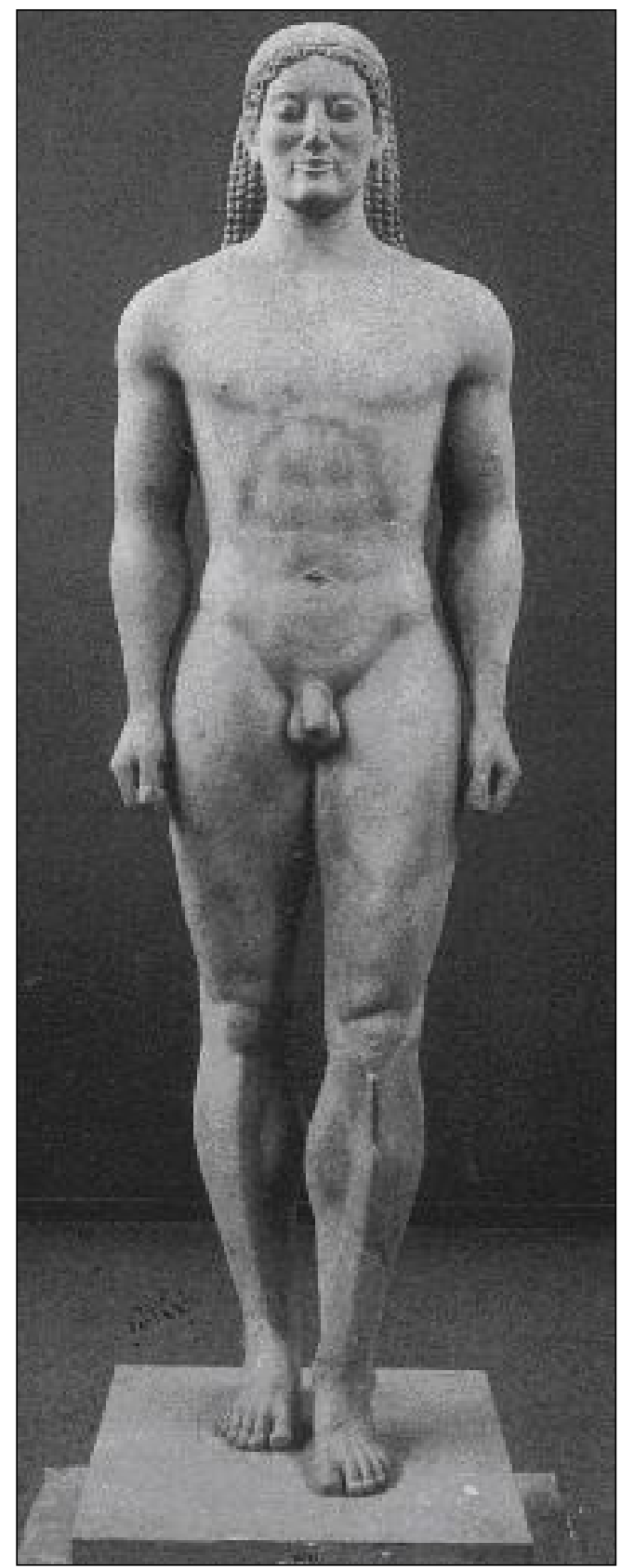

Submitted in fulfilment of the requirements for the degree of Master of Arts in Classics

Victoria University of Wellington

August 2009 


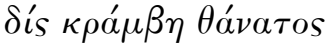

Cover picture: Anavysos. Kouros from tomb of Kroisos. c. 530 B.C.E. NM, Athens. 3851. Hurwit (2007b). Fig. 35. 


\section{$\underline{\text { Acknowledgements }}$}

To my parents, who have been there every step of the way, without their

guidance and support - and especially their sense of humour - this would not have been possible. I would also like to express thanks to my supervisor, Matthew Trundle, for his time, knowledge and guidance. Finally, but not least, I wish to express my deepest gratitude to my friends who spent countless hours proof reading this thesis, and who in the process learnt more about Ancient Greek burial customs than they ever felt necessary.

Note on translations: All translations are taken from the Loeb, unless otherwise stated. 


\section{Contents Page}

Abstract..................................................................

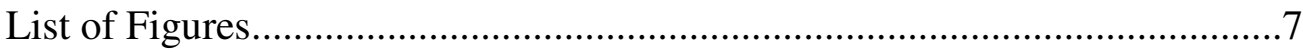

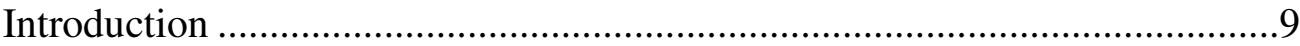

Chapter One: The Change in Burial Practices Between the Archaic and Classical Periods .......................................................................................19

Chapter Two: Why the Change in Funeral Practices Took Place ...................58

Chapter Three: The Re-emergence of the Grave Monument ........................92

Conclusion.......................................................... 127

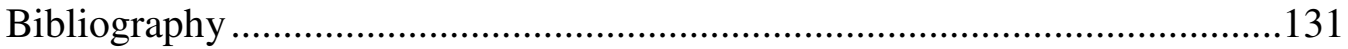

Appendix 1: Greek and Latin Primary Texts ..............................................146

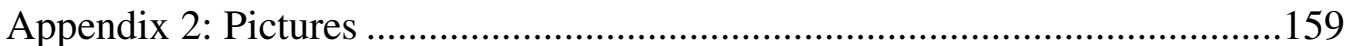




\section{$\underline{\text { Abstract }}$}

This thesis is about the change in Athenian burial practices between the Archaic and Classical periods (500-430 B.C.E.), within the oikos and the polis. I argue that during this period there was a change in both burial practice and ideology. I hypothesise that the Homeric conception of death was appropriated by the state leading to a temporary ideological change in Athens between 500-430 B.C.E., with the result that the aristocratic Athenian oikoi exhibited a trend of anti-display. There then followed another shift in ideology, whereby the Athenian aristocrats reappropriated death, taking state funerary symbols and applying them to private death, which then resulted in the re-emergence of lavish yet iconographically different grave monuments.

This is a study of varied and disparate sources ranging from archaeological evidence to later literature. It is divided into three parts. Chapter One outlines exactly what the changes in funeral practice were between the Archaic and Classical periods. It focuses on the decline of grave markers, the shift to extramural burial, the change in how funerals and death were depicted, the increased emphasis on state burial and the change in both public and private mourning practices around 480 B.C.E. I argue that there was a definite change in how the Athenians interacted with their dead, both physically and ideologically.

Chapter Two examines the reasons behind the change in burial practices around 480 B.C.E. I argue that it is improbable such a complex change had simple factors or motivations behind it but rather that the most likely cause of such a shift in attitude was a combination of complex reasons, where a few 
predominate, such as appropriation of death by the polis resulting in glorified state burials and development of democracy.

Chapter Three examines the re-emergence of grave monuments. The archaeological record reveals a reappearance of stone funerary sculpture a decade or so after the middle of the fifth century (c. 440-430 B.C.E.). I argue that the re-emergence of funeral sculpture was influenced heavily by foreign workers who brought with them their own burial practices which in turn inspired Athenian aristocrats to re-appropriate death and begin erecting private funeral monuments, however instead of only using Homeric imagery, as they had in earlier periods, they appropriated state symbols and incorporated them into private monuments. 


\section{List of Figures}

Fig. 1: Dipylon Cemetery, Athens. Geometric funerary krater. Scenes of ritual mourning (prothesis) and funeral procession of chariots. c. 750 B.C.E. New York, MMA 14.130.140. Artstor.org. I.D.: AIC_960032 downloaded on 21.08.2009.

Fig. 2: Attic grave stelae of Type I, a, b, c, about 610-525 B.C.E.; of Type II, a, b, about 530-500 B.C.E.; and of Type IIc, about 450 B.C.E. Drawings by L.F. Hall. Richter (1961) 3.

Fig. 3: Black-figure plaque. Prothesis. c. 500 B.C.E. Paris, Lourve. L.4 (MNB 905) from van Wees (1998) Fig. 1.17.

Fig. 4: Attica. Attic black-figure loutrophoros. Prothesis. Late sixth century B.C.E. New York, MMA 22.228. Kamen (2007) Fig. 14.

Fig. 5: Attic white lekythos, Vouni Painter. Visit to the grave. c. 460 B.C.E. New York, MMA 35.11.5. Oakley (2004) VII A-B.

Fig. 6: Anavysos. Kouros from tomb of Kroisos. c. 530 B.C.E. Athens, NM 3851. Hurwit (2007b) Fig. 35.

Fig 7: Athens. Grave stele. Mother and child; the stele was likely for the child (or for mother and child.) c. 530 B.C.E. Athens, NM 4472. Schmaltz (1983) tf. 3,1 .

Fig. 8: Attica. Grave stele, youth and little girl. c. 550-525 B.C.E. New York, MMA 11.185 (Head, shoulder and left hand of the girl are plaster copies from the original in Berlin.) Richter (1961) Fig. 99.

Fig. 9: Athens. Kore of Phrasikleia, by Aristion of Paros. c. 550-540 B.CE. Athens, NM 4889. Hurwit (2007) Fig. 30.

Fig. 10: Kerameikos, Athens. Stele of Hegeso. First quarter of the fourth century B.C.E. Athens, NM 3624. Artstor.org. I.D.:

SCALA_ARCHIVES_10310475454 downloaded on 23.08.09.

Fig. 11: Stele of Pausimache. First quarter of the fourth century B.C.E. Athens, NM 3964. Leader (1993) Fig. 6.

Fig 12: Kerameikos, Athens. Stele of Ampharete. Late fifth century B.C.E. Athens, Kerameikos Mus. P 659,1 221. Sutton (2004) Fig. 17.2.

Fig. 13: Plan of the Marathon tumulus. Whitley (2001) 13.20.

Fig. 14: Paros. 'Stele Giustiniani'. c. 460 B.C.E. Girl with jewellery box (bride of Hades?). Berlin, Antikenslg. Artstor.org. I.D. BERLIN_DB_1039764898 downloaded on 21.08.09. 
Fig. 15: Drawing of the monument of Pythagoras of Selymbria. Whitley (2001) 367 Fig. 13.21.

Fig. 16: Grave stele of Damasistrate, showing dexiosis. First half of 4th century B.C.E. NM 743. Artstor.org I.D. AIC_680037 downloaded on 25.08.09.

Fig. 17: Athens, Kerameikos. Stele of Dexileos. c. 394-393 B.C.E. Athens, Kerameikos Mus. P.1130. Artstor.org. I.D.: SCALA_ARCHIVES_1039779622 downloaded on 22.08.09. 


\section{$\underline{\text { Introduction }}$}

This thesis is about the change in Athenian burial practices between the Archaic and Classical periods (500-430 B.C.E.), ${ }^{1}$ within the oikos and the polis. ${ }^{2}$ I argue that during this period there was a change in both burial practice and ideology. This change is perhaps most clearly shown in the archaeological record: in Athens late Archaic grave stelae and statues declined in number relatively quickly and disappeared altogether by 480 B.C.E. ${ }^{3}$ Not until 430 B.C.E. did sculpted funerary monuments re-appear. ${ }^{4}$ How, or even if, graves were marked during this interstitial period is uncertain, as is the reason or reasons behind the disappearance of the Archaic burial marker and the appearance of the Classical monument.

Many scholars discuss this transition: the disappearance of elaborate grave makers, the period of no funerary monuments, and then the appearance of new grave monuments. Many possible explanations for these changes have been put forward including: a growth in population; a lack of space; the growth of democracy; economic reasons; legislative and political measures; the establishment of cults; control of women; as a part of a wider trend of Panhellenic restraint, or the increased importance of public burial. ${ }^{5}$ A definitive

\footnotetext{
${ }^{1}$ Throughout this thesis I will be using the B.C.E/C.E. convention and latinised names except where the Greek is more familiar, such as oikos, polis and Kerameikos.

${ }^{2}$ Oikos in this thesis refers to people related by blood, marriage, and adoption and to the property held by the family, including slaves and other movables and unmovables. Pomeroy (1997) 21. Polis is the name given to a collective group of oikoi. For a more detailed discussion of the Polis and Oikos. See Humphreys (1993) 1 - 23, particularly in the Classical period see Roy (1999) 1 - 18.

${ }^{3}$ Stears (2000) 29.

${ }^{4}$ Ibid. 41

${ }^{5}$ Boardman and Kurtz (1971) 89 - 90; Young (1951) 131; Morris (1992) 146; Snodgrass (1980)
} 
explanation of the changes has yet to be accepted, and it is the hope that this thesis will provide a forum for a detailed discussion of this change. I hypothesise that the Homeric conception of death was appropriated by the state leading to a temporary ideological change in Athens between 500-430 B.C.E., with the result that the aristocratic Athenian oikoi exhibited a trend of antidisplay. There then followed another shift in ideology, whereby the Athenian aristocrats reappropriated death, taking state funerary symbols and applying them to private death, which then resulted in the re-emergence of lavish yet iconographically different grave monuments.

Death around 500 B.C.E was no longer officially permitted to be lavishly or personally celebrated as a private experience, ${ }^{6}$ or to be used as a way for the richest clans to win favour from the rest of the demos through ostentatious funerals, grave markers, and games. The Athenian polis made death a more public concern, ${ }^{7}$ therefore the aristocratic clans were pressured to conform to a new ideology concerning death and find other ways to use their resources to display status, such as votives and liturgies. ${ }^{8}$ The re-emergence of death monuments, c. 430 B.C.E., ${ }^{9}$ indicates that the aristocratic clans no longer felt constrained by the democratic ideology and again used death monuments as a

52 - 65; Toher (1991); Stears (2000) 25 - 58; Holst-Warhaft (1992) 115; Garland (1998) 119.

${ }^{6}$ See Humphreys (1993) $22-32$.

${ }^{7}$ Ibid.

${ }^{8}$ The devices of $\lambda \epsilon \iota \tau o v \rho \gamma i ́ a$ were formal institutionalised devices whereby certain public services were assigned on a rota system to individual members of the richer sector of society. Most liturgies were concerned with Religion and Religious festivals. The other main form of liturgy in Athens was a trierarchy, personal command of a naval vessel for one year. Lysias (12.37); Demosthenes (4.36); Finley (1983) 37; Davies (1981) 9 - 37; Philips (2004) 9.

${ }^{9}$ This date is much debated; see Chapter Three pages $91-92$. 
way to display their personal wealth and wrestle the favour of the demos back from the state.

To demonstrate that there was a change in how death was commemorated between 500 B.C.E and 430 B.C.E. we must not rely solely on the archaeological record provided by surviving grave markers. It is necessary to also look closely at other sources including, but not limited to: literature; epigraphy; artwork and other archaeological evidence such as grave goods and the burials themselves. Sources for the Archaic period concerning burial practices are limited. The main archaic sources include Homer, archaeology, vases, and the lyric poets. Archaeological artefacts are rarely found in situ which makes contextualised interpretation difficult: for example grave stelae and votives in the Archaic period are very similar, and it is often the find spot of an artefact that indicates its purpose. ${ }^{10}$

The reliability of Homer as an accurate historical source is a contentious topic, but for the purposes of this thesis, I will be following Christiane SourvinouInwood's use of Homer, a controlled method with cross checks coming from archaeology and epigraphy to provide a picture of the Archaic mentality towards funerals and the commemoration of the dead. ${ }^{11}$ For instance, archaeology and epigraphy bear witness to the importance attached to funeral rituals in Archaic Greece, and their testimony corresponds closely to the Iliadic representation of funereal rites indicating that the Homeric depiction of death

\footnotetext{
${ }^{10}$ Richter (1961) vii.

${ }^{11}$ Sourvinou-Inwood (1983) 33; she also uses Hesiod as a cross check for Homer, but Hesiod is brief on matters concerning death and therefore is not a prominent source for this thesis.
} 
and mourning does represent the general attitude of the Greeks before the classical period. ${ }^{12}$ The lyric poets, including Mimnermus, Stesichorus, Alcaeus, Tyrtaeus, Callinus, Simonides and Solon, most probably represent only elite attitudes towards death. ${ }^{13}$ They present both funeral rites and mourning practices in a similar way to Homer, and therefore can be interpreted as also presenting something of the archaic view of death. ${ }^{14}$ It must be noted, that with each poet having an individual agenda, one finds many viewpoints within their poetry concerning wider archaic funeral practice in Greece. That the lyric poets discussed both death and burial practices demonstrates how central these themes were to Greek life.

Archaic loutrophoroi, plaques and other ceramics often depict the funeral. Athenian potters chose in the main to portray three scenes: the prothesis, the ekphora and the visit to the tomb. In fact, mourning for the dead is the only subject found continuously represented in iconography from the Geometric period (c. $900-700$ B.C.E.) to the Peloponnesian War (431-404 B.C.E.). ${ }^{15}$ By far the most popular funeral scene depicted was the prothesis, and with other funerary scenes, they were the most common depictions on sixth century blackfigure style vases. ${ }^{16}$ The same scenes are less well attested in the red-figure period, and ended altogether at the close of the fifth century. ${ }^{17}$

\footnotetext{
${ }^{12}$ Alexiou (1974) 14; Holst-Warhaft (1992) 114.

${ }^{13}$ Morris (1989) 297, 306 - 309; Although these poets are not all Athenian they are still Greek, and they can and will be used to provide information about Greek views of death, some of which are applicable to Athens.

${ }^{14}$ See Morris (1989) 296 - 320, Morris outlines the relevant lyric poets and their works.

${ }^{15}$ Stears (1998) 113.

${ }^{16}$ Ibid; Shapiro (1991) 629.

${ }^{17}$ Stears (1998) $113-114$.
} 
Later writers provide a retrospective view of the Archaic period in Athens. Composing centuries after the change in burial practices occurred, they were often dealing with second or third hand reports. The Athenian Constitution attributed to Aristotle (350 B.C.E.) describes the conditions in Archaic Athens leading up to the reforms of Solon, a topic also addressed by Plutarch $\left(^{\text {nd }}\right.$ century C.E.) in his Life of Solon, in which he discusses legislation brought in to target funerals and mourning and to calm civil unrest. Cicero, also, records laws attributed to Solon regarding the funeral in his discussion of the Laws of the Twelve Tables in De Legibus $(2.59$ - 66) which was written seven hundred years after Solon and draws heavily on the work of Demetrius of Phaleron. ${ }^{18}$ Demetrius of Phaleron was an orator (floruit 317 - 307 B.C.E.) who wrote about Solon's funerary legislation and himself legislated against expensive funerals and tombs. ${ }^{19}$ Therefore at best the information provided by Cicero is second hand and his source was writing four hundred years after the alleged laws, but crucially Demetrius of Phaleron, as Ian Morris points out, was 'almost certainly concerned to cast his own actions as part of a tradition going back to such a highly Athenian ancestor as Solon, and was involved in a large-scale reinterpretation of Athenian history. ${ }^{20}$ Therefore it is unlikely that Demetrius, via Cicero, provides us with a reliable account. ${ }^{21}$ With all three authors, as with the lyric poets, it is necessary to take into account the historical and social contexts in which they were writing, and their own personal agendas. For

\footnotetext{
${ }^{18}$ Cicero directly references Demetrius as his source in his De Legibus (2.66). See Appendix 1: $4 \mathrm{c}$.

${ }^{19}$ Seaford (1994) 76.

${ }^{20}$ Morris (1992/3) 36.

${ }^{21}$ Ibid
} 
example Cicero was writing from the point of view of a Roman aristocrat, and it is quite possible that he is refashioning Athenian funeral law for his own purposes. $^{22}$

The Classical period yields even more evidence for Athenian burial practices: graves have produced many artefacts; over 10,000 epitaphs have been found. ${ }^{23}$ But perhaps the most useful grave goods for this study are the lekythoi which pose an interesting problem. Lekythoi, which were mainly produced between 470-400 B.C.E ${ }^{24}$ often depicted funeral scenes unknown from the contemporary archaeological record. A favourite motif was the visit to the grave; the grave is often shown as being marked by a tomb, or stele reminiscent of those known from the Archaic period. However to date there have been no kouroi, korai, stelae or relief sculpture tombs found dating to this interstitial period. $^{25}$

Death was a central theme in Athenian tragedy. Aeschylus' Oresteia and Persae; Sophocles' Oedipus the King, Oedipus at Colonus, Ajax, Antigone and Electra; and Euripides' Alcestis and Medea all feature death as a major theme. The reliability of tragedy as a historical source for funeral practice has quite rightly been called into question. Helene Foley, in her study of women in tragedy, considers 'tragedy's relation to its historical context to be general and

\footnotetext{
${ }^{22}$ This will be looked at more closely in Chapter One and the discussion of the post aliquanto law.

${ }^{23}$ Bruss (2005) 11; Morris (1992) 156.

${ }^{24}$ Oakley (2004) 231.

${ }^{25}$ Whether the lekythoi represent everyday scenes, scenes from poetry or tragedy, or the painter or patron's idealised conception of the grave will be looked at more closely in Chapter Two.
} 
oblique rather than topical or allegorical ${ }^{26}$ and argues that tragedy gives a voice to those who are usually silent in the political arena (women, slaves and foreigners). She is clear to state that 'we do not expect from tragedy any direct reflection of contemporary Athenian social practice. ${ }^{, 27}$ Kerri Hame, who looks closely at funeral rites in the Oresteia, picks up this notion. She demonstrates that the tragedians manipulated and altered funeral rites, frequently using Homeric and mythical themes and including anachronistic rites. ${ }^{28}$ Death also featured in Attic Old Comedy. Aristophanes exploited it for comic effect. In the Frogs (414 B.C.E.) Aristophanes mocks attempts by relatives or friends to claim the privilege of burial in the Kerameikos (see Chapter Three for further discussion of this scene). Two of his other works, Knights (424 B.C.E.) and Clouds (423 B.C.E), also provide evidence of attitudes towards death. As with tragedy it is necessary to keep in mind the motivations of the author and what point, tragic or comic, they are making.

From the Classical period come the main surviving prose works: Herodotus' Histories (440 B.C.E.), Thucydides' History of the Peloponnesian War (431 B.C.E) and various works from fourth century philosophers. Herodotus, in writing his Histories, travelled extensively and often compared Greek practices to those of other cultures. For instance, in book four he outlines the burial practices of the Issedonians and compares them to those of the Athenians (4.26). He provides one of the few references to the Athenian Genesia, a probable state

\footnotetext{
${ }^{26}$ Foley (2001) 27.

27 Ibid.

${ }^{28}$ Hame (2004) 514. n.4.
} 
festival held in honour of the state dead. ${ }^{29}$ Thucydides' work provides perhaps the most famous epitaphios logos, a funeral oration given by Pericles. ${ }^{30}$ The philosophers also discuss funerals in their works: Plato's Laws 959D - 960C gives an outline of how Plato thinks the funeral should be conducted, and Plato's Menexenus contains the (facetious) claim that Aspasia actually wrote Pericles' funeral oration (235E ff.). ${ }^{31}$

Law court speeches also provide much information about death in the Classical period. These speeches date to the late Classical period but still provide nearcontemporary evidence of concerns within Athens. Many cases came before the courts concerning inheritance. At these trials speeches were given, with the most useful being those of Lysias and those attributed to Demosthenes. As a by product these speeches provide indirect evidence concerning funerals and funerary practices, for example Lysias claims that 2500 drachmae were spent on one tomb, a figure that was probably exaggerated for persuasive effect (32.21). There is, however, a difficulty involved in using Attic law court speeches as a historical source because they were written in order to persuade a jury and consequently contain an inherent bias.

\footnotetext{
${ }^{29}$ The Genesia is connected with the state appropriating private rites, and utilising them to promote the polis. It will be addressed more thoroughly in Chapter Two.

${ }^{30}$ There is much debate about this epitaphios logos, which will be dicussed more closely in Chapter Two. I view the oration attributed to Pericles as perhaps more a reflection of Thucydides' own thinking than Pericles', but nonetheless it is a good example of an epitaphios logos and provides a format and sentiment that is consistent with other recorded orations, and probably reflects the opinion of the day regarding death. For further discussion see Bosworth (2000) $1-16$.

${ }^{31}$ Ochs (1993) 68; Frangeskou (1999) 316.
} 
This study, of such varied and disparate sources, is divided into three parts. Chapter One outlines exactly what the changes in funeral practice were between the Archaic and Classical periods. It will focus on the decline of grave markers, the shift to extra-mural burial, the change in how funerals and death were depicted, the increased emphasis on state burial and the change in both public and private mourning practices around 480 B.C.E., ${ }^{32}$ arguing that there was a definite change in how the Athenians interacted with their dead, both physically and ideologically.

Chapter Two examines the reasons behind the change in burial practices around 480 B.C.E. It was a complex change, and therefore it is highly improbable that it had simple factors or motivations behind it. To ascribe the change to a single catalyst, such as Richter does when she puts forward the Persian wars as the sole cause, is naïve. Other arguments have been put forward, such as a lack of space, or a change in fashion, ${ }^{33}$ but these fail to take into consideration the complex changes that Athenian society was undergoing. The most likely cause of such a shift in attitude is a combination of complex reasons, where a few predominate, such as appropriation of death by the polis resulting in glorified state burials and development of democracy. ${ }^{34}$

Chapter Three examines the re-emergence of grave monuments. The archaeological record reveals a reappearance of stone funerary sculpture a

\footnotetext{
${ }^{32}$ Grave stelae did not completely disappear; some families ignored the trend and continued to erect them (see p. 36). Garland (1989) 6; Morris (1992) 132.

${ }^{33}$ Cannon (1989) esp. $444-446$.

${ }^{34}$ It is unclear whether a developing democracy led the state to appropriate death or whether the appropriation of death developed democracy. This issue will be explored further in Chapter Two.
} 
decade or so after the middle of the fifth century (c. $440-430$ B.C.E.). ${ }^{35}$ Multiple reasons have been suggested, but it will be the contention of this chapter that the re-emergence of funeral sculpture was influenced heavily by foreign workers who brought with them their own burial practices which in turn inspired Athenian aristocrats to re-appropriate death and begin erecting private funeral monuments, however instead of only using Homeric imagery, as they had in earlier periods, they appropriated state symbols and incorporated them into private monuments.

\footnotetext{
${ }^{35}$ Leader (1997) 101.
} 


\section{The Change in Burial Practices Between the Archaic and Classical Periods}

There was a definite change in how the Athenians interacted with their dead, both physically and ideologically, at the turn of the Classical period. ${ }^{36}$ In the absence of consensus regarding the date, nature, and reason for the perceived transformation of burial practices, this chapter will outline exactly what the changes in funeral practice were between the Archaic and Classical periods. It will focus on the decline of grave markers, the shift to extramural burial, the change in how funerals and death were depicted, the increased emphasis on state burial and the change in both public and private mourning practices around 480 B.C.E. ${ }^{37}$

Scholars have stated that there was a change in funeral practices and ideology in Athens between 530 and 480 B.C.E. Those who have written on the topic often mention in passing that a change did occur and proceed to study the change utilising limited sources, ${ }^{38}$ an approach which has led to divided opinions. John Boardman and Donna Kurtz, for example, list possible reasons for a shift in burial practices but draw no conclusions. ${ }^{39}$ Karen Stears argues that political developments produced the change in constraints upon burial and

\footnotetext{
${ }^{36}$ To date, studies have been too narrow, in that they tend to focus on one source of evidence, such as Toher and Garland who focus on funerary legislation. Toher (1991) $159-60$; Garland (1989) $1-15$.

${ }^{37}$ Grave stelae did not completely disappear; some families ignored the trend and continued to erect them. Garland (1989) 6; Morris (1992) 132.

${ }^{38}$ Boardman and Kurtz (1971) 89 and Garland (1989) 1 both mention the change in passing. Richter (1971) and Stears (2000) 25 - 58, examine the change through a study of the archaeology; Garland (1989) $1-15$, and Toher (1991) 159-175 focus on the laws.

${ }^{39}$ Boardman and Kurtz (1971) 89 - 90, provide a brief discussion of Cicero's post aliquanto law but conclude that they do not know whether the decline of funerary monuments was due to natural causes, such as a lack of space, or contemporary political, social, and economic conditions. On page 121 they then write that the halt in gravestone production was 'probably as a result of the legislation recorded by Cicero in the Laws.'
} 
commemoration, citing 'the growing egalitarianism of the first decades of the century. ${ }^{40}$ Deborah Kamen argues along similar lines, contending that the reason behind the change was a 'burgeoning egalitarian ideology', ${ }^{41}$ which among other factors, pressured elites 'to conform to the new ideology to which the majority of the population adhered. ${ }^{42}$ Nicole Loraux argues that the power of the monument and the glory of the war dead were taken over by the polis as part of the formation of a civic ideology provided by the state. ${ }^{43}$ Her study is restricted to literary evidence, in particular the epitaphioi logoi, which makes her analysis static and misses trends present in archaeology. Gisela Richter, in her study of grave stelae, briefly addresses the change in practice and attributes it in the main to the Persian Wars. ${ }^{44}$ John Oakley in his analysis of lekythoi dates the change to 480 B.C.E. linking it to the establishment of the Demosion Sema and the institution of the state funeral for those who died in battle. ${ }^{45}$

Other scholars argue for a broader picture and continual processes. Ian Morris looks closely at the trend of restraint, and places it in a Panhellenic context. He argues that relative display of wealth declined between 500-425 B.C.E. throughout Greece, drawing parallels between Athens and Thessaly, Lycia and

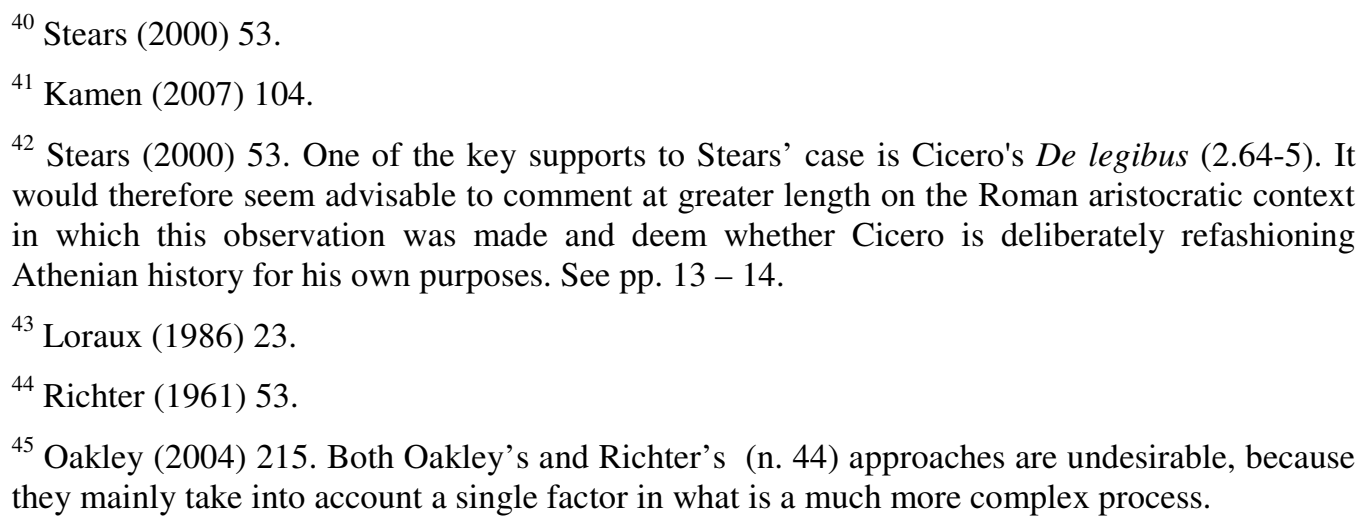
would therefore seem advisable to comment at greater length on the Roman aristocratic context in which this observation was made and deem whether Cicero is deliberately refashioning Athenian history for his own purposes. See pp. $13-14$.

${ }^{43}$ Loraux (1986) 23.

${ }^{44}$ Richter (1961) 53.

${ }^{45}$ Oakley (2004) 215. Both Oakley's and Richter's (n. 44) approaches are undesirable, because they mainly take into account a single factor in what is a much more complex process. 
Macedonia among others. ${ }^{46}$ Aubrey Cannon also subscribes to the idea of a Panhellenic trend, viewing it as part of a larger historical process in Greece, which he terms 'expressive redundancy.' ${ }^{47}$ Expressive redundancy explains the cyclical nature of mortuary expression in terms of maintaining visible differentiation between the various levels of a social hierarchy, where often, according to Cannon, restraint in expression starts first amongst the elite as a way to differentiate themselves from the masses. ${ }^{48}$ Mark Toher too uses a Panhellenic approach, but focuses solely on funerary laws, both Athenian and those from other Greek poleis, showing that the laws share some common characteristics, which he argues supports a possible Panhellenic trend. ${ }^{49}$ Richter and Friis Johansen both describe how stelae appeared suddenly in other poleis just as they disappeared in Athens. ${ }^{50}$ Morris, therefore, contradicts both Richter and Johansen when he argues for a Panhellenic decline in funerary sculpture. $^{51}$

\footnotetext{
${ }^{46}$ Morris (1992/3) 41. In Thessaly the bulk of the grave sculptures date to this period. Richter (1961) 54 argues that Thessalian stelae flourish whilst Athens declines, which Morris accepts, but compared to what came before and after, the mid-fifth century in Thessaly was restrained. A trend of declining funerary monuments is also seen in Lycia, where the local tradition of rockcut tombs is suppressed for about 75 years, until reappearing with the Xanthos cemetery around 400. In Macedonia, the great Archaic tumuli largely disappear around 500, and the earliest forms of Macedonian vaulted tombs appear after 400. Sparta is the exception, where burials elude us entirely. Morris (1992/3) 41.

${ }^{47}$ Cannon (1989) 447 : See also the Bryn Mawr review of Ian Morris' 'Death-Ritual and Social Structure in Classical Antiquity.' by James C. Wright. (04.02.08) as it provides a good summary of the approaches taken to the study of law.

${ }^{48}$ Ibid.

${ }^{49}$ Toher (1991) 159 - 175; Also see Seaford (1995) 74 - 86; Garland (1989) 1 - 15. Blok (2006) 241 argues that there cannot have been a single legal impetus in one polis behind an overall change. The laws are fully recorded in Appendix 1.

${ }^{50}$ Richter (1961) 54; Johansen (1951) 122.

${ }^{51}$ Morris (1992/3) 41.
} 
The law that draws the most attention, and perhaps most clearly demonstrates how complex this transitional period is, is the post aliquanto legislation referred to by Cicero in his De Legibus (2.64). ${ }^{52}$ Cicero records that this legislation was introduced 'sometime after' Solon, hence the name, and was concerned with regulating the size and style of tomb monuments (Appendix 1: 4c). The connection between the decline in the Athenian monuments and the law was first made by Milchhöfer in 1880 and was accepted as recently as 1989 by Robert Garland. ${ }^{53}$ Richter dates the legislation to around 530-525 B.C.E, during Peisistratus' time, citing Plutarch's statements that 'Peisistratos retained most of Solon's laws... and also made other laws himself,' and that 'Theophrastos writes that the law against idleness... was made not by Solon, but by Peisistratos' (Plutarch, Solon. 21 (Appendix 1: 3)) ${ }^{54}$ Richter links the law to a simplification in Attic grave stelae in the last third of the sixth century rather than their disappearance around 480 B.C.E. ${ }^{55}$ The law has also been dated to the rule of Cleisthenes (c. 507/8) ${ }^{56}$ supporting Milchhöfer and Garland, but some, such as Verena Zinserling and Stears, date the law somewhat differently, to 487 B.C.E. and c. $480 / 79$ B.C.E respectively. ${ }^{57}$ Stears suggests the law was an idea put forward by Cimon as an act of 'cryptophilolakonism', as the Spartans were known for their restraint in burial practices, and thus the passage of the law could have indicated that the Athenians were attempting to align themselves

\footnotetext{
${ }^{52}$ Boardman and Kurtz (1971) 121.

${ }^{53}$ Milchhofer, (1880) 172 cited in Garland (1989) 6.

${ }^{54}$ (trans. Richter (1945) 152); Richter (1961) 39; Boardman (1955) 53 concurs with Richter on the dating the law to the rule of Peisistratus but gives little explanation as to why.

${ }^{55}$ Richter (1961) 38.

56 Johansen (1951) 120.

${ }^{57}$ Garland (1989) 6; Zinserling (1965) 29 - 31 cited in Clairmont (1970) 11 - 12; Zinserling was the first to link the law with Themistocles.
} 
with Spartan practices. ${ }^{58}$ Angeliki Kosmopoulou argues that Themistocles introduced the law in the first decade of the fifth century and links the law with the change in how the dead were honoured: the shift from private to public mourning. ${ }^{59}$ Christoph Clairmont prevaricates, suggesting 'the decree may have been seriously envisaged by Cleisthenes, but enforced only by the more radical later statesman Themistocles, ${ }^{60}$ whilst Josine Blok argues that the post aliquanto law is 'a historical anomaly' and 'that its existence is an erroneous conjecture of our sources. ${ }^{, 61}$ The most accepted date is c.470/460 B.C.E. ${ }^{62}$ The issue is further confused due to Cicero's terminology; the term post aliquanto is vague and ambiguous making it difficult to date the law - would Cicero have considered 100 years as 'somewhat later' than Solon ${ }^{63}$ This law is the most cited piece of evidence for the change in burial practices. However modern scholarship has granted it undue weight - it is unlikely a single, otherwise unattributed, law brought about such a dramatic change in funeral practice. This law and the problems surrounding interpretation of it provide clear evidence of how complicated these changes in Athenian burial practices were.

\footnotetext{
${ }^{58}$ Stears (2000) 53.

${ }^{59}$ Kosmopoulou (2002) 44.

${ }^{60}$ Clairmont (1970) 11.

${ }^{61}$ Blok (2006) 242 argues that the law can at best be situated in the later fourth century B.C.E and that later writers have wrongly attributed it. She questions the reliability of both Cicero and his source, Demetrius of Phaleron.

62 Ibid.

${ }^{63}$ Dyck (2004) 415; post aliquanto is ambiguous and defines an unspecified length of time, which has resulted in the law being dated to varying decades. Boardman and Kurtz (1971) and Small (1995) both refer to the law as post aliquando, though the meanings of aliquanto and aliquando are much the same in this context.; Blok (2006) 241.
} 


\section{The Archaic Funeral}

In order to demonstrate that a change in funeral practice and ideology occurred it is necessary to initially outline Archaic Athenian practices. Alan Shapiro demonstrates that the Archaic funeral was a grand affair, evidenced by epic poetry, pottery, archaeology, epigraphy, later historical sources and surviving artworks. ${ }^{64}$ The tripartite structure of the funeral had long been established in Ancient Athens. The funeral began with the prothesis, where the body was cleaned and then laid out on a table or klinē - relative to the status of the deceased - to be viewed by the mourners. This could be a protracted event: in the Odyssey seventeen days are devoted to the obsequies for Achilles (Od. 24.63 - 6), and in the Iliad nine for Hector (Il. $24.664-665$ ), and two for Patroclus (Il. $23.54-55){ }^{65}$ The funeral process was chiefly carried out by women, as shown by prothesis depictions on Geometric vases (Appendix 2: Fig. 1), and those present at the funeral of Hector (Il. 24. $710 \mathrm{ff}$.). The second part of the funeral was the ekphora. The men led the procession of the body through the streets. It was either transported on a cart pulled by horse or carried by pallbearers. Female mourners followed behind the procession. ${ }^{66}$ The procession was noisy and held during the day causing significant disruption within the polis. $^{67}$

\footnotetext{
${ }^{64}$ Shapiro (1991) $631-632$.

65 The funerals of Achilles, Hector, and Patroclus are larger than life heroic funerals. Presumably the prothesis was never that protracted in "real life" due to decomposition (However, in the Iliad the gods step in to halt this process; for futher discussion see Segal (1971). The Epic length is probably symbolic - note how the "better" heroes have more days devoted to their funerals. That Solonian law expressly prescribed a single day for the prothesis, however, does imply that prior to the legislation the prothesis was an extended event. Garland (2001) 26.

${ }^{66}$ Solonian legislation limited who could attend a funeral, but prior to these laws it seems as if anyone wishing to pay their respects was able to attend.

67 Kamen (2007) 103; This is indicated by Solonian law which legislates against hiring mourners and that the ekphora must take place before sunrise.
} 
Once at the cemetery, or burial place, the final part of the funeral saw the inhumation or cremation of the body, with grave goods placed in or near the grave and sacrifices performed. ${ }^{68}$ The women sang laments and dirges during the funeral process, as well as tearing their cheeks, baring their breasts, and cutting their hair to express grief. ${ }^{69}$ Women would return first to the oikos, perhaps to prepare the funerary meal (perideipnon) ${ }^{70}$ the men would follow later having attended to the grave. ${ }^{71}$ The mourners may have returned to the gravesite to carry out the third (ta trita) and ninth (ta enata) day rites. ${ }^{72}$ A feast was held on the thirtieth day (triakostia) marking the end of the mourning period. $^{73}$ The funeral of an aristocrat or wealthy individual could be followed by funeral games (agones), similar to those held for Patroclus in Iliad $23 .^{74}$ The grave marker was placed in a cemetery or along the roadside, serving as a symbol of the wealth, status and power of both the deceased and the deceased's family.

\footnotetext{
${ }^{68}$ In the Iliad cremation is the only form of burial, but in reality inhumation and cremation were used concurrently and it seems to have been a matter of personal choice : Patterson (2006b) 11 argues that Greeks and Athenians spoke of tombs, not of cemeteries. She is correct in that in Athenian reality tombs stood along roadsides and that the term cemetery is used from a modern perspective. Her stance is evidenced by the words of Pausanias. Pausanias describes burials as being placed along the course of the Academy Road (1.29.2).

${ }^{69}$ Holst-Warhaft (1992); Sourvinou-Inwood (1995) 33. Lament has a long history in the Greek tradition and seems to have taken on a regulated form. Perhaps the most well known laments are those from the Iliad, where Helen (24. 762 - 75), Hecuba (24.748 - 59) and Andromache (24.725 - 45) lament over the body of Hector. See Alexiou (2002) $133 \mathrm{ff}$. for further discussion on the lament in Greek tradition and the rituals surrounding it.

${ }^{70}$ Burket (1985) 193; Albinus (2000) 30.

${ }^{71}$ It is not clear what the men did at the grave, but it is possible that they constructed the tomb or completed the burial.

${ }^{72}$ Kamen (2007) 104; Hame (2004) 529 - 530.

${ }^{73}$ Burket (1985) 194.

${ }^{74}$ For further discussion on the funeral see Garland (2001); Burkert (1985) 190 - 194; Stears (1998) 113 - 127; Small (1995) 144 - 145; Ochs (1993) 41 - 60; et al.
} 


\section{Panhellenic Trend}

A Panhellenic trend of restraint seems to have occurred at the same time as funerary monuments declined in Athens. This poses somewhat of a quandary, as it is nearly impossible to tell if the trend started in Athens and then spread or whether the trend started elsewhere and then found its way to Athens. The Cean laws are a good example of this problem. The Cean law code dates to the second half of the fifth century B.C.E. but may record an earlier law. ${ }^{75}$ It shares many similarities with Solonian legislation - perhaps the most important similarity is that both have the same aim: to prevent the death of a member of one's family from being exploited for political effect. ${ }^{76}$ Which of the law codes came first is hard to establish. Solon's legislation is dated to 594/3 B.C.E., the year of his archonship, but the major funeral restrictions took place some one hundred years later when we have evidence of more funeral legislation being introduced in the form of the post aliquanto law. During this era of funeral legislation Athens and Ceos shared close ties and it is therefore possible that Athenian legislation concerning funerals influenced Cean Law or vice versa. ${ }^{77}$

Morris champions the argument that restraint was a Panhellenic phenomenon. ${ }^{78}$ This thesis is concerned with the change in Athenian practices, but I will briefly discuss other poleis here. There were contingent similarities between law codes in various poleis, but such small points of contact do not add up to a Panhellenic

\footnotetext{
${ }^{75}$ Blok (2006) 211.

${ }^{76}$ Garland (1989) 12.

${ }^{77}$ Thucydides reports that Athens and Ceos were both members of the Delian League. (2.9) cf. Blok (2006) 212 who does not agree that Athenian laws influenced those of Ceos, as she contends the law of Ceos predates the Delian league.

${ }^{78}$ Morris (1992) 146.
} 
trend. Morris implies that there was a mentality that started somewhere and spread throughout Greece, when it is possible that the same change was occurring for different reasons. ${ }^{79}$ The theory of the Panhellenic trend does not explain why those changes happened in the first place, regardless of how they might have spread. A definite rationale for a change in Athenian practices needs to be offered and explanations for other poleis need to be argued before a Panhellenic trend can be proven. As it stands, Athens provides the most evidence and had her own internal dynamics; therefore an Athenocentric analysis is the best place to start.

The lavish funeral was typical of many early Greek states. Even Sparta, known for its restraint in burial practice, provides evidence of lavish funerals in the Archaic period. Tyrtaeus in the late seventh century B.C.E gives an impression of visible funeral rites: ' ...they bewail their masters, they and their wives, / when the mournful fate of death strikes one of them.' (Frag. 7). ${ }^{80}$ The implication is that more prosperous landowners would receive a grander sendoff from a larger crowd of mourners than less wealthy citizens. In Sparta it seems such lavish events were reined in by Lycurgus who removed superstition from burials by allowing intramural burial, banning grave goods and forbidding the grave marker to be inscribed, unless the deceased had died in battle (Plutarch Lycurgus 27.1-2 and Instituta Laconica 238d (Appendix 1: 10 and 11)). ${ }^{81}$ Evidence indicates that after 550 B.C.E Spartan funerals became more

\footnotetext{
${ }^{79}$ Ibid.

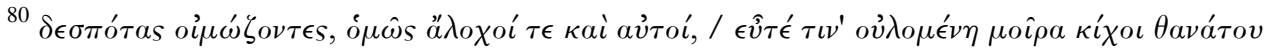
(trans. Hodkinson (2000) $237-8$ )

${ }^{81}$ Seaford (1994) 76; Both accounts bear obvious resemblances, and although post-classical their accounts are in line with archaeological evidence: both make reference to intramural burial
} 
restrained than in preceding centuries and therefore, according to Hodkinson, that the laws of Lycurgus had an effect. ${ }^{82}$ It is also possible that Lycurgus was codifying social change that was already happening in Sparta. As a result of the ban on grave goods, no burials have yet been identified in Sparta that are definitely datable to between 550 and 200 B.C.E. ${ }^{83}$ Other poleis also had legislation concerned with ostentatious funerals: such legislation has predominantly been found in Gortyn, Ceos, and Delphi.

Delphi had the Regulation of the Labyadai set down by the phratry of the Labyadai c. 400 B.C.E. The regulations appear on a large inscription. The inscribed regulations governed the celebrations of religious festivals, and included a section concerning funerals and regulations surrounding them (Appendix 1: 7). The regulations limited expenditure and display, both in the number of garments a body could be buried in, and also by stating that the covered body must be carried in silence and that there must be no wailing outside the house before arrival at the grave nor the singing of dirges. Although the law was established by the religious group, the Labyadai, it may well have emanated from state authority. ${ }^{84}$ It parallels other laws from the region making it a valuable piece of evidence for a Panhellenic trend or at least highlights how central the funeral was to everyday life in Greece. ${ }^{85}$

and there is evidence of burials in the vicinity of Spartan villages during pre- and post-classical periods. Hodkinson (2000) $244-5$.

${ }^{82}$ Ibid, 243.

${ }^{83}$ Ibid.

${ }^{84}$ Seaford (1994) 78.

${ }^{85}$ Rhodes and Osborne (2003) 8 - 9 . 
An inscription from Iulis in Ceos (Appendix 1: 8a and 8b) enacted regulations similar to the Solonian laws of Athens. ${ }^{86}$ The Cean code has been dated to the second half of the fifth century B.C.E. but on the basis of the language and lack of a prescript it is generally agreed that the inscription preserves much earlier legislation. ${ }^{87}$ The prothesis is not mentioned in the inscription; the law begins with the preparation of the body for the ekphora and detailed instructions for the funeral procession itself. The inscription then prescribes what can happen after the funeral, and cuts off while disclosing the procedure of purification for all mourners. ${ }^{88}$ The law limited the number of women who could go into mourning, banned lamenting during the ekphora, and placed a limit on how much could be spent on the garments of the dead individual. ${ }^{89}$ Gortyn too had regulations relating to the treatment of the dead. Unfortunately only two fragments have survived, both of which date to between 500-450 B.C.E. (Appendix 1: 9a and 9b.). ${ }^{90}$ The first deals specifically with the ekphora and the second with ritual purification after death.

There is also limited evidence of funeral law from other poleis. At Katane the lawgiver Charondas (from the second half of the sixth century B.C.E.) declared that the dead should not be honoured with tears and lamentations, but with a good memory and seasonal offerings (Stob. Flor. 44.40). ${ }^{91}$ Pittacus of Mytilene (c. 650-570 B.C.E.) forbade the practice of attending the funerals of others (Cic.

\footnotetext{
${ }^{86}$ Toher (1991) 164; There is one major difference between the laws of Ceos and those of Solon: the Cean law specifically treats the question of purity. Parker (1983) 35.

${ }^{87}$ Seaford (1994) 77; Toher (1991) 165.

${ }^{88}$ Toher (1991) 165.

${ }^{89}$ Simms (1997/8) 135.

${ }^{90}$ Frisone (2000) 25.

${ }^{91}$ Stob. Flor. 44.40 cited in Seaford (1994) 77.
} 
De Leg. 2. 66). At Syracuse Gelon kept to the detailed pre-existing law passed by the Syracusans forbidding great expense on the dead (Dio. Sic. Bib. Hist. 11.38). In Rome the funerary law in the Twelve Tables (mid-fifth century B.C.E.), as detailed by Cicero, limited expenditure and mourning (De Leg. $2.59) .^{92}$

That lawmakers across the Greek world needed to introduce legislation to deal with funerals provides two important pieces of information. Firstly, by looking at what was prohibited we can draw inferences about funerals before the legislation, and secondly, we can see that some sectors of society felt that funerals were becoming too ostentatious and that they saw the need to legislate in order to control funerals. This need to legislate is no more apparent than in Athens. Athenian funeral laws are addressed later in this chapter, however tradition has it that Solon was brought in to reconcile Athens, which was on the brink of "civil war" (Solon fr. 4.5-15).$^{93}$ As part of his mandate he brought in many laws, some of which were directed at funerals, in particular the behaviour of women. These laws highlight that there was a change in both funeral practice and ideology.

Morris claims that these laws reflect a Panhellenic effect, which to a degree is borne out by the archaeological record. ${ }^{94} \mathrm{He}$ argues that there was a decline in funerary sculpture around 500 B.C.E. throughout Greece, even in rather

92 Seaford (1994) 76-77; The sources we have for funeral legislation are a lot later than the legislation itself and therefore their reliability is questionable (and therefore might reflect a similar situation to the Athenian legendary/ 'real' Solon and his laws).; Also see Simms (1997/8) 134. n. 57.

${ }^{93}$ Lape $(2002 / 3) 117$.

${ }^{94}$ Morris (1992) 145. 
peripheral areas: the great tumuli at Vergina and Trebenishte cease to be built, and the Lycian series of rock-cut tombs breaks off, although a few podium tombs in the Persian tradition continue. ${ }^{95}$ A handful of chamber tombs on Aegina date around 450 B.C.E., and several relief stelae and small block gravestones have turned up around the Aegean and in Boeotia. ${ }^{96}$ Richter discusses many other poleis where stelae appear without any previous tradition, including Thessaly, Thrace, Akarnania, Delphi, Boeotia, Megarid, Laconia; and in the islands of Samos, Syme; and in Apollonia, South Russia and Italy. ${ }^{97}$ However, Morris accepts that the only good high quality series of stelae at this time are from Thessaly, which flourishes just as Athenian stelae become rare. ${ }^{98}$

The stelae of other poleis are invariably of the type that evolved in Attica during the late sixth century. ${ }^{99}$ It is probable that Attic sculptors left Athens, relocated to other poleis and plied their trade there. ${ }^{100}$ This Panhellenic spread of stelae goes against Morris' theory of restraint. Morris argues that the Athenian phenomenon needs to be viewed and analysed in conjunction with the Panhellenic evidence, ${ }^{101}$ including the legislation passed in other areas of Greece. Elizabeth Meyer sees a similar pattern: that the fifth century was a period of restraint in burial and of commemoration in most Greek city-states,

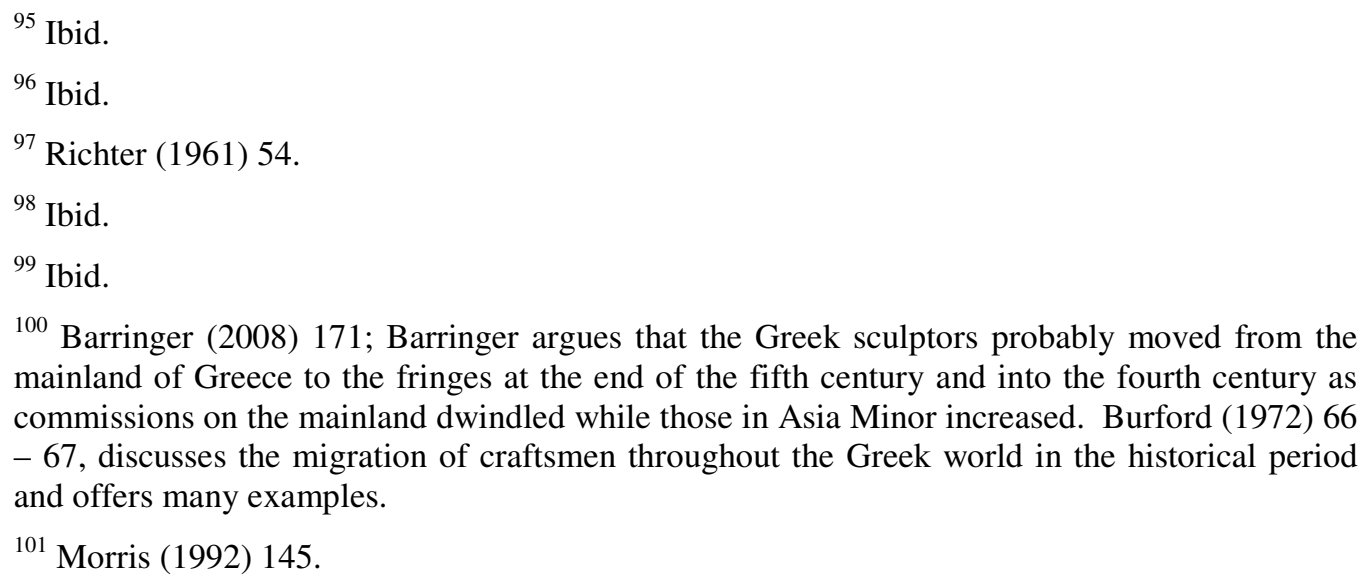
mainland of Greece to the fringes at the end of the fifth century and into the fourth century as commissions on the mainland dwindled while those in Asia Minor increased. Burford (1972) 66 - 67, discusses the migration of craftsmen throughout the Greek world in the historical period and offers many examples.

${ }^{101}$ Morris (1992) 145. 
and that the fourth century was one of lavishness. She then goes on, however, to argue that Athens was in many ways an unusual polis and followed this general pattern for its own unique reasons, and in its own distinctive way; therefore the Athenian situation is inimitable enough to be studied in isolation. $^{102}$ I am not convinced that we should be looking outside Athens to explain Athenocentric trends. Comparative evidence has a role as shown above, but the most important evidence for Athens is that from within Athens itself and therefore we should, as Stears demonstrates, look more at the internal trends within Athens: trends such as changes in votive offerings which bear an inverse relationship to grave markers. ${ }^{103}$

\section{Grave Markers}

The Athenian archaeological record, in the form of stelae, kouroi, korai, earth mounds, grave goods and the graves themselves, provides the most obvious evidence for changes in funeral practices between the Archaic and Classical periods. The Attic stelae, which appeared in Attic cemeteries in the late seventh century and throughout the sixth century B.C.E., are impressive, high quality, and expensive monuments which marked the graves of the Athenian elite. ${ }^{104}$ These stelae consisted of a decorated shaft, a surmounting finial, and a rectangular base. The stelae can be divided into two sequences, each with three

\footnotetext{
${ }^{102}$ Meyer (1993) 119.

${ }^{103}$ Stears (2000) 46.

${ }^{104}$ Boardman and Kurtz (1971) 89; Stears (2000) 29. Some are of exceptional quality: notably the kouros of Aristodikos (IG $\mathrm{I}^{3} 1244$, Athens NM 3938 c. 500 - c. 490 . B.C.E) and the stele of Antigenes ( $I G \mathrm{I}^{3} 1276$, MM NY 15.167 c.510 - c. 500.) In this period sepulchral and votive stelae had the same forms, so it is not always certain which purpose fragmentary examples served when their finding places are not known; Richter (1961) vii. I have made every effort to limit this study to those known to be grave stelae.
} 
subdivisions. ${ }^{105}$ The earlier type, prevalent between $610-530$ or 525 B.C.E., had a capital carved in a separate piece from the shaft, and was surmounted by a sphinx, which was mostly carved from a separate piece of marble. The capital was first of the cavetto form derived from Egypt; later it was of a 'lyre' design from Ionia. ${ }^{106}$ In both cases the shaft was regularly decorated with a depiction of the person commemorated, and mounted on a rectangular base. The dedication was inscribed on the base or, more rarely, on the stele itself. ${ }^{107}$ Some time after the middle of the sixth century the impressive monuments (Appendix 2: Fig. 2: I a, b, c) were simplified (Appendix 2: Fig. 2: II a, b). The sphinxcapital was converted into a palmette surmounting a pair of volutes; the stelae were carved in one piece. ${ }^{108}$ The second type continues, albeit in fewer numbers and an even simpler form, into the fifth century (Appendix 2: Fig. 2: II c). There was a sharp decrease in production around 480 B.C.E.: the authors of the Inscriptiones Graecae list only 45 inscribed sepulchral monuments possibly dating to between c.510-c.480 B.C.E. ${ }^{109}$ Sculpted funerary monuments did not reappear en masse until some time in the third quarter of the fifth century. ${ }^{110}$

Archaic monuments like kouroi or figured grave-stelae are thought to attempt a generic representation of the deceased: not a specific representation of a specific person but a representation of what type of person the deceased was, generally

\footnotetext{
${ }^{105}$ Richter (1961) 2.

106 Ibid.

${ }^{107}$ Ibid. Inscriptions on Attic gravestones were normally short, giving only essential details: the name of the dead person, those who mourn him, those who erected the monument in his honour. Boardman and Kurtz (1971) 86.

${ }^{108}$ For a much more detailed account of individual stelae see Richter (1961) 8 - 37.

${ }^{109} I G \mathrm{I}^{3}$.

${ }^{110}$ Stears (2000) 26 - 27; Richter (1961) 53; Morris (1992) 128 - 9. See Chapter Three for further discussion.
} 
giving them the attributes of the eternal and universal aristocracy of the best men. ${ }^{111}$ When these monuments have epigrams, the epigram stresses these aristocratic virtues. Joseph Day has concluded that these 'verse inscriptions and grave markers not only communicate the same message of praise, but do so in a formally parallel manner', a parallelism attributed 'to their common function of memorializing and re-enacting funerary ritual. ${ }^{112}$ Again the early importance of the funeral is emphasised. The monument focussed attention on how the deceased had been honoured by (preferably large numbers of) people, and encouraged those who did not know him or her, who learned about his or her funeral and aristocratic virtues through the tomb and marker, to honour the deceased as well. ${ }^{113}$

Burial was not limited to the elite, yet it is a long-standing assumption that any surviving grave marker in Athens was that of an Athenian aristocrat. ${ }^{114}$ A clay plaque (Appendix 2: Fig. 3) or a loutrophoros (Appendix 2: Fig. 4) marked more modest graves of both men and women in Archaic Athens. ${ }^{115}$ These provide the clearest pictorial evidence of how average Athenians mourned their dead. ${ }^{116}$ The vast majority of scenes depict the prothesis. ${ }^{117}$ Since the elaborate Geometric style ekphora (Appendix 2: Fig. 1) was probably banned (due to the

\footnotetext{
${ }^{111}$ Stewart (1990) 109 - 110; For parallels in encomia of the dead see Thomas (1989) $103-4$.

${ }^{112}$ Day (1989) 16; cf. Svenbro, (1993) 13 - 18 on oral kleos (renown).

${ }^{113}$ Meyer (1993) 107.

${ }^{114}$ Davies (1984) 267, only foreigners are mentioned.; Osborne (1985) 135; Garland (1987) 66, foreigners only.

${ }^{115}$ Shapiro (1991) 633.

${ }^{116}$ It is always necessary to be cautious when looking at art. Taking art as a straightforward, transparent representation of reality, especially with respect to a topic like death, is inadvisable. Ideals come into play: what we are viewing is an idealised picture of death, not an individual; nonetheless we still see the perceived view of death in Ancient Athens at the time of painting.

${ }^{117}$ Shapiro (1991) 633.
} 
laws of Solon), the emphasis in art shifted to private lamentation at home. ${ }^{118}$ The gatherings depicted on the loutrophoroi and plaques are smaller than those previously depicted on the geometric vases, and clearly indicate a close family group (Appendix 2: Fig. 3 and Fig. 4). ${ }^{119}$ This reduction in size could be due to Solon's funeral laws or simply because there is less room for images on a plaque compared to earlier geometric vases. ${ }^{120}$ Loutrophoroi were still made, in black-figure and later in red-figure, but after about 470 B.C.E. become uncommon. ${ }^{121}$ The funerary plaque, or pinax, ceased production by 480 B.C.E. and never made the transition to the red-figure technique. ${ }^{122}$ The plaques can be divided into two groups, those which were complete in themselves and those which formed part of a larger series. ${ }^{123}$ Series plaques, which were roughly uniform in size and shape, are known from just before the end of the seventh century to about 530 B.C.E. No plaques have been found in situ, nor is it clear how they were attached to tombs, but it is possible they were set into the tomb walls. ${ }^{124}$ These plaques were painted by the most accomplished painters of the period such as Sophilos, Lydos, and Exekias, and have been found in Athens, Kalyvia Kouvara, and Sparta. ${ }^{125}$ The single plaques follow on chronologically from the series plaques and were much smaller. They were pierced for suspension or nailing and disappeared around the end of the fifth century

${ }^{118}$ Ibid.

${ }^{119}$ On a plaque by Exekias the figures present at the prothesis are labelled, and all fall within second cousin, as the laws of Solon decreed they should. It is not clear whether it is a representation of an ideal or what really happened.

${ }^{120}$ Shapiro (1991) 631.

${ }^{121}$ Ibid.

${ }^{122}$ Boardman and Kurtz (1971) 83 say that plaques ended in Athens about 530 B.C.E.

${ }^{123}$ Boardman (1955) 53.

${ }^{124}$ Ibid, 52. See full article for a more detailed discussion of funerary plaques.

${ }^{125}$ Boardman and Kurtz (1971) 83. 
B.C.E., although there is no indication of change in the built tombs on which they were hung and which continue into the Classical period. ${ }^{126}$ The poor also buried their dead, but their graves are lost from the archaeological record.

Amongst all the evidence of decline, a few monumental tombs dating 500 - 425 B.C.E. have been identified, covering at least two sequences. It is likely there were families who for three generations ignored the move towards restraint, rather than a handful of eccentrics setting up tasteless tombs. ${ }^{127}$ The most important exception to sepulchral restraint was found in the Kerameikos, within sight of the Demosion Sema where state funerals took place. The large mound G of 560 B.C.E. was followed over the next fifty years by eleven shaft graves and, on its west edge, two smaller mounds. A series of burials followed culminating with a huge tomb (tomb f) shortly before 400 B.C.E. Morris views these exceptional burials as a series of burials of families or a family line disregarding the general practice. ${ }^{128}$ Those burying their dead in this fashion sought to link themselves unmistakably with the past. Not only did they tap into the associations of the massive mound G, but gr. C264 was possibly a selfconsciously 'Homeric' cremation. ${ }^{129}$

A few simple grave markers are recorded between $500-425$ B.C.E. ${ }^{130}$ They are flat, rectangular stone stelae generally much broader and shorter than those favoured in the Archaic period. Often, the only adornment on their plain faces is

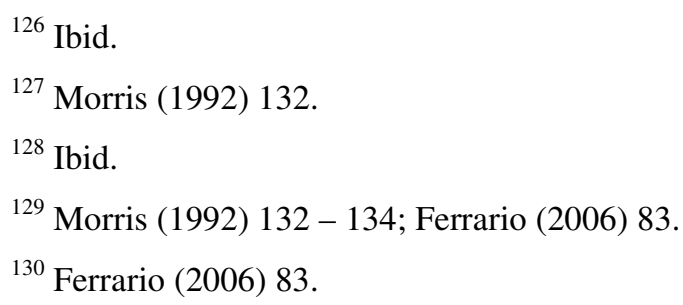


the inscribed name of the deceased, occasionally made more specific with a patronymic or (much more rarely) a demotic. ${ }^{131}$ Some stelae have a few more variations added to them to make them more personalised. Some include decorative moulding, but in the main most conform to a plain slab with an incised name. ${ }^{132}$ Interestingly, nearly all - if not all - of the slightly better decorated funerary monuments of this type, the plain broad stele, dating to the interstitial period between grand monuments were erected for non-Athenians, which has led to some speculation that any existing legislation or 'unwritten custom' may not have held foreigners in such check as it did citizens. ${ }^{133}$

Lekythoi were decorated with monuments bearing no relation to the memorials we know from the archaeological record of the period - they appear to be freestanding columns surmounted by huge acanthus finials (Appendix 2: Fig. 5). ${ }^{134}$ Karouzou and Sarah Humphreys believe the tombs' markers were made of wood, ${ }^{135}$ and David Roselli argues that markers must have been made of 'a more perishable material' than stone. ${ }^{136}$ Clairmont argues that the stelae depicted on lekythoi represented state monuments. ${ }^{137}$ It is possible that the

\footnotetext{
${ }^{131}$ Ibid.

132 Ibid.

133 Ibid, 82; For further discussion of the role of foreigners in Athenian burial customs see Chapter Three.; Roselli (2006) 137; there are about forty-five simple stone reliefs from c. 475 440 B.C.E, most of which commemorate foreigners.

${ }^{134}$ Stears (2000) 33; cf. Roselli (2006) 138 who argues that lekythoi could depict real funeral monuments.

${ }^{135}$ Humphreys (1980) and Karouzou (1956) cited in Stears (2000) 33.

${ }^{136}$ Roselli (2006) 142; Stears argues that there is an apparent absence of post-holes or other foundations to support such monuments which goes against Ridgway's hypothesis. See Clairmont (1983) 36 for a discussion of post-holes.

${ }^{137}$ Clairmont (1970) $74-85$ especially 81.
} 
lekythoi represented myth, or scenes from tragedy, or artistic invention. ${ }^{138}$ Sarah Ferrario, following Morris, argues that lekythoi were involved in a more striking internal dichotomy: that the same burial can be used to express both conforming and nonconforming ideologies, by incorporating a 'conforming' stele and 'nonconforming' pottery. ${ }^{139}$ Grand relief grave markers re-emerged in Athens in the Classical period, around 430 B.C.E., ${ }^{140}$ thus indicating that an ideological shift had occurred in how the dead were viewed: the iconography reflected more domestic aspects of life and women were more often depicted. The elite also appropriated state symbolism to emphasise their status rather than aligning themselves with the Homeric heroes as they had done previously. The re-emergence of grave markers will be addressed in Chapter Three.

\section{Gender}

The majority of Archaic stelae represented men; ${ }^{141}$ Shapiro argues that the main motivation behind most of these representations is the heroisation of the dead. By "heroisation" he does not mean that the dead were turned into objects of cult or chthonic demi-gods, as in some parts of Greece. Instead, they are likened to

\footnotetext{
${ }^{138}$ Oakley (2004) 214.

${ }^{139}$ Morris (1994) 80; Ferrario (2006) 84.
}

140 There is some discussion over the date at which stelae re-appear. This debate will be addressed in Chapter Three, see pp. $93-94$.

${ }^{141}$ Richter has catalogued 79 Archaic funerary reliefs, 45 figure men, 3 figure a man and a woman and none figure just a woman, 31 currently figure neither man nor woman. Richter (1971); Jeffery collected the epigraphical data, 54 archaic Athenian grave inscriptions commemorate men, 1 commemorates a man and woman, 6 commemorate women, and 8 are of unclear gender. Jeffery (1962). The free standing and relief sculptural monuments associated with these inscriptions figure men in 54 cases, women in 8 cases, and in their current state, neither man nor woman in 20 cases. Of figured monuments to the dead, only painted funerary plaques, depicting scenes of mourning and parts of funeral ritual, regularly figure women. Boardman (1955) : Following Osborne (1997b) 12 n.29. I have left out those kouroi of unknown provenance, but it is my aim to show that women are unequally represented across funeral sculpture during the archaic period in Athens. It should also be noted that this iconographic limitation of representing only men was peculiar to archaic Athens, see Ridgway (1977) 164, 174, and 176 and Boardman (1978) fig. 246. 
the heroes whose aretê was celebrated in the Homeric poems. ${ }^{142}$ Shapiro cites the example of Kroisos from Anavysos, a kouros of the 530s B.C.E. (Appendix 2: Fig. 6). Kroisos is presented as youthful, powerful, idealised, and heroically nude. ${ }^{143}$ His death in battle is described in an elegiac couplet carved on the base. The diction is self-consciously Homeric: 'Halt and show pity beside the marker of dead Kroisos, whom raging Ares once destroyed in the front ranks of battle. ${ }^{144}$ The information that Kroisos died in battle is significant, because there is no hint of this in the nude figure, no armour or attribute of war. The marker recalls the Homeric heroes of early red-figure who often fight entirely nude. ${ }^{145}$ The kouros was an idealised rather than realistic depiction.

From the Archaic period there are only two surviving stelae commemorating women: a fragment in Athens with a mother cradling her child, ${ }^{146}$ (Appendix 2: Fig. 7) and the Brother-and-Sister Stele (Appendix 2: Fig. 8), where a little girl has been added alongside her brother, probably because both died young while their parents were alive. ${ }^{147}$ Women did also occasionally receive grave statues. Phrasikleia's (540 B.C.E.) epigram states that she died unmarried (Appendix 2:

\footnotetext{
${ }^{142}$ Shapiro (1991) 632.

143 Ibid.

144 Ibid; On the Homeric diction and vocabulary of Archaic Attic grave epigrams see

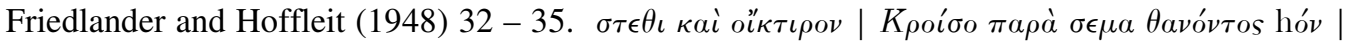

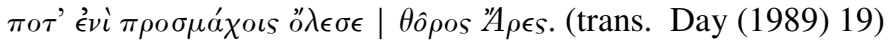

145 Shapiro (1991) 632; A good example is the duel of Achilles and Hektor on an early volutekrater by the Berlin Painter, London E468. : In the case of Kroisos he would have had to have been a hoplite soldier in order to die in battle as described by his epigram. To be a hoplite he would have had to have been over 20, and therefore bearded, details which are missing from the idealized kouros. See Shapiro (2007) 276.

146 The stele was more likely for the child (or for mother and child, if she died in childbirth). Shapiro (1991) 632.n.23.

${ }^{147}$ Ibid, 633.
} 
Fig. 9); this must account in large part for the monument she received. ${ }^{148}$ In addition she is exceptional in that she was evidently commemorated along with a male relative, perhaps her brother. ${ }^{149}$ In the Classical period women were more frequently represented on grave stelae; perhaps the most famous examples are those of the stele of Hegeso (Appendix 2: Fig. 10) and the stele of Pausimache (Appendix 2: Fig. 11). ${ }^{150}$ The role of women on Classical stelae will be examined more closely in Chapter Three, however it suffices to say that this change in iconography reflects a change in Athenian ideology, the nature of which and reasons for which will be examined in detail at a later point.

\section{The Burial}

Grave markers provide a visible indication of the Athenians' view of the dead, but so too do grave goods and the way the deceased was buried. In the Archaic period, inhumation, though less popular than cremation, was often conducted on a magnificent scale, with the dead being laid out on a wooden klinē covered in splinters of ivory and pieces of amber. ${ }^{151}$ Examples of every type of burial practised in the Classical period can be instanced, including pit and periboloi, cist inhumations, burial in terracotta larnakes and stone sarcophagi, and both

148 Svenbro (1993) 19 - 20 for discussion of the unmarried dead, especially in relation to Phraskilea. For a broader discussion see Garland (2001) 25, 72 and $87 \mathrm{ff}$.

149 Shapiro (1991) 633; The sculptor was Aristion; his name is inscribed on the base of

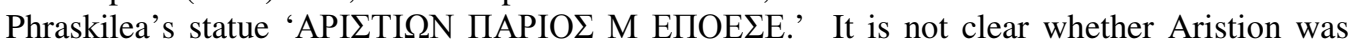
influenced by his Parian heritage or contemporary Attica style. Svenbro (1993) 8 - 25 provides an excellent discussion of Phrasikleia and in particular the inscription. See also Stieber (2004) 11 and Hurtwit (2007b) $265-267$.

${ }^{150}$ Leader (1997) 688.

${ }^{151}$ Garland (1982) 132, an example of this practice is one of the shaft graves in the so-called Südhügel in the Kerameikos which is dated to c. 530 B.C.E. Whitley (2001) 261 dates the Südhügel to between $560-540$ B.C.E. 
primary and secondary cremation. ${ }^{152}$ The most honourable kind of funeral during the Classical period, and consequently the most likely to have been preferred in respect of periboloi, was undoubtedly cremation. ${ }^{153}$ Primary cremation, familiar from the Archaic period, continued into the Classical period, with a noticeable tendency toward simplification; ventilation channels too became much less common. ${ }^{154}$ Between 500 B.C.E. and 425 B.C.E. inhumation in a simple pit was the dominant burial type. ${ }^{155}$ Grave goods accompanied both cremation burials and interment. ${ }^{156}$

Grave goods indicate that there was a change in funeral practice. During the Archaic period in Athens, vast sums were spent on the outward appearance of the grave - the erection of monumental earth mounds, built tombs, and fine funerary sculpture. The actual grave was often unfurnished or very modestly furnished, but was accompanied by the contents of the 'offering places' and 'offering ditches. ${ }^{157}$ These offering deposits have been found close to the grave or apart from it. Their preserved contents are almost exclusively pottery, although some have animal bones and remains of other food offerings. ${ }^{158}$

\footnotetext{
${ }^{152}$ Boardman and Kurtz (1971) 98.

${ }^{153}$ Humphreys (1980); Garland (1982) 131. Particularly noteworthy is a secondary cremation from an enclosure aligning the Street of Tombs in the Kerameikos (AI9), where a bronze cinerary urn and two alabaster boxes were found inside a wooden chest which had been deposited in a small sarcophagos.

${ }^{154}$ Boardman and Kurtz (1971) 98.

${ }^{155}$ Morris (1992) 141.

${ }^{156}$ See Morris (1992) 103 - 127 for a close examination of grave goods and their relation to wealth.

${ }^{157}$ Ibid, 75.

${ }^{158}$ Boardman and Kurtz (1971) 75, 'offering places' (German Opfergrube, Opferplatz) are long shallow furrows which were cut into the ground near the grave, beside or beneath earth mounds, under, beside or a short distance from built tombs. Their length varies from an impressive $12 \mathrm{~m}$. to a more modest 2 to $3 \mathrm{~m}$., their width from 20 to $30 \mathrm{~cm}$ and they were lined with mud bricks. After the offerings had been made, and the flames had died down, the ditch was closed and was
} 
Offering places were optional, and undoubtedly expensive, adjuncts to the standard funerary outlay. The richest examples of these offering places are from the Archaic period. ${ }^{159}$ As with a decline in funereal sculpture there was a decline in grave goods. In Athens grave goods were much less lavish between 500-425 B.C.E than in previous periods. ${ }^{160}$ Grave goods, especially those from periboloi, were generally, but not exclusively, of indifferent quality, the majority being lekythoi, other small jars, iron nails, and the like. ${ }^{161}$

\section{Place of Burial}

Where the dead were buried also changed between the Archaic and Classical periods: extramural burial became the norm and distanced the dead by placing them outside the city walls. Extramural and intramural burial, of adults as well as children, were practised side by side throughout the Dark Ages (1200 B.C.E.800 B.C.E.), but into the eighth century, and with growing urbanisation and the development of the polis, extramural burial began. ${ }^{162}$ This trend grew throughout the Archaic period, with few burials being recorded within the city of Athens. ${ }^{163}$ Certain statements in literary sources can be interpreted as implying the existence of a wall around the lower city before the Persian

apparently never used again. The placement of the ditches seems to indicate that the ceremony during which they were used was the climax of the service of the burial.

${ }^{159}$ Ibid.

${ }^{160}$ Morris (1992) 106; It is possible that some graves are missing grave goods due to being disturbed or robbed. Young (1951) 77.

${ }^{161}$ Garland (1982) 131; In attempting to assess the overall quality of grave deposits, we are severely handicapped, however, by the fact that few peribolos tombs have been excavated completely intact-an indicator, perhaps, that some at least contained objects of value.

${ }^{162}$ Sourvinou-Inwood (1983) 43 - 44.

${ }^{163}$ The exceptions were outlined in Chapter One, see pp. $34-35$. 
invasion. ${ }^{164}$ Both Herodotus $(9.13)$ and Thucydides $(1.89 .3 ; 6.57)$ allude to a pre-Themistoclean wall, but to date no trace has been found.

The only literary evidence of the Athenian practice of burying the dead outside the city's wall comes from a letter by Cicero (ad Fam. 4.12.3): 'I could not induce the townspeople to grant him burial within the city precincts; they pleaded a religious bar. ${ }^{, 165}$ On the basis of these words, it is assumed, by Rodney Young, that in Athens there was a ban on burials within the city walls, which was probably introduced about 500 B.C.E. ${ }^{166}$ Kamen states that extramural burial started much earlier, c. 750 B.C.E., due to shifting notions of miasma. ${ }^{167}$ Richard Seaford argues that intramural burial declines from the $8^{\text {th }}$ century B.C.E. onwards across Greece but is not exactly certain of when it happened in Athens. ${ }^{168}$ Morris argues that around 700 B.C.E, Athenian cemeteries were moved outside the living space; and that even before this some burials were being enclosed in walls. ${ }^{169}$ Boardman and Kurtz doubt whether there was an absolute ban from 500 B.C.E. They cite the few intramural burials of the Classical period - mostly of children, however children are a known exception to funerary legislation. ${ }^{170}$ The few intramural graves of adults are less

\footnotetext{
${ }^{164}$ Young (1951) 131.

165 ab Atheniensibus locum sepulturae intra urbem ut darent impetrare non potui quod religione se impediri dicerent. (trans. Bailey)

166 Young (1951) 131; Patterson (2006b) 12 refutes the notion that Cicero's letter provides evidence of extramural burial, stating it is hardly conclusive evidence of classical Athenian "extramural" burial, given both its date and the fact that a murder victim might be a special case.'

${ }^{167}$ Kamen (2007) 103; Wycherley (1978) 253.

${ }^{168}$ Seaford (1994) 117.

${ }^{169}$ Morris (1989) 317.

${ }^{170}$ Boardman and Kurtz (1971) 70; Young (1951) 133.
} 
easily dismissed. ${ }^{171}$ It appears that the Kerameikos throughout the Classical period continued to be an important burial ground, but not until the Hellenistic period are burials in any number evident. ${ }^{172}$ After the construction of the Themistoclean wall (479 B.C.E.), existing cemeteries were extended outside of the gates and new cemeteries grew up outside the gates. ${ }^{173}$ The close proximity of the cemeteries to the walls is easy to understand when we bear in mind that burial grounds had to be reasonably accessible so family members could easily commemorate their dead, ${ }^{174}$ yet far enough away to limit the effects of miasma.

Archaeology and epigraphy record that throughout the Archaic period graves were placed along roadsides, and that the roadside was the preferred place of burial, especially those roads running through the Kerameikos. ${ }^{175}$ Archaeological evidence indicates that during this period burials within a cemetery or within a plot were common, however no published grave epigrams make reference to the siting of a monument within a plot or cemetery. ${ }^{176}$ Often the grave markers had poems inscribed upon them that celebrated and commemorated the dead, but sometimes epigrams could serve a different

\footnotetext{
${ }^{171}$ Boardman and Kurtz (1971) 70.

${ }^{172}$ Ibid, 93. In the fifth century intramural burial is almost unknown outside Sparta and Taras. Burials within the city were reserved for the city leaders.

${ }^{173}$ Boardman and Kurtz (1971) 92.

${ }^{174}$ Ibid; Patterson (2006b) 14.

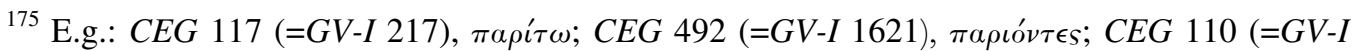

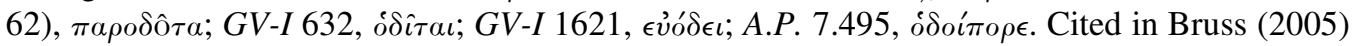
39.

${ }^{176}$ Morris (1987) 29 - 69. A cemetery and plot differ from one another in that a plot may be, but need not be, contained with a larger cemetery. Bruss (2005) 38 .
} 
purpose, such as the sixth century epigram below, which draws attention to the grave's position by the roadside. ${ }^{177}$

Archeneos set up this marker...

Near the road, of a noble and prudent man. ${ }^{178}$

This epigram contains standard encomiastic language and as with many other epigrams is linked specifically to archaic society's use of epigram to advance aristocratic social values. ${ }^{179}$ The deceased relative or friend of Archeneos was said to be $a \gamma \alpha \theta$ ós and $\sigma o ́ \varphi \rho \omega \nu$, both quintessential aristocratic value-terms, but crucially Archeneos set up the monument near the road, one of the most desirable places to be buried as it was the most publicly visible to those walking past. Archaic grave epigrams often celebrated the individual, especially those who died in battle, and sought to increase the kleos of the deceased. ${ }^{180}$ Into the Classical period kleos became associated more with the monument itself, but some monuments still made reference to the grave's placement, for example:

For the famous Philemon his grandsons erected me here, A crown desirable for those who pass by on the road. ${ }^{181}$

177 Bruss (2005) 38; Humphreys (1993) 91 - 92, 'Several epitaphs mention explicitly that the grave is by the roadside, as graves normally were and the more frequented the road, the better the site.'

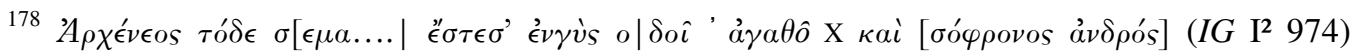
(trans. Bruss (2005) 40)

${ }^{179}$ Bruss (2005) 40.

${ }^{180}$ Ibid.

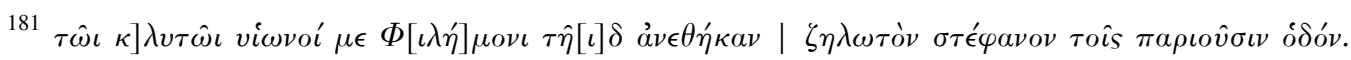
(IG II/III ${ }^{2}$ 888, 11 614a) (trans Bruss (2005) 46.) This elegiac couplet accompanies a grave relief from Athens. 
This epigram, from Athens, which dates to the fourth century B.C.E., shows the family relation and thus the archaic development of the monument from a "marker" to a conveyer of memory is evident. ${ }^{182}$ People would have read these inscriptions aloud as they walked past and consequently performed a literal enactment of kleos (etymologically related to kluo, I hear). ${ }^{183}$ Into the Classical period epigrams continue to evolve; perhaps the biggest difference is that they now mention longevity. ${ }^{184}$ The relief of Ampharete and her grandson (Appendix 2: Fig 12) commemorates her as a grandmother and the marker for Lysimache reports that she was a priestess of Athena Polias for 64 years in the late fifthearly fourth centuries B.C.E. She died when over 80 (or 90 years old) having lived to see four generations of descendents. ${ }^{185}$

\section{Literature}

Literature too points to a change in funeral practices and beliefs. The first recorded account of a funeral in Greek literary tradition comes from Homer's Iliad. The Iliad is a poem of death: 318 heroes, 243 of them named, get killed. ${ }^{186}$ The Iliad provides an account of the funerals of Hector (Il. 24) and Patroclus (Il. 23), both heroic funerals, which would have been atypical, ${ }^{187}$ but nonetheless provides a probable framework for how aristocrats during the early Archaic period interacted with and buried their dead. ${ }^{188}$ Whether archaic

\footnotetext{
182 Bruss (2005) 45.

${ }^{183}$ Svenbro (1993) 18.

${ }^{184}$ Humphreys (1993) 107.

${ }^{185} I G \mathrm{II}^{2} 10650$ and $I G \mathrm{II}^{2} 3453$ respectively. See Humphreys (1993) 107 for further examples.

${ }^{186}$ Morris (1989) 303; Bassett (1938) 256 n.37.

${ }^{187}$ Morris (1989) 303; For a fuller discussion of the funeral rites for Patroclus see Albinus (2000) $27-42$.

${ }^{188}$ The 'Homeric question' falls outside the scope of this thesis. But I accept that the Homeric
} 
aristocrats performed funerals in line with the heroic ideal as presented in epic or whether epic reflects early archaic practices we do not know. Vases provide depictions of grand funerals and funeral games which parallel epic accounts, but the vases could easily be a depiction of the epic tradition rather than actual practices. $^{189}$

Both heroic funerals in the Iliad are protracted events. Patroclus was cremated on a funeral pyre, and his bones were collected into a golden urn in a double layer of fat (Il. 23.253 - 254). The tumulus was built on the location of the pyre (Il. 23. 255 - 257). ${ }^{190}$ Achilles then initiated funeral games, consisting of a chariot race, boxing, wrestling, running, a contest between two champions to the first blood, discus throwing, archery and spear throwing (Il. $23.257 \mathrm{ff}$.). The funeral games would have been quite a spectacle, and seem to parallel what happened in reality. ${ }^{191}$ Many vases have been found which depict funeral games, ${ }^{192}$ but which also would have been used as prizes at funeral games. These games would have been the ideal opportunity for a wealthy Athenian clan to win favour from the populace by offering expensive prizes to the victors, and also would have caused much disruption to the polis.

poems were probably written down in the $8^{\text {th }}$ century B.C.E, and stem from an earlier oral tradition.

${ }^{189}$ Roller (1981) 107 - 119; Seaford (1994) 120 - 121.

${ }^{190}$ Petropoulou (1988) $482-495$.

${ }^{191}$ Loraux (1986)

${ }^{192}$ The most famous of these is the 'Francois Vase' which depicts the funeral games of Pelias. See Roller (1981) 107 - 119 for further discussion. 


\section{Afterlife Beliefs}

A diversity of opinions about the afterlife in the Archaic Greek world is evidenced. Homeric man is almost entirely free of any fear of the dead. ${ }^{193}$ In Homer's Nekyia (Od. 11) the majority of the dead are neither punished nor rewarded, but instead face a relatively nondescript existence in the underworld. ${ }^{194}$ This Homeric view can be contrasted with that of Pindar, who was perhaps influenced by Pythagorean or Orphic beliefs. ${ }^{195}$ In his Second Olympian of 476 B.C.E. he indicates that the souls of good men were rewarded in Hades (57-67). ${ }^{196}$ However in another episode of Homeric epic, Proteus talks about a never troubled life in the Elysian fields (Od. 4.561-9), similar to Pindar's underworld in Olympian 2.

The initiates who took part in certain mystery cults thought a similarly positive fate awaited them:

Happy is he among men who has seen [the Eleusinian Mysteries]; but he who is uninitiated and who has no part in them never had a similar lot of good things once he is dead, down in the darkness and gloom. (Homeric Hymn to Demeter 480-2). ${ }^{197}$

Isocrates claims that 'those who have participated [in the Eleusinian Mysteries] have sweeter hopes regarding both the end of life and the whole lifetime'

\footnotetext{
${ }^{193}$ Garland (1982b) 70; Rhodes (1925) 9.

${ }^{194}$ Kamen (2007) 104.

${ }^{195}$ Ibid.

${ }^{196}$ Ibid, 105.

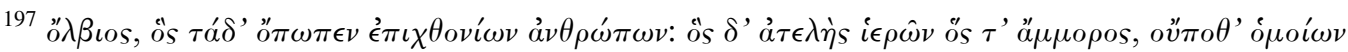

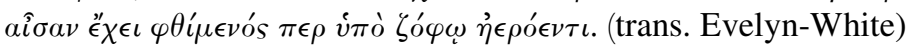


(Panegyricus 28.10-12). The formulation of Sophocles is stronger: 'Thrice blessed are those mortals who descend to Hades after seeing these rites; for them alone there is life there, for the rest all is evil' (frag. 719 Dindorf). ${ }^{198}$ The scholialist on Aristophanes' Frogs (158) states clearly what these other rather allusive sources hint at: 'It was the common belief in Athens that whoever had been taught the Mysteries would, when he died, be deemed worthy of divine glory. Hence all were eager for initiation. ${ }^{, 199}$

Orphism represented an alternative outlook. Guilt and punishment, merit and reward become central to Orphic teaching, which recognized the importance of moral purity as a means of attaining blessedness. Hades, under such influence, came to be regarded as a place of punishment for evildoers. The Orphics, who were already influential in some circles as early as the sixth-century B.C.E., had affinities with the Pythagoreans and like them taught a doctrine of transmigration of souls. ${ }^{200}$

Morris argues that there is no evidence for a massive shift in ideas of the afterlife which would have 'caused' the changes in burial, except in the weak sense that since tombs are part of the rituals which incorporate the soul into the next world, then restraint in them means a priori that lavishness was considered inappropriate for the dead. ${ }^{201}$ However, literary material supports the theory that there was a changing mentality towards death around the same time as the

\footnotetext{
${ }^{198}$ Cited in Angus (1928) 238.

${ }^{199}$ Ibid, 238 - 239.

${ }^{200}$ MacGregor (1992) 73.

${ }^{201}$ Morris (1992) 147.
} 
decline in funeral monuments: the afterlife was becoming a more fearful place and therefore death a more fearful prospect. This development in afterlife belief - the growing fear of the afterlife - may be tied into a growing fear of death and of miasma. Grave monuments in the Classical period appear to have a more familial focus - often one figure is seen greeting another with a handshake, the dexiosis. ${ }^{202}$ The dexiosis accompanied by the growing trend of placing burials together in periboloi (a grave precinct surrounded by walls) indicates that perhaps there was a growing belief that the family would be reunited in the afterlife, and therefore it was even more necessary to bury family members with proper rites in order to meet them again in the hereafter.

\section{Laws}

Surviving in literature are references to Athenian laws, and it is these laws which have often been cited as the reason for the change in funeral practices in Athens between 480 and 430 B.C.E. ${ }^{203}$ However this may not be the total story what the laws contained in Plutarch, Cicero and [Demosthenes] do show us is that in the Archaic period there was a shift in attitudes regarding death, but they were not necessarily the catalyst for that change. ${ }^{204}$

\footnotetext{
202 Johansen (1951) 151.

${ }^{203}$ Leader (1997) 101, 'These [stelae] had disappeared by the beginning of the fifth century B.C.E., which is usually interpreted as the result of sumptuary legislation.'

${ }^{204}$ Osborne (1997b) 3 - 33 provides a good discussion on whether new laws bring about social change or reflect change; he then applies his analysis to Pericles' citizenship law. Also with these recorded laws it is crucial to take into account the conditions in which the recorder of the law was writing. For example, Plutarch's Life of Solon is not a comprehensive historical account of the lawgivers' actions but a presentation of Solon according to Plutarch's moral values. For a good discussion of this complicated topic see Lewis (2007) especially pages 1125 .
} 
The law as recorded in [Demosthenes]'s Against Makartatos (Appendix 1: 1) states that the prothesis should be one day long, that the ekphora was to take place before sunrise, that the men were to walk at the front and women at the rear, and that it was forbidden for women to enter the house of the deceased and to follow a corpse when it is taken to the grave when she is under sixty years, except those women who are within the degree of second cousin. Cicero, too, in his discussion of the Twelve Tables (De Leg 2. 59-2.66, Appendix 1: 4a, b, c), relates that Solon's regulations limited the expense to three veils, a purple tunic, and then pipe players and also limited mourning: 'women shall not tear their cheeks, nor have a lessus at a funeral. $^{, 205}$ (Appendix 1: 4a. 2.59). Finally, Plutarch in his Life of Solon (Appendix 1: 5) records that Solon made regulations regarding funerals, but perhaps more specifically about women and how they could behave at a funeral in order to put an end to disorder (21.5-7). Women were not to go out with more than three pieces of clothing, nor carry food or drink worth more than the value of an obol, nor a basket larger than a cubit, nor should they travel at night except in a wagon carrying a lit lamp. Self-inflicted wounding by mourners was banned, so too was the singing of dirges and the bewailing of someone at another's funeral. Solon forbade the sacrifice of an ox, and limited the number of garments the deceased could wear.

The legislation outlined above has been thoroughly studied. Those who study it generally fall into one of two camps. On the one hand are scholars who see the

${ }^{205}$ Mulieres genas ne radunto neve lessum funeris ergo habento. Cicero then goes on to explain what a lessus is: 'The older interpreters, Sextus Aelius and Lucius Acilius, admitted that they did not fully understand this, but suspected that it referred to some kind of a mourning garment. Lucius Aelius thought a lessus was a sort of sorrowful wailing, for that is what the word would seem to signify. I incline to the latter interpretation, since this is the very thing forbidden in Solon's laws.' See Appendix 1: 4a for the Latin. 
purpose of such legislation as sumptuary measures implemented by those managing the polis at a given time, who were exercising their legal and political sovereignty over the polis. ${ }^{206}$ Such attempts aimed to restrict spending, the number of participants, the types of encomia, and such, and can be viewed as hemming in the potential for disruption to the life of the polis and aristocratic extravagance. On the other hand is a more culturally and ritually oriented analysis, most fully argued by Sourvinou-Inwood, ${ }^{207}$ which views such legislation as having only secondary and largely unintentional 'political' or 'economic' (anti-sumptuary) consequences. It is this interpretation which best fits the Athenian laws attributed to Solon, as his funerary legislation sought to restrict the possibility of contamination, the disruptive effects of miasma, and to provide measures for catharsis of those necessarily polluted through having partaken in the rituals of death and the attendant expressions of grief in the funeral. This was done by regulating who must or must not be returned to the home after the burial of the corpse, what elements of the funerary apparatus must not be allowed to touch "public" spaces, specific measures for the isolation and or cleansing of the deceased's home and relations. These measures sought to regulate and normalise the community and the means by which the mourners were re-aggregated to the polis after a period of liminal existence.

Ultimately both sides are talking about the same result, namely the attempt through expressions of legal authority to limit disruption to the community and

\footnotetext{
206 This view has found effective proponents in, inter alia, Gagarin (1986) and Hölkeskamp (1999), (1992a) 87 - 117, and (1992b) 49-81. With specific regard to funerary law, Garland (1985) and (1989) 1 - 15, Morris (1987) and (1989) 296 - 320, and Seaford (1994) 74 - 105. Toher, (1991) $159-175$.

${ }^{207}$ Sourvinou-Inwood (1995); Sourvinou-Inwood (1981) 33 - 48; Parker (1983).
} 
the best way to achieve a stable and sustainable balance in the Greek polis, which in its archaic phases Lin Foxhall has aptly described as 'little more than a standoff between the members of the elite who ran them. ${ }^{208}$ Separating out the ritual and the political does seem artificial and anachronistic as in the Archaic period it is highly unlikely that the two 'circles' were so separate, in fact they were embedded in society. It is also important to note that the legislation introduced by Solon was not strictly sumptuary as it is often claimed. As pointed out by Shapiro, there is no limit on expense. ${ }^{209}$ Closer examination of the laws will be carried out in Chapter Two.

\section{The Development of State Funeral}

Not all Athenians died in battle, but the state funeral was a crucial part of the democratic ideology. ${ }^{210}$ In 490 B.C.E., 192 Athenians who fell at Marathon to save their city from the Persian threat were buried in a communal grave, the socalled soros, at the site where they died (Thuc. 2.34) (Appendix 2: Fig 13). This was not the first time Athenian casualties were buried in a communal grave: in 506 B.C.E. those who died near the Euripos River on Euboea, in a victory over the Boiotians and Chalcidians, were buried there in a polyandrion at the expense

\footnotetext{
${ }^{208}$ Foxhall (1997) 119; Bryn Mawr Review, by J. G. Hawke on L. Frisone, Leggi e Regolamenti Funerari nel Mondo Greco: I. Le Fonti Epigraphiche. Lecce: Università di Lecce, Scoula di Specializzazione in Archeologia Classica e Medioevale, 2000.; The consequences of preferring one explanatory model or another for the motivations of such attempts at regulation do have consequences for the larger, so-called "primitivist-modernist" debate about the archaic polis, but they fall outside the scope of this study.

${ }^{209}$ Shapiro (1991) 630; Sumptuary law is a term taken from the Latin sumptuariae leges and refers to laws relating to expense. By this strict definition the laws of Solon are not sumptuary as such; it is arguable that stopping ox sacrifice could have been a price related issue, but it seems more likely that it was an attempt to limit the spectacle that would have been an ox being sacrificed by the graveside.
}

${ }^{210}$ Morris (1992) 129. 
of the Athenian state. ${ }^{211}$ And at some time in the 490s B.C.E., a contingent of Athenians with Miltiades who died fighting the Pelasgians on the island of Lemnos was buried there, with a stele listing those who had fallen according to membership in the recently established Cleisthenic tribes. ${ }^{212}$ Those who died at Marathon were the first to get a polyandrion on Attic soil, a polyandrion with many similarities to the way in which the heroes in the Iliad were buried. ${ }^{213}$ The Marathon dead were cremated and placed beneath a tumulus with offerings of black-figure lekythoi placed in a clay-lined trench alongside. ${ }^{214}$ This burial appropriated an aristocratic set of ideals, presented in the private aristocratic burial markers, and likened the death of these soldiers to the Homeric heroes, using them to honour the war dead of the new democracy. In the burial of those who died at Marathon it is clear that the new democracy took over aristocratic symbols and values for its own ends. ${ }^{215}$

For some reason, perhaps because burial tumuli were still associated with aristocratic burials and were not fully appropriated as a democratic tool, fallen Athenian soldiers stopped being buried where they fell and their remains were brought back to Athens. ${ }^{216}$ The area immediately outside the city gate was a state burial ground. The Athenians, unlike other Greeks, ${ }^{217}$ did not regularly

211 This is known from the epigrams preserved in the Greek Anthology and attributed to Simonides.; Page (1975) 9 line 86 cited in Shapiro (1991) 64. n.92. Polyandrion refers to a burial of multiple men in a communal grave.

212 Shapiro (1991) 644; Clairmont (1983) 88.

${ }^{213}$ See Fig. 14 for a drawing of what the soros may have looked like. The size and tumulus shape is similar to those described for Patroclus in the Iliad.

${ }^{214}$ Whitley (2001) 364; The mound is also noted by Pausanias at 1.32.3.

215 Ibid.

216 Ibid.

${ }^{217}$ Ibid. 
bury their dead where they fell, but in state graves in Athens, which they set up in the Demosion Sema, 'which is situated in the most beautiful suburb of the city; there they always bury those fallen in war, except indeed those who fell at Marathon.' (Thuc. 2.34.5). ${ }^{218}$

The Athenian state honoured its war dead in two types of ceremonies. One took place on the day of the funeral and corresponds to ta trita of private burials. ${ }^{219}$ The other was an annual celebration. Both were apparently performed at the grave. The prothesis was followed by the ekphora with the women performing the lament. The state funeral differed from private funerals in being financed by the state and in the delivery of the funerary oration. One speech, called the epitaphios logos, was given to collectively celebrate all of the war dead. The best-known example of the epitaphios logos occurs in Thucydides' account of Pericles' Funeral Oration (2.34). Pericles delivered it for the men who fell in 439 B.C.E. against the Samians (Plutarch, Pericles 28.4). ${ }^{220}$ According to later ancient sources the custom began soon after the Persian Wars (Dion. Hali. Ant.Rom. 5.17.4 : Dio. Sic. 11.33). The state funeral limited the participation of the family, and shifted the focus from a private and individual focus to a collective celebration of those who died on behalf of the polis.

The state set up the so-called 'casualty lists' in honour of the year's war dead. This meant that soldiers who died in battle did not have a private monument set

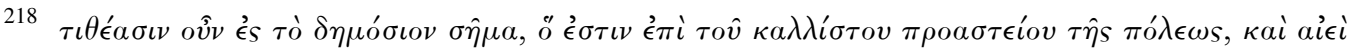

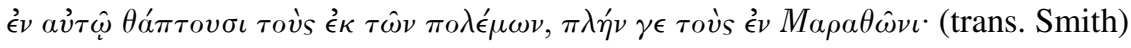

${ }^{219}$ Boardman and Kurtz (1971) 112.

${ }^{220}$ Ibid.
} 
up by their family which could publicly yet individually celebrate their death and the glory of their family, but rather were now one of many who died on behalf of the polis. There are more than thirty of these 'Casualty lists' known, of which the earliest dates to 464 B.C.E. ${ }^{221}$ Only in the years that there was a war would stelae be set up to the dead and an epitaphios logos delivered, originally ten separate stelae, later one monument. ${ }^{222}$ State burial restricted the role of the oikos in the funeral and thereby drew focus to the polis creating a shift from the individual to the collective (see Chapter Two). The funeral was appropriated and used as a tool to aid the creation of democracy. ${ }^{223}$ With the rise of the polis in the Archaic period, a good death was defined in terms of civic service: it was now 'a fine thing for a brave man to die when he has fallen amongst the front ranks while fighting for his homeland.' (Tyrtaeus fr.10.1$2)^{224}$

\section{Conclusion}

The Archaic funeral had been a grand affair as demonstrated by surviving literature and archaeology. However, between 510 and 480 B.C.E it is evident that a change in burial practices occurred in Athens. The archaeological record shows a clear change: the lavish grave markers - kouroi, korai, and stelae begin to dwindle in numbers and quality between 510 and 480 B.C.E and then disappear for 50 years, bar a few exceptions, an occurrence that was specific to Athens. When they re-emerge, c. 430 B.C.E, the grave marker is no longer the

${ }^{221}$ Ibid.

${ }^{222}$ Ibid.

${ }^{223}$ Bennett and Tyrrell (1999) 444.

224 (trans .Kamen (2007) 101). This idea carried on into the Classical period, see Herodotus (1.30-1) and Thucydides (2.42-6). 
domain of the idealised youth reminiscent of the Homeric hero; women and the domestic sphere become more regularly depicted, and where men were individually celebrated they now used state symbols to define themselves. Many poleis had laws governing funerals and funeral behaviour, which has led some to view the Athenian developments as part of a Panhellenic trend, however Athens is unique and as such we should be looking inside Athens to explain the disappearance and then re-emergence of Athenian grave markers. That Athenians thought laws were necessary shows a growing concern surrounding death, and possible effects of miasma. That miasma was a growing concern is indicated by the increased push towards extramural burial. Burials were grouped outside the city's wall; perhaps a reflection of the developing mindset regarding the afterlife - there was a growing belief in being reunited with one's family in the afterlife. Perhaps the greatest change in funeral behaviour was the creation of the state burials in the Demosion Sema. Funerals went from being private aristocratic affairs used by wealthy families to win the favour of the demos, to more regulated occasions organised by the state. 


\section{Why the Change in Funeral Practices Took Place}

This chapter examines the reasons behind the change in Athenian funeral practice and ideology at the turn of the Classical period: from the extravagant private funerals and grave markers of the Archaic period to the state burials and limited private celebrations of the early Classical period. Such a change of practices will naturally be the result of many factors: an increase in population, a lack of space, redistribution or lack of wealth, legal and political changes, a change in fashion, or a move from the individual to the collective. Richter cites the Persian Wars as the catalyst for a change in funeral practices. ${ }^{225}$ Morris argues that the change was part of a Panhellenic trend; ${ }^{226}$ Cannon argues that the anti-display of the early fifth century is part of a larger historical pattern of expenditure and restraint; ${ }^{227}$ Anthony Snodgrass has emphasised the importance of religious development and the growth of communal sanctuaries. ${ }^{228}$ Stears discusses the increase in votive offerings at the same time as the decline in sepulchral monuments; ${ }^{229}$ Judeich, Garland and Sourvinou-Inwood link the change to a growing fear of miasma; ${ }^{230}$ Meyer, Robin Osborne and James Whitley link the change to the growth of democracy and establishment of state burials. ${ }^{231}$ The arguments of these scholars will be more closely examined in the course of this chapter. I hypothesise that there was a shift of focus from the

\footnotetext{
${ }^{225}$ Richter (1961) 53.

${ }^{226}$ Morris (1992) 146.

${ }^{227}$ Cannon (1989) 444.

${ }^{228}$ Snodgrass (1980) $52-65$.

${ }^{229}$ Stears (2000) 46.

${ }^{230}$ Judeich (1931) 131 cited in Young (1951) 132 n.30; Garland (1998) 119; Sourvinou-Inwood (1983) $38-42$.

${ }^{231}$ Meyer (1993) 108; Osborne (1997b) 27; Whitley (2001) 366.
} 
individual to the collective: that death was appropriated by the polis, resulting in glorified state burials, which, together with the epitaphios logos, aided the development of democracy in Athens. In Homer's epics, the monumental tomb helped to create deathless glory for the individual hero; in fifth century Athens this association was turned on its head, with oikoi refraining from elaborate markers, while the polis used the tomb to promote a communal ideal, rather than glory for a specific individual.

\section{Population and Space}

Population changes affect how the dead are dealt with; this is especially true of population growth as it puts more pressure on resources. ${ }^{232}$ However, whether the Athenian population between 530 and 400 B.C.E. was increasing, declining or stationary is much debated. The best evidence for Athenian citizen numbers in the fifth century B.C.E. comes from Thucydides' account of Athenian human resources at the outbreak of the war with Sparta in 432 B.C.E. (2.13). ${ }^{233}$ Arnold Gomme calculated a citizen population of 43,000 on the basis of the figures provided by Thucydides. ${ }^{234}$ It has more recently suggested that the figures would be compatible with a citizen population as high as 60,000 in the mid-fifth century B.C.E. to a minimum of 25,000 by the end of that century, with a 'recovery' to 30,000 or so by 330 B.C.E. ${ }^{235}$ Mogens Hansen also shows that in the fourth century B.C.E. 'the number of Athenians living in Attica must have

\footnotetext{
${ }^{232}$ Morris (1989) 301; This is shown, albeit in extreme form, by Thucydides' report that during the plague as people died in large numbers traditional burial practices were ignored Thuc. (2.47$55)$.

${ }^{233}$ Similar figures are offerd by Diodorus Siculus $(12.40-44)$ but it is not clear who his source is. Herodotus $(7.184 ; 8.17)$ implies that a warship had a crew of 200 and that there were 35,000 citzens at the time of the battle of Salamis in 480 B.C.E. Morris (1987) 99.

${ }^{234}$ Gomme (1933) $25-39$.

${ }^{235}$ Hansen (1986) 65 - 69; Scallares (2001) 95.
} 
been almost stationary and sometimes even declining' due to slow natural growth combined with the emigration of citizens. ${ }^{236}$ Morris puts the population of Athens at around 35,000 - 40,000 in 431 B.C.E, and 'rather less earlier in the fifth century. ${ }^{237}$ Osborne states that it is not in itself improbable that the Athenian citizen population grew abnormally fast between 500-430 B.C.E. at a growth-rate of about one per cent per annum. ${ }^{238}$ Cynthia Patterson accepts there was an increase in population and has suggested that most of this increase in the citizen population was due to the enrolment of foreigners in the demes and phratries in the years after the battle of Salamis. ${ }^{239}$ If we accept that the population in Athens was relatively static, perhaps with minor increases, then the change in burial practices may not bear a direct correlation to space, although the number of burials uncovered in this period increases from three percent per annum in 500 B.C.E. to around nine per cent per annum in 450 B.C.E ${ }^{240}$ which would have put more pressure on burial space, and also indicates a change in ideology as more Athenians were receiving burial.

Space in Athens itself was limited due to the city's wall, and as noted in the first chapter sepultura intra urbem was banned c. 500 B.C.E. for the majority of Athenians. ${ }^{241}$ Space within the Kerameikos probably became limited due to the fashion of building large funeral mounds, akin to that described for Patroclus in

\footnotetext{
${ }^{236}$ Hansen (1986) $65-69$.

${ }^{237}$ Morris (1987) 101.

${ }^{238}$ Osborne (1997b) 5; Scallares (2001) 86, 95 also argues that the population increased substantially between $480-430$ B.C.E.

${ }^{239}$ Patterson (1981) 102.

${ }^{240}$ Whitley (2001) 366; 186 fig 8.10 provides a graph which outlines the growth in grave numbers between 950 B.C.E. and 700 B.C.E., a pattern which Whitley argues is repeated c. 430 B.C.E.

${ }^{241}$ See Young (1951).
} 
the Iliad (Il. 23. 255-257). ${ }^{242}$ From c. 580 B.C.E onwards large earth-mounds of the kind which had been popular in the Kerameikos during the seventh century again became popular, having been substituted by built-tombs of mudbrick (c. 610-600 B.C.E.) due to a shortage of space. The new series of burial mounds culminated in two mounds of vast proportions, Mound G and Südhügel, which were erected in the middle of the sixth century B.C.E. ${ }^{243}$

\section{Miasma}

The ban on intramural burials was probably instituted for two main reasons: a lack of space for burials in the Kerameikos, as I have discussed above, or because of a growing fear of the miasma associated with the dead. Judeich's argument connects the initiation of the ban on burial within the city with the purification of Athens by Epimenides. ${ }^{244}$ The date of Epimenides has been disputed. Plato tells us that Epimenides visited Athens ten years before the beginning of the Persian Wars (499 B.C.E.) to carry out sacrifices ordered by the Delphic god (Laws 1642 D). Plutarch makes Epimenides a contemporary of the Athenian Lawgiver Solon (594 B.C.E), which would date him nearly a century earlier (Solon 12.4-6). ${ }^{245}$ If we accept Plutarch's dating for Epimenides, it would place him at the end of the sixth century. However, the date of ten years before the Persian war accords well with the evidence from the Kerameikos; but we are nowhere told specifically that the ban on burial within

\footnotetext{
${ }^{242}$ Petropoulou (1988) $482-495$.

${ }^{243}$ Whitley (2001) 261.

${ }^{244}$ Judeich (1931) 63. n. 6; 122 cited in Young (1951) 131; See Young (1951) 132 n.30 for further discussion on the date of Epimenides.

${ }^{245}$ See Young (1951) 132 n.30.
} 
the walls was connected with the purification, though because of an increasing fear of death, it is likely that it was.

Garland, too, argues that burials were banned from the city because of the fear of the miasmic effect of the dead, rather than a lack of space. ${ }^{246}$ The fear of miasma associated with death indicates a change in Athenian ideology concerning death, as Sourvinou-Inwood argues: attitudes to death in the Greek Dark Age and eighth century B.C.E. represent the 'familiar' or 'accepting' type, a version of the 'Tamed Death' described by Philippe Ariès in his analysis of changing attitudes to death in medieval and modern Europe. ${ }^{247}$ But the development of the polis brought about a new attitude of anxiety about death and fear of its miasma, and the funerary legislation is to be explained, Sourvinou-Inwood claims, as belonging to this general shift, a growing fear of death which results in death being pushed outside the city's wall. ${ }^{248}$

As a part of the ban on intramural burials graves were erected along the roadside and outside the city's wall. Apart from a few who still retained the right to be buried within the city's wall, families sought to place their dead as close and as prominently to the city as possible. Burials along the roadside, near the city gates and near the city walls are easily understandable on two counts: firstly, burial along a roadside would provide maximum exposure of the gravestone to the passing public, and secondly, cemeteries had to be close to the

\footnotetext{
${ }^{246}$ Garland (1998) 119.

${ }^{247}$ Ariès (1981) 18 - 21; Sourvinou- Inwood (1983) 38 - 42.

248 Sourvinou- Inwood (1983) 38 - 42; Morris (1989) attacks Sourvinou-Inwood's general stance, without mentioning funerary legislation. For a summary of both sides of the argument see Seaford (1994) $79-80$.
} 
city, as visiting them was an essential part of Athenian life. The placement of burials was important, as is demonstrated by the number of markers which make reference to their placement (see pp $44-45$ ), and allowed for status to be distinguishable in death - presumably the more prominent a burial plot the more expensive it was. ${ }^{249}$ If monuments were curtailed by the law or by the aristocrats who felt pressured to conform to a new democratic ideology, placement of the burial would still have been a way for the aristocrats to distinguish themselves. State burials would have held some of the most prominent burial ground in Athens, being set up in the Kerameikos, so burial by roads and gates could have been a way for aristocrats to distinguish themselves.

\section{Demographics and Economics}

Economics may have played a part in the simplification in burial of the dead. It may have been that towards the end of the fifth century B.C.E. an attitude developed whereby it was considered prudent to be less conspicuous with money and as a result funerary sculpture was no longer viewed as an appropriate way to spend wealth, an idea expressed by Cannon and termed 'expressive redundancy.' Cannon's theory of display of wealth notes that when the grand displays begin to diminish the trend starts amongst the wealthiest. ${ }^{250}$ Morris reads Thucydides' (1.6.3) words as an indication that display was working from the bottom up, unlike the Cannonian model: ${ }^{.51}$

\footnotetext{
${ }^{249}$ It is not clear who owned the land. See Closterman (2006b) 15 - 19 for a further and fuller discussion.

${ }^{250}$ Cannon (1989) 444.

${ }^{251}$ Morris (1992) 152.
} 
But the Athenians were among the very first to lay aside their arms and, adopting an easier mode of life, to change to more luxurious ways. And indeed, owing to this fastidiousness, it was only recently that their older men of the wealthier class gave up wearing tunic of linen and fastening up their hair in a knot held by a golden grasshopper as a brooch; and this same dress obtained for a long time among the elderly men of the Ionians also, owing to their kinship with the Athenians. ${ }^{252}$

Aristophanes (Knights 1321-34; Clouds 94-6) associated the kind of display outlined in Thucydides (1.6.3) with the generation of Marathon. ${ }^{253}$ Thucydides' account of Greek dress goes on:

An unpretentious costume after the present fashion was first adopted by the Lacedaemonians, and in general their wealthier men took up a style of living that brought them as far as possible into equality with the masses. (Thuc. 1.6.4) ) $^{254}$

Morris then goes further and suggests that this Thucydidian passage did not just refer to Athens, but that 'the modern taste' was a general Greek fashion, part of a Panhellenic trend of restraint. ${ }^{255}$ Cannon picks up on the reference to clothing and asserts that 'mortuary patterns are in a class with fashions in dress, luxuries,

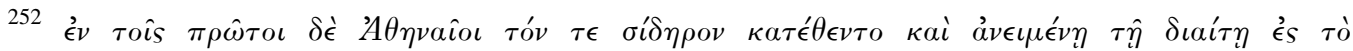

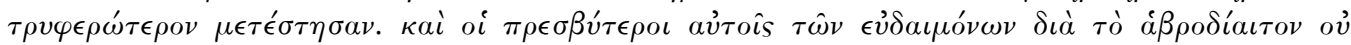

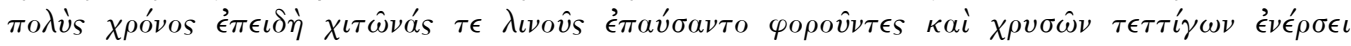

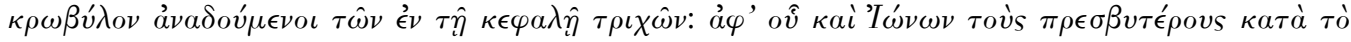
$\xi v \gamma \gamma \epsilon \nu \dot{\epsilon} S \epsilon \dot{\epsilon} \pi \pi 0 \lambda \dot{v} \alpha \tilde{\tau} \tau \eta \dot{\eta} \sigma \kappa \epsilon v \dot{\eta} \kappa \alpha \tau \epsilon \in \sigma \chi \nu$. (trans. Smith)

${ }^{253}$ Morris (1992) $151-152$.

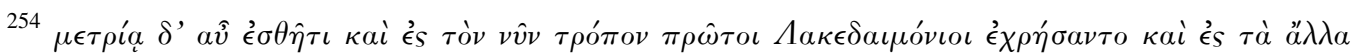

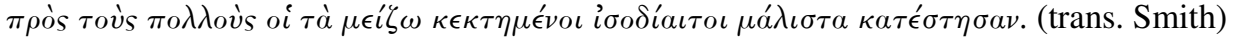

${ }^{255}$ Morris (1992) $151-152$.
} 
and etiquette. ${ }^{256}$ However the problem with this claim is that permanent grave markers do not have the same short useful life that grave goods have. ${ }^{257}$ Once a monument has been erected, it may stand for centuries. Standing monuments therefore present mortuary patterns that are not 'in a class with fashions in dress, luxuries and etiquette. ${ }^{258}$ Grave markers were not removed, except in times of war when they were required in order to build defensive walls. ${ }^{259}$ Therefore it seems unlikely that the halt in Athenian grave markers was linked to a change in fashion.

As overt signs of aristocratic wealth and influence diminished, the number of actual graves uncovered in Athens increased dramatically. As in the late eight century B.C.E., the rate at which Athenians seem to be burying their dead undergoes something of a 'quantum leap' rising from three per cent per annum in 500 B.C.E. to around nine per cent per annum in 450 B.C.E. ${ }^{260}$ The increase in burials indicates that burial was still important and so too citizenship, but less wealth was diverted to the funeral and markers, perhaps because it was seen as undemocratic. The result was a shift to a more collective ethos - the aristocracy had to be seen to be adhering to democracy even if they were still very much a part of the old elite. Expenditure on the dead had been very high on the list of a rich citizen's financial priorities, or at least should have been seen to have been:

\footnotetext{
${ }^{256}$ Canon (1989) 437.

${ }^{257}$ Grave goods are visible at the time of burial, but thereafter are buried with the deceased and are then no longer in view, unlike the grave marker.

${ }^{258}$ Small (1997) 150.

${ }^{259}$ Cannon (1989) 445.

${ }^{260}$ Whitley (2001) 366; 186 fig 8.10 provides a graph which outlines the growth in grave numbers between 950 B.C.E. and 700 B.C.E. a pattern which Whitley argues is repeated c. 430 B.C.E.
} 
for example, one family tomb erected in the last decade of the fifth century B.C.E. is reckoned to have cost at least 2,500 drachmae: 'for the father's tomb, though he did not spend twenty-five minae of the five thousand drachmae shown, he charges half this sum to himself, and has entered half against them', although the defendant actually claims that the true figure was twice that amount (Lysias 32.21). ${ }^{261}$ Lysias may have inflated the cost in order to make his case more persuasive, but the point remains that, before the switch to an intensely democratic ethos, lavish funerary expenditure was seen as an integral obligation of an elite oikos. As state ideology turned increasingly towards democracy, the lavishness of burials decreased.

\section{Votives}

As private sepulchral monuments declined, private sculptural dedications continued to be made in sizeable numbers on the Athenian Acropolis. (IG 810900). This ritual expenditure contrasts not only with the new restraint in funerary monuments but also with the lack of public building in sanctuaries between c. 480 and c. 450 B.C.E. It is tempting to see an inverted balance in expenditure between the cemetery, in which the polis now outshone the restricted individual by means of the state funeral, epitaphios logos and public funeral monument, and the sanctuary. At the sanctuaries, those citizens with the necessary resources could advertise their wealth by dedications whilst the great temples themselves lay in ruins; Stears suggests that the increase in votives was at the instigation of the Oath of Plataea. ${ }^{262}$ The rich could still dedicate costly

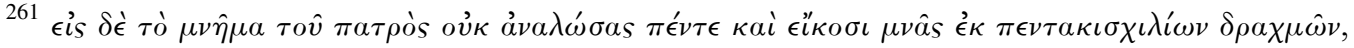

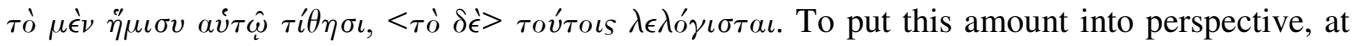
this time a rower in the Athenian navy earned one drachma per day. (Garland (1998) 120.)

${ }^{262}$ Stears (2000) 46; See pp. $73-74$. 
votive monuments, which could be viewed not only as pious acts by individuals (or clans) but also as embellishments of sanctuaries for the public good. Expenditure on liturgies in this period would also provide an access for selfadvertisement within the polis, but the loss of such a traditional arena for conspicuous consumption as the cemetery may have hit hard. ${ }^{263}$

Snodgrass, in his analysis of the emergence of the polis, has emphasised the importance of religious developments, the growth of communal sanctuaries in which was invested considerable wealth, a shift of attention away from the individual grave. ${ }^{264}$ Catherine Morgan has outlined what she sees as the gradual accretion of sanctuary and religious functions to the state. ${ }^{265}$ The formalisation of athletic contests and funerals represented a taming or curtailment of elite spheres of activity. The transfer of arms and armour from graves to sanctuaries represented an ideological statement of the place of military force in the state. ${ }^{266}$ Increased activity in sanctuaries during a time when spending on funerals was limited indicates that the elites were diverting wealth, not that there was a decrease in wealth. If this is the case then the elites actively chose not to spend dispensable income on burials as they had done in the preceding period to win favour. Instead, they tried to win favour through religious offerings, perhaps as a way to circumvent the laws attributed to Solon and the post aliquanto law which severely curtailed the archaic funeral. However there is evidence that the state also attempted to appropriate cults.

\footnotetext{
${ }^{263}$ Ibid, $46-47$.

${ }^{264}$ Snodgrass (1980) $52-65$.

${ }^{265}$ Morgan (1993) $26-27$.

${ }^{266}$ Shanks (1999) 175.
} 


\section{The Establishment of Cults}

As part of state appropriation of death, the state commandeered funeral celebrations. There is evidence that a state cult of the dead was established. As part of this cult, on one day a year a family would celebrate their dead. This celebration was called the Genesia. Some scholars, most notably Felix Jacoby, ${ }^{267}$ have suggested that Solon as part of his democratic reforms appropriated a festival called the Genesia ${ }^{268}$ once a private aristocratic celebration of the dead, and made it a state affair to be celebrated on a set day each year as a way of minimising the disturbance which was brought about by private celebrations.

The main evidence for this festival comes from the Antiatticista, a lexicon from the second century C.E. in which the following entry is found:

Genesia: was a festival held at Athens on the 5th of Boedromion paid for at the public expense, as Philochoros and Solon (on the axones) say, and since the use of the name is Hellenic, what prevents it from not only being applied ( $\tau \alpha \dot{\sigma} \sigma \sigma \epsilon \sigma \theta \alpha \iota)$ to the festival organized at public expense but also to the private feast of an individual $?^{269}$

The entry shows that the lexicographer knew two things: that there was a state festival in Athens called Genesia that was celebrated on the fifth of

${ }^{267}$ Jacoby (1944a) $65-75$.

${ }^{268}$ Simms (1997/8) 135.

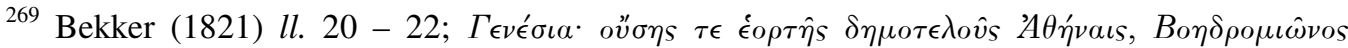

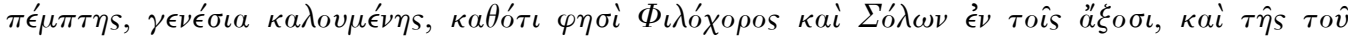

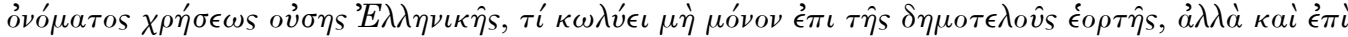

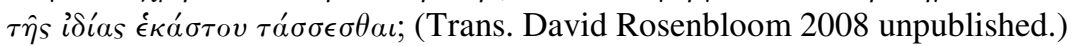


Boedromion; and that throughout Greece Genesia referred to a private festival but at Athens it was a public festival. It provides no information about the festival's character or purpose.

Herodotus provides further evidence of the Genesia and perhaps an indication as to its character, when he compares the burial customs and the cult of the dead practised by the Issedones with the Greek Genesia (4.26):

It is said to be the custom of the Issedones that, whenever a man's father dies, all the nearest of kin bring beasts of the flock and, having killed these and cut up the flesh, they also cut up the dead father of their host, and set out all the flesh mixed together for a feast. As for his head, they strip it bare and clean and gild it, and keep it for a sacred relic, to which they offer solemn sacrifice yearly. Every son does this for his father, just as the Greeks perform the Genesia. ${ }^{270}$

Through this comparison Herodotus provides two pieces of information: that both are festivals of commemoration celebrated annually and that both are affairs of the family and not, as at Athens, of the state. ${ }^{271}$

Hesychius, a fifth century C.E. lexicographer, provides further information about the nature of festival: 'Genesia: a festival of mourning for the Athenians.

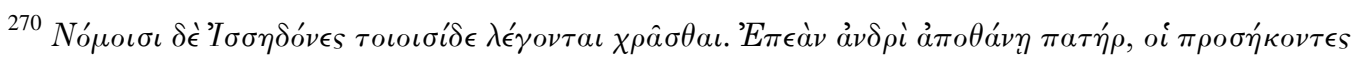

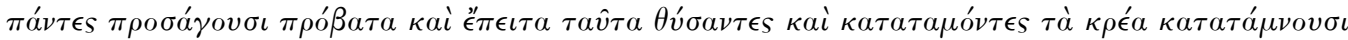

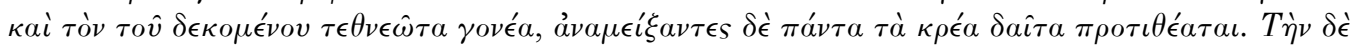

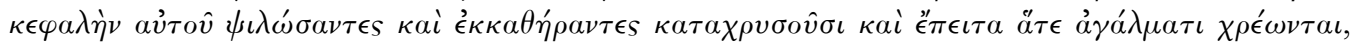

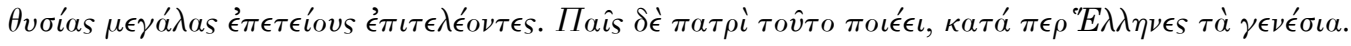
(trans. Godley - adapted)

${ }^{271}$ Jacoby (1944a) $66-67$.
} 
Others say the Nekusia. And on this day they make sacrifices to Ge. ${ }^{272}$ Hesychius records that the Genesia was concerned with mourning and that it was the occasion of sacrifices to Ge. He reports that the $\gamma \epsilon \nu \in \epsilon^{\prime} \iota \alpha$ was also called the $\nu \epsilon \kappa v ́ \sigma \iota$. Lambert believes that $\nu \epsilon \kappa \dot{v} \sigma \iota a$ could be an allusion to the private rite, and that perhaps Hesychius' source was Herodotus. ${ }^{273}$

A final piece of conjectural evidence which came to light post-Jacoby is a text which, although not precisely the axon referred to in the Anecdota, may nevertheless, according to Lambert, stands in quite close relation to it. It is part of Fragment 1 of the sacrificial calendar of Athens, probably inscribed in the second phase of work on the legal review commission of Nikomachos, 403/402400/399. ${ }^{274}$ Little survives of the inscription, and of that little, much is conjectural. $^{275}$ The fragment tells that there was a sacrifice of a ram to Erechtheus by the 'tribal kings' and possibly the sacrifice of a pig to some divinity on the fifth of some month and perhaps a wineless offering was made. ${ }^{276}$ There is no provision for a hierosyna, therefore it is possible that the offering would have been a holocaust. ${ }^{277}$ The fragment refers to the Phylobasileis, the tribe kings who were the four heads of the old Ionian tribes, which at the date of the inscription would have been superseded a hundred years earlier by the ten tribes of Cleisthenes, an indication that the festival had much

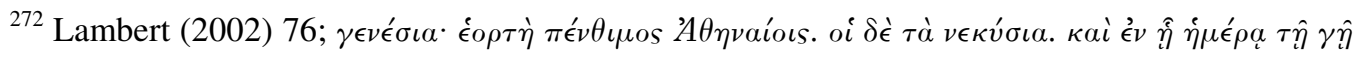

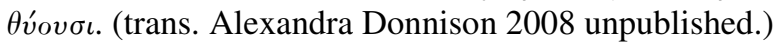

${ }^{273}$ Lambert (2002) 76; Jacoby (1944a) 74; Other late sources are also listed by Jacoby (1994a) $74-75$, but add little except reaffirming the claim that the rite was annual and was not the same as $\Gamma \epsilon \epsilon^{\prime} \theta \lambda_{\iota \alpha}$ (birthday).

${ }^{274}$ Lambert (2002) 76.

275 Ibid.

${ }^{276}$ Hansen (1990) 51.

${ }^{277}$ Ibid.
} 
older roots. As the festival alluded to occurred on the fifth of the month, Lambert has linked this fragment to the Genesia. ${ }^{278}$ If this fragment does refer to the Genesia, it would indicate, as both Dow and Lambert contend, that the Genesia was a small and ancient festival, ${ }^{279}$ and that it therefore predates Solon. The assertion that the festival was small with ancient roots is probably correct, and does add some merit to associating this fragment with the Genesia, however the fragment is badly preserved and the evidence for the association is at best circumstantial.

The sources provide such little detail about the festival that even the meaning of the name remains uncertain. A scholiast recorded that it related to $\Gamma \epsilon \nu \epsilon^{\prime} \theta \lambda_{\iota \alpha}$ (birthday) but as shown by Jacoby this association is wrong. ${ }^{280}$ Jacoby accepts the definition suggested by Schmidt that $\gamma \epsilon \nu \epsilon^{\prime} \sigma \iota \alpha$ relates to $\gamma \epsilon \nu \epsilon^{\prime} \tau \alpha \iota$, therefore 'the Genesia is the festival of the fathers (or ancestors), not Natalicia but Parentalia. ${ }^{281}$ Jacoby ties the $\gamma \epsilon \nu \epsilon ́ \sigma \iota \alpha$ exclusively to the gene which he takes to be an aristocratic family. Bourriot and Georgoudi correctly reject the theory that the Genesia had to do specifically with the gene and that a democratising Solon, in instituting a state Genesia, was making available to all what had been a ritual specific to aristocratic families, as there is little evidence that it had previously been exclusively for the aristocrats or linked specifically with gene. ${ }^{282}$ Johnson suggests the name implies 'begetters' and therefore was probably a ritual performed by children for their dead parents and perhaps grandparents and more

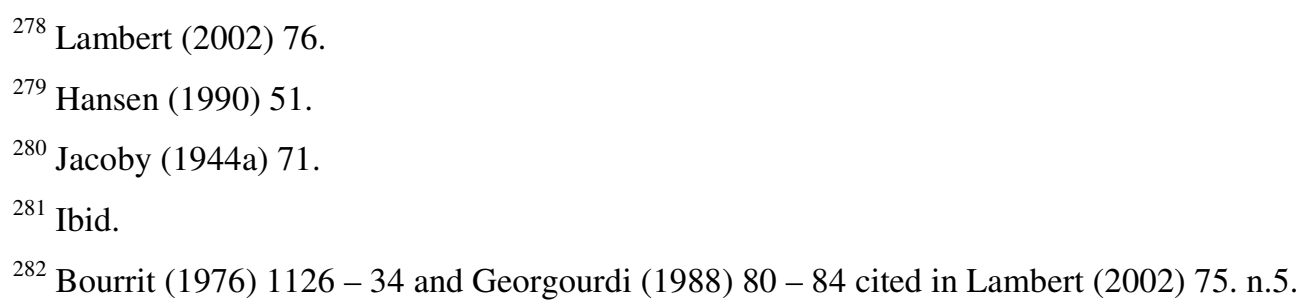


distant ancestors. This meaning is further borne out by Herodotus' use of the word - he uses the Genesia as an analogy for Issedonian funeral practices performed by sons for their fathers. ${ }^{283}$ Johnson's interpretation fits in with the most current etymological interpretation, put forward by Lambert that Genesia is 'to do with $\gamma$ '́ $v \in \sigma \iota s$, birth, parenthood or origins more generally. 284

There is another spurious reference, omitted by Jacoby, which some scholars, such as Lambert, Johnson and Parker, link to the Genesia. ${ }^{285}$ It comes from Demosthenes (41. 11), where the speaker says his wife had advanced a mina 'to the nemesia of her father'. ${ }^{286}$ Parker suggests that $\nu \epsilon \mu \epsilon$ б $\iota$ can be taken as an early corruption of the more likely $\gamma \epsilon \nu \epsilon^{\prime} \sigma \alpha^{287}$ It seems unlikely that it is a corruption as $\nu \epsilon \mu \epsilon \in \sigma \iota$ could refer to another event such as the $N \epsilon \mu \epsilon^{\prime} \sigma \iota \alpha$ held in the Attic deme, Rhamnous.

The public Genesia was probably celebrated on a set day each year, as suggested by Jacoby, ${ }^{288}$ although there is no evidence that Solon himself chose the date. Herodotus' words do not necessarily imply that individual choice of date was the practice in his day outside Attica, and Genesion is known as the name of a month at Magnesia on the Maeander which should imply a fixed time for the Genesia in the city. ${ }^{289}$ However Jacoby in any case made an important

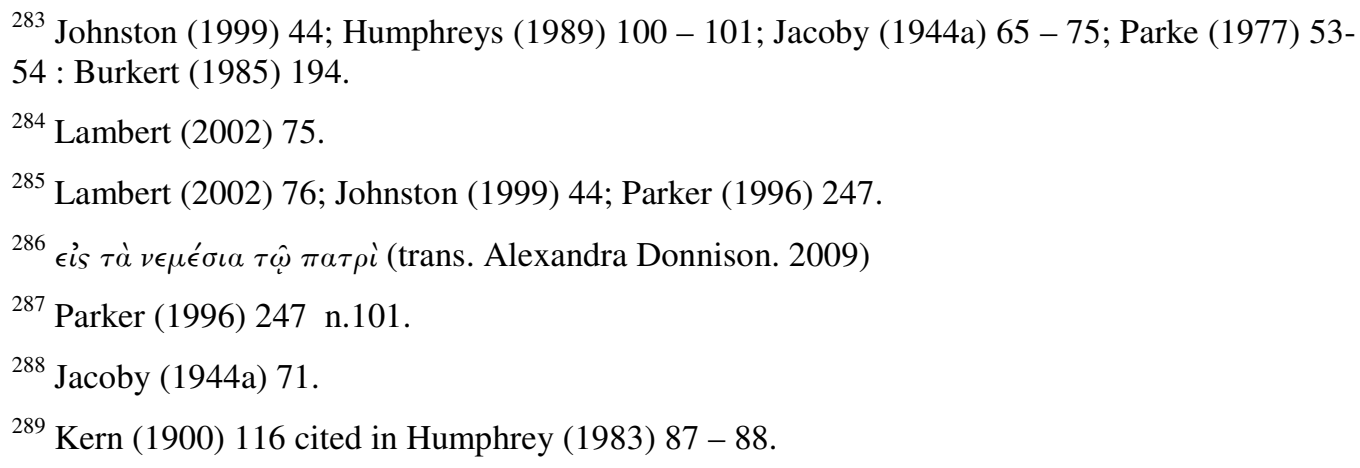


point in stressing that a fixed date for the festival implied that each individual could only attend commemorative rites in a single cemetery. ${ }^{290}$ The scope for gratifying powerful relatives or friends by attending their family rituals was limited by duties to one's own immediate ancestors, and only those ancestors who were buried together would be commemorated. The effect would be that those who felt strongly about the duty to honour all their ancestors would need to ensure that all members of the family were buried together, but the evidence for large-scale and long-lasting groupings of this kind are rare.

If Solon had instituted the public Genesia it would have been a good way of limiting aristocratic displays of wealth and disruption to the polis, an argument first proposed by Mommsen and further explored by Jacoby. ${ }^{291}$ They believed that Solon established the festival as a state affair in order to limit the clans by 'deliberately subjecting their barbarously extravagant character to Attic

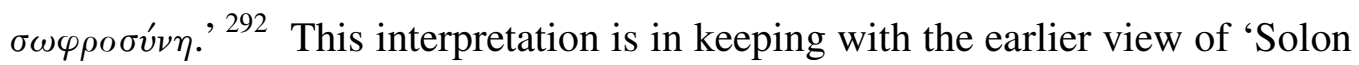
the Lawgiver' who was viewed as powerful and as using this festival along with his laws to target the excesses of the upper classes, but as I argued above, these laws were unlikely to have limited the excesses of the clans and similarly the Genesia as a state festival is unlikely to have had a dramatic effect on the clans, as there is no recorded provision which prohibits private celebration. ${ }^{293}$ It is more likely that the Genesia was an ancient and small festival, which perhaps did grow to become a bigger affair; hence it was noted on an axon of Solon, but

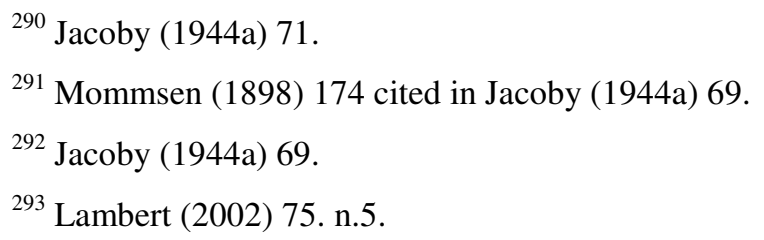


that it grew of its own accord and was appropriated by Solon to limit the aristocracy. As part of this festival the state would more than likely put on funeral games. ${ }^{294}$ These state sanctioned games would have been a bigger event than a single clan could have afforded to hold, and would have helped the state create a collective ethos. ${ }^{295}$ Such an appropriation of a private festival by the state would be in keeping with the times, a shift from the individual to the collective, and would also be within the spirit of the surviving Solonian laws.

\section{The Persian Wars}

Richter put forward an idea which she terms 'a perfectly natural explanation' for the disappearance of the lavish grave markers, namely the looming invasion by Persia, the War, the destruction wrought by the Persians and finally the Oath of Plataea. ${ }^{296}$ This explanation is too simplistic, in that it may explain a short halt in the production of grave markers, but does not explain the long-term trend in either Athens or throughout Greece.

The Oath of Plataea seems to point to a sentiment of the time, one where defence was paramount and there was no time or resources allocated to rebuilding and repairing sanctuaries. This could imply, as Richter seems to hint at, that instead of time being dedicated to funeral monuments it was redirected to defence. ${ }^{297}$ The Oath of Plataea, said to have been sworn in 479 B.C.E. by the

\footnotetext{
${ }^{294}$ Loraux (1986) 30, a lebes has been found which was a reward offered around 480 B.C.E. to the winner of a competition celebrated by the Athenians in honour of the war dead.

${ }^{295}$ See Seaford (1994) 120 - 123 for further discussion on the funeral games, in particular their relation to hero-cult.

${ }^{296}$ Richter (1961) 53.

${ }^{297}$ Ibid.
} 
Greeks, stated that they would fight to the death, remain loyal to their commanders and allies, and perhaps most crucially not rebuild any temples destroyed by the Persians, leaving their remains there as a memorial to barbarian impiety. ${ }^{298}$ The problem with the Oath is that there are several different versions and its authenticity has been called into question since the fourth century, and modern scholars mainly view it as apocryphal. ${ }^{299}$ It is difficult to see why the Spartans would have sworn not to rebuild temples destroyed by the Persians since the Persians never managed to destroy anything in the Peloponnesos. ${ }^{300}$ The Oath most likely reflects what later writers assumed the sentiment of the time to be. ${ }^{301}$ It is hard to see why Richter links this oath with the decline in funerary monuments - it may explain why sanctuaries were not rebuilt, but does not apply to nor explain the growing restraint being shown in burial practices. ${ }^{302}$ The Oath does show that conditions in Athens had changed, but not enough to dissuade all of the wealthy Athenians from erecting expensive private monuments. ${ }^{303}$

\footnotetext{
${ }^{298}$ Hurwit (1999) 141; Fine (1983) 323.

299 Richter (1961) 53; Fine (1983) 323; The earliest ancient source is Herodotus 7.132. Lycurgus, the Athenian orator in his speech Against Leocrates 80-81 dated to 330 B.C.E quotes the oath. There is also an inscription found in Menidi in 1932 which has been associated with the Oath of Plataea. Diod. 11.29.3. Theopompus (FGrH 115 F 153) denounced it as an Athenian invention and it appears that the Oath suffered the same revisionist fate that the laws of Solon did. : Rhodes and Osborne (2003) 440 - 449 (88) provide a good discussion of the Oath and its historicity.

${ }^{300}$ Hurwit (1999) 141.

${ }^{301}$ Richter (1971) 53.

${ }^{302}$ Boardman and Kurtz (1971) 121, state that the absence of relief gravestones in Athens need not be related to any decision of the Athenians (the Oath of Plataea) to suspend all sacred building until Greece was free as there were grave markers of other types.

${ }^{303}$ As noted in Chapter One (pp. 34 - 35) there are some notable exceptions to the decline in funerary moments, showing that some family groups clearly chose to ignore the prevailing sentiment of restraint.
} 


\section{Legislation}

Another explanation that has been mooted for this change is 'sumptuary' legislation. ${ }^{304}$ The opposing views taken by scholars towards this legislation were outlined in chapter one, where I argued that the fact these funeral laws were recorded demonstrates that there was a change happening in Athens regarding funerals. The issue of whether the laws were a catalyst or a reaction is hard to establish, and what we must take from these laws is that society deemed it necessary to legislate, ${ }^{305}$ and that, as Morris argues, these laws are not to be taken as the sole reason for the change - that approach is far too onedimensional. If the laws of Solon and the post aliquanto law did limit the funeral then why, if there is no record of their repeal, did grand funerals reemerge in the Classical period? Clearly the forces behind the change are more complex than merely the passage of laws. ${ }^{306}$

As Solon's laws were examined closely in chapter one, it should suffice here to give a brief overview of how they affected funeral practice in Athens. ${ }^{307}$ Solon's law as reported by [Demosthenes], Plutarch and Cicero decreed that the prothesis was to be held inside, and that the ekphora was to take place on the next day before sunrise with the men walking in front and the women behind.

${ }^{304}$ The laws, I argue, are not actually sumptuary. See n. 209.

${ }^{305}$ Blok (2006) 240 states that: 'No relationship between the post aliquanto-law and funerary monuments, nor between this law and other archaic funerary laws can be established in any satisfactory way.' This is a polemic view. I, however contend that the laws did exist, and that they could potentially have had an effect on funerary practices, but they are not a complete explanation, and most likely reflect a common societal impulse rather than themselves having a direct effect.

${ }^{306}$ Morris (1992) 147.

307 See Scafuro (2006) 175 - 196 for a detailed discussion on identifying Solonian laws and Blok (2006) 197 - 247 for a detailed study on Solon's funerary laws, particularly the breakdown of the laws on 219. 
The participation in the prothesis and ekphora was to be limited either to women within the degree of second cousin or to those who were over sixty years of age, the former group being allowed the additional privilege of returning to the house after the body had been removed. No restrictions were placed upon the attendance of men. ${ }^{308}$ The reported laws limited the size and therefore the spectacle of the funeral, but no limit on how much money could be spent on the funeral or specific aspects of the funeral is recorded, and therefore the laws are not strictly sumptuary as scholars have claimed. ${ }^{309}$

Solon's restrictions on funerary ostentation referred only to burial, but a law referred to by Cicero as the 'some time later' (post aliquanto) law was passed, stating that no grave monument was to be more elaborate than the work of ten men could accomplish in three days, that tombs were not to be adorned with opus tectorium or have 'herms' (hermae) erected on them, and that the dead were not to be praised except in public funerals by the orator officially appointed for the task (Appendix 1: 4c). Opus tectorium, in the view of Boardman, ${ }^{310}$ would refer to painted plaques hung round built tombs in the sixth century which provided a permanent representation of the funeral and its various stages; 'herms' seems to be a general term for any standing stone grave marker. ${ }^{311}$ Archaeologists agree that there is a change in Attic burial practice corresponding to this law, although they disagree on the exact date within the

\footnotetext{
${ }^{308}$ Seaford (1994) 75; Garland (1989) 3.

${ }^{309}$ See n. 209.

${ }^{310}$ Boardman (1955) 53.

${ }^{311}$ Ibid.
} 
period c. $510-480$ B.C.E. to which the change should be assigned. ${ }^{312}$ Stone stelae are not clearly attested archaeologically after this period, apart from those noted in Chapter One, until the time of the Peloponnesian War (431 to 404 B.C.E.).

The recorded laws seem to have focussed particularly upon the role of women. The primary sources tell us that the limitations on the participation of women were designed to control an unruly element in society: Plutarch states that women should not be encouraged to give their emotions free reign (Moralia, 609a ff.), whilst Lysias and Terence explore the (invariably disastrous) consequences of women meeting non-kin men at funerals. (Lysias 1.8; Terence, Phormio 91-116). ${ }^{313}$

Scholars have built on the ancient tradition, particularly evident in Plutarch's account of Solon's laws (Plutarch, Solon 21 (Appendix 1: 3)) of viewing these laws as focusing on women. Holst-Warhalf, Humphreys and Stears all offer feminist analyses of this Solonian legislation, and all three see it as focused on controlling women and their participation in the funeral. Holst-Warhaft argues that the laws clearly limit women's prominent role in the rituals, particularly their loud laments as they passed through the streets of a town, which, though a custom traditionally accepted, were becoming challenged during Solon's archonship. ${ }^{314}$ Stears states that the laws specifically stipulated the roles and expectations of women at funerals, but then goes on to argue that the legislation

\footnotetext{
312 cf. Stupperich (1977).

${ }^{313}$ Humphreys (1993) 86.

${ }^{314}$ Holst-Warhaft (1992) 115.
} 
should not be taken as being specifically aimed at women even though they were the central producers of noisy lamentation at the funerals. ${ }^{315}$ Humphreys states that convention required that men should maintain self-control in mourning, ${ }^{316}$ whereas women were encouraged to display wild grief: therefore to restrict female participation in prothesis and ekphora to kin and women over sixty markedly reduced both the aural and visual impact of the procession.

In all cases women are especially singled out by the restrictions. At Athens the emphasis is on the banning of offerings at the grave and the limitation of the right to mourn to kinswomen, but the extension of the laws to other women's activities, and the comments of the later Greek theorists, suggest that women were the special targets of the legislation. ${ }^{317}$ The surviving law codes of Ceos and Delphi also have many provisions that were aimed primarily at women. There can be no doubt that the task of mourning the dead fell chiefly to the women, whose displays of grief, unless checked, might amount to a social nuisance. $^{318}$

The establishment of an annual public funeral for the dead (Genesia) may have directly impinged upon women's ritual authority within the oikos. With no corpse to care for (as the dead were cremated on the battlefield) and with the lamentations effectively suppressed by the institution in the early fifth century

\footnotetext{
${ }^{315}$ Stears (1998) 117; Stears (2008) 143.

${ }^{316}$ Humphreys (1993) 86; It is noteworthy that no restrictions were placed upon the attendance of men. Morris (1989) 3. It may be due to their already expected stoic behaviour that the lawgivers saw no need to legislate the role of the male, as it did not draw attention to the spectacle of the funeral like the female mourning style did.

${ }^{317}$ Holst-Warhaft (1992) $114-115$.

${ }^{318}$ Garland (1989) 5; Social disprution caused by mourning is still a concern in modern day Greece; see O'Rourke (2007) 397 for further discussion.
} 
of a state funeral speech, the epitaphios logos, they were handicapped to the level of silence. As with the funerary legislation enacted by Solon and others, when the polis wished to curtail the powers of kin groups in death ritual it struck out at its most vociferous members - its women. ${ }^{319}$

\section{The Growth of Democracy: Public Burial and the Demosion Sema}

Perhaps the most favoured argument as to why private funerals declined is the shift in focus to the polis, from the individual to the collective, and the beginnings of democracy. It is true that the disappearance of archaic sculpted funerary monuments coincided with the arrival of democracy, and it is not difficult to see that the young democracy might view these commemorations of the lifestyle of men (and occasionally women) as potentially divisive, points around which family groups might have rallied with politically subversive intent. $^{320}$

Humphreys suggests that the development of state burial first brought the honours of heroic burial within the range of every Athenian citizen. ${ }^{321}$ Whitley argues that democracy acted as a kind of 'levelling ideology', which made it imprudent for anyone to unduely stress any superiority in wealth or birth. ${ }^{322}$ Everyone, in theory, in death at least was equal; parsimony in grave goods, and plainness in sculptural expression, therefore came into favour. ${ }^{323}$ But soldiers

\footnotetext{
${ }^{319}$ Stears (2008) 148.

${ }^{320}$ Osborne (1997b) 27.

${ }^{321}$ Humphreys (1993) 89.

${ }^{322}$ Whitley (2001) 366.

${ }^{323}$ Ibid.
} 
were set apart in death. If they fulfilled their obligation/right to fight and died they were glorified with state burial and through the words of the epitaphios logos were memorialised. However, this special treatment partially lessens any apparent equality being brought about by democracy. If anything the democracy set up a different kind of superiority, replacing the aristocratic monopoly with its own. Family links and family claims to fame had traditionally been a basis for asserting political power; the democratic city had an interest in the nature of funerary display. Because claims to belong to the city, like claims to belong to a particular family, depended on descent and hence on marriage, politically acceptable marriage and politically acceptable domestic relations needed to be promoted. ${ }^{324}$ High profile marriages between Athenian elites and the elites of other Greek cities ceased more or less at the same time funerary sculpture disappeared and democracy rose.

Meyer argues that the key reasons for the transition in burial practices were the public funerals and public monuments favoured by the Athenians in the fifth century. ${ }^{325}$ For at some time early in the fifth century Athens not only limited what individuals or families could do but also instituted state monumental commemoration on stone between c.490 and 430 B.C.E. The grave-stelae that survive from these public burials list Athens' war-dead by tribe, battle and individual name, were sometimes accompanied by an epigram, and were erected in the Demosion Sema in the Kerameikos. ${ }^{326}$

\footnotetext{
${ }^{324}$ Osborne (1997b) 28.

${ }^{325}$ Meyer (1993) 108.

${ }^{326}$ Ibid.
} 
The Athenians were unique among the ancient Greeks in the burial of their war dead. These they interred not, like the other Greeks, on the battlefield where they fell, but in a common grave in their public cemetery, the Kerameikos. ${ }^{327}$ However no actual war grave has been found. ${ }^{328}$ The origins of the state funeral are disputed, and still remain somewhat obscure. Morris suggests state funerals grew up gradually from c. 500 B.C.E., ${ }^{329}$ Jacoby claims that the ceremony was instituted in 465 B.C.E ${ }^{330}$ Clairmont argues that the custom of burying the dead at public expense in the Demosion Sema began in the late 470's or early years of Cimon's reign. ${ }^{331}$ Nightingale claims that 'historians now believe that the "demosion sema" ... 'and the epitaphios logos were first established around 470 BC. ${ }^{332}$ The only detailed description of the Demosion Sema comes from Pausanias, who wrote in the second century C.E. He described the state graves in what appears to be a roughly topographical order (1. 29), but his account is not accurate, nor could it be. Even if he used the fourth-century topographer Diodorus Periegetes, the terrain of the Kerameikos had already, by the time of Diodorus, suffered alterations by human and natural means. ${ }^{333}$ It appears that, at least initially, a portion of the Academy road was set aside for the burial of

${ }^{327}$ Walters (1980) 1; The term 'public burial' refers to burial where the cost is borne by the State, it is held in a public context or public audience, and the bones or corpse are deposited in a public place or tomb. Patterson (2006b) 21; Morris (1992) 146, other poleis normally buried their dead on the battlefield.

${ }^{328}$ Clairmont (1983) 60 - 73; For further details on war burial see Pritchett (1985) $94-259$.

${ }^{329}$ Morris (1992) 131 n.3.

${ }^{330}$ Jacoby (1944a) $65-75$.

${ }^{331}$ Clairmont (1983) 13; Demosion Sema to my knowledge is only used once, in Thucydides (2. 34) and then only this once. This has led some, such as Patterson to question whether there actually was 'a national cemetery' and argue that the Demosion Sema is actually a modern construct. Patterson (2006a) $54-55$.

${ }^{332}$ Nightingale (1995) $95-96$.

${ }^{333}$ Kurtz and Boardman (1971) 108 - 109. By the middle of the fourth century the horoi along the Academy Road had been raised to compensate for the rising ground level, a decade later the tombs were sacrificed for the defence against Philip (Aeschines Ktesiphon 236); a layer of rubble and brick bears witness to the destruction. 
foreign casualties and must therefore be separated from the Demosion Sema proper. $^{334}$

Evidence for 'public' funerals goes back to the origins of the polis. In the seventh century the Corcyreans buried a proxenos from Oiantheia in the Corinthian gulf at public expense. ${ }^{335}$ The Athenians gave a public funeral to Pythagoras of Selymbria in the middle of the fifth century, and may have done the same earlier for other benefactors such as Solon and Tellus. ${ }^{336}$ Public burial is confirmed by literary evidence for both Solon and Tellus. The sources use the term $\delta \eta \mu о \sigma i \eta \eta$. According to one version, Solon's ashes were scattered over the island of Salamis. If the story is true, the tomb of Solon in front of the Dipylon Gate referred to by Aelian (Hist. Misc. 8.16) can only have been a cenotaph. According to Herodotus (1.30.5) Tellus 'died very Finley. The Athenians buried him at public expense on the spot where he fell and gave him much honor.' ${ }^{337}$ The date of Tellus' death falls into the $6^{\text {th }}$ Century. The formula $\alpha \dot{v} \tau o \hat{v} \tau \hat{\eta} \pi \epsilon \rho \stackrel{\prime \prime}{\epsilon} \pi \epsilon \epsilon$ exemplified on-the-spot burial and one should like to know whether Tellus was the only casualty in the warfare in Eleusis, ${ }^{338}$

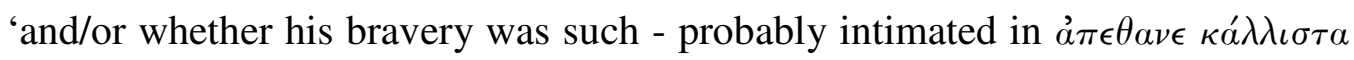
- that the Athenians found reason to 'honour him greatly' after death. ${ }^{339}$ The

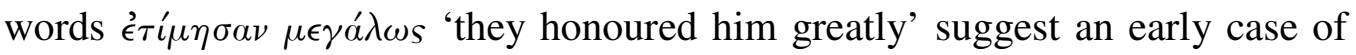

\footnotetext{
${ }^{334}$ Clairmont (1983) 31.

${ }^{335}$ Ibid.

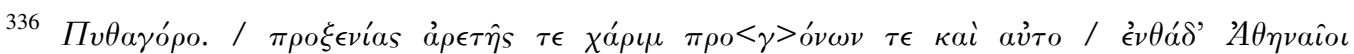

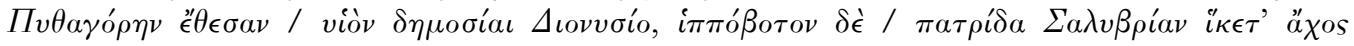

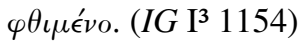

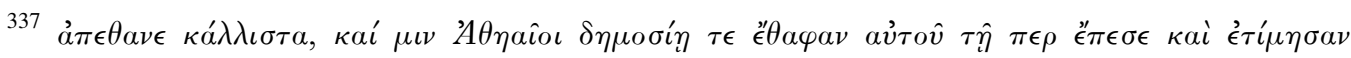
$\mu \epsilon \gamma a ́ \lambda \omega s$. (trans. Godley)

${ }^{338}$ Patterson (2006b) 21.

${ }^{339}$ Clairmont (1983) 31.
} 
public hero-worship in the historical period, commonly attested to in Greek epic, but became a state concept only with the casualties at Marathon. ${ }^{340}$

Thucydides (2.34) described in some detail what the patrios nomos consisted of: the state burial takes place at a specific time of the year. The bones lie in state for three days. A tent is erected for this purpose. The relatives bring offerings to the dead. There are ten larnakes of cypress wood for the bones (and ashes), one for each tribe. An eleventh larnax is provided for those casualties whose bodies could not be recovered. Anyone may take part in the homage to the dead, citizens and, more interestingly, foreigners. Women related to the dead make lamentations. After the larnakes are buried a man chosen by the city-state pronounces the epitaphios logos. After that all depart. ${ }^{341}$

The war graves had altar-like dressed stone monuments topped with statues and ten inscribed stone casualty lists, and at least in 394 B.C.E., a sculpted frieze. ${ }^{342}$ The earliest casualty list known is for the Drabescus campaign of 464 B.C.E.,

\footnotetext{
${ }^{340}$ Clairmont (1983) 8; Patterson (2006b) 21.

${ }^{341}$ Clairmont (1983) 12. It is believed that Thucydides wrote the passage about the Patrios Nomos at the very end of the Peloponnesian War, some seventy to eighty years after the Persian

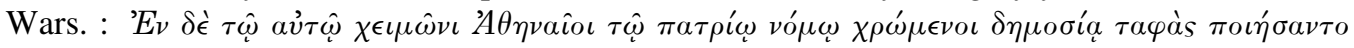

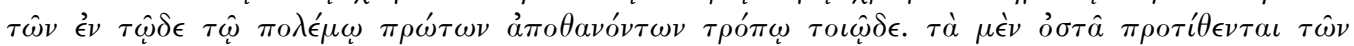

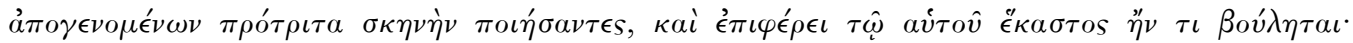

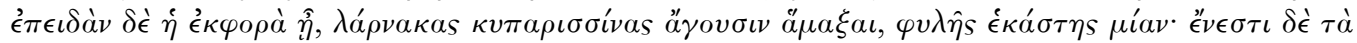

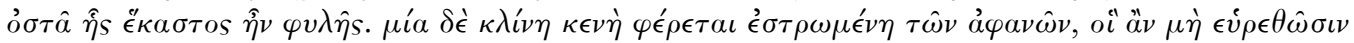

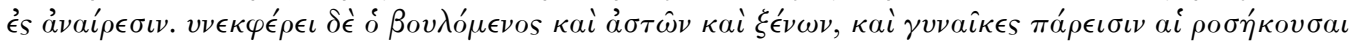

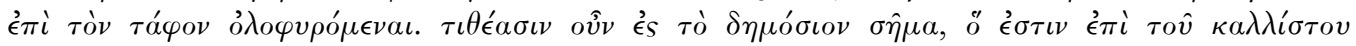

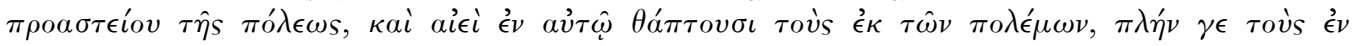

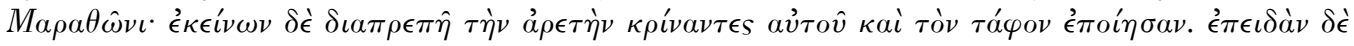

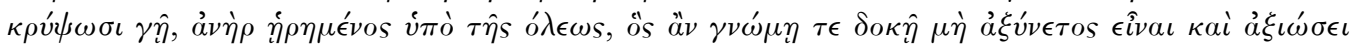

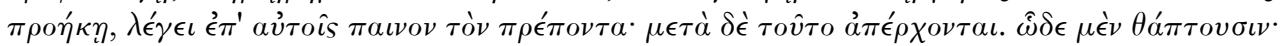

${ }^{342}$ Whitley (2001) 365 argues that the stelae set up with the names of the war dead on them are misleadingly referred to as 'casualty lists' as if they were set up by some Athenian Ministry of Information, intent that the public be kept abreast of Athens' wars abroad. Morris (1992) 131.
} 
although some fragments may be earlier. ${ }^{343}$ Pausanias (1.29.24) says that the Drabescus tomb was 'the first', but it is not clear whether he means first in date or the first to be seen on leaving the city. Public commemoration in the fifth century was a major event, as descriptions of it, especially of the funeral oration and its consequences for individual habits of commemoration, make clear.

All fallen soldiers were honoured in the same way: they were listed on the stelae with their names in accordance with their phylae. Sometimes the names of foreigners, metics, and even in a few cases of slaves, were added. ${ }^{344}$ Stone stelae (of which fragments of some thirty have survived) inscribed with the name of the war dead from each tribe include in a number of cases the names of foreigners and even an occasional slave. ${ }^{345}$ Cleruchs who served along with their tribes, even though living on allied soil, are normally included in Athenian casualty lists. ${ }^{346}$ A part of the Academy road was set aside for the burial of foreign casualties, therefore it was probably separated from the Demosion Sema proper. $^{347}$ This evidence shows that foreigners were allowed to bury and celebrate their dead in Athens; therefore burial in Athens was not a defining feature of Athenian citizenship.

\footnotetext{
${ }^{343}$ Morris (1992) 131 n.3; Bradeen (1969) 154; cf. Loraux (1986) 29 who believes that there is no solid foundation for dating the State funeral to 464 B.C.E. She argues that too much weight has been placed on the evidence of Pausanias who reports that the Drabescus tomb was the first (1.29.4.)

${ }^{344}$ Stupperich (1994) 100.

345 See Bradeen (1969) 145 - 159.

346 Smith (1919) 358; Clairmont (1983) 50, 'On the earliest known casualty list Athenian Kleruchs who made their home in Lemnos were listed according to tribe.'

${ }^{347}$ Clairmont (1983) 31.
} 
Public burials were not just reserved for ambassadors and the war dead. At the other end of the social scale were those who, according to the author of the Athenian Constitution, died in the street (Ath. Pol. 50.2). These were the responsibility of the astunomoi, who used public slaves, demosioi huperetai, to pick up and dispose of the bodies. ${ }^{348}$ Presumably no distinction would be made between the corpse of a citizen or a non-citizen. It was the legal responsibility for the oikos to bury their own dead, ${ }^{349}$ so presumably some effort was made to track down the family of the deceased. ${ }^{350}$

State funerals in Athens limited the role the members of the oikos could play in the burial of their dead. The state burials were placed in the most prestigious part of the city, the Kerameikos, and would have attracted a lot of public attention. The growing democracy used this interest to focus the attention of the demos and cultivated a collective ethos. It was the state that was now the target of the collective focus: the ideology of death had shifted from being a private affair to a public 'celebration' of Athens. This growing ideology was reinforced through the use of the epitaphios logos.

\section{Epitaphios Logos}

The most outstanding feature of the public burial was 'the funeral oration recited annually each winter over those who had died in the previous summer's

\footnotetext{
${ }^{348}$ Patterson (2006b) 22.

${ }^{349}$ Hame (2004) 514, 516.

${ }^{350}$ Ibid; See Demosthenes 43. 57 - 58 .
} 
campaigns. $^{351}$ The epitaphios logos comprised a genre of literature that provides us with unusual access to the concerns and issues of Athenian society. The direct evidence spans the years $465-322$ B.C.E. ${ }^{352}$ The earliest extant fragment of a funeral oration is Pausanias 1.29.4-5. There are fragments of Pericles' epitaphios from the Samarian War. ${ }^{353}$ Surviving are those of Pericles (Thuc. 2.35-46) c. 430 B.C.E.; Lysias 2, c. 392 B.C.E.; Plato, Menexenus, c. 386 B.C.E.; Demosthenes 60, c. 338 B.C.E.; Hyperides 6, c. 322 B.C.E. Meyer has shown that Herodotus 7.161 and 9.27 derive from the epitaphic tradition. ${ }^{354}$ However, military commanders had presumably made funerary speeches before cremating war dead on the battlefield from early times: it would be from this custom that the polemarch, the original commander-in-chief of the Athenian army, derived his responsibility for the annual ceremony for war dead in the Kerameikos. Thus, the concept of the public funeral as a tribute paid by the polis to those deserving special honour had developed much earlier, but was made more prominent in the fifth century by burying the war dead in the Kerameikos from at least the time of the Persian Wars and continuing throughout the fifth and fourth centuries B.C.E. ${ }^{355}$

The ostensible purpose of the funeral oration was to eulogise the dead, but in fact it acted also as an encomium on the city itself. The epitaphioi reveal how

\footnotetext{
${ }^{351}$ Walters (1980) 1.

352 Ibid : Loraux (1986) 4, points out that there is no trace of the epitaphios logos after 322 B.C.E.

${ }^{353}$ Webster (1922) 375 - 95 cited in Walters (1980) 19. n.3.

${ }^{354}$ Meyer (1889) 219 ff. cited in Walters (1980) 19. Also related are Isocrates' Panegyricus and Panathenaicus and Aelius Aristides' Panathenaicus. Still further material can be found scattered in the historians, orators, and tragedians. Walters (1980) 19.n.3; For further discussion see Frangeskou (1999) 316 - 321.

${ }^{355}$ Walters (1980) 1.
} 
the Athenians pictured to themselves their city's merits and achievements, its present policy and past actions. ${ }^{356}$ The speakers were selected by the democratic city council, themselves chosen for office by blind lot, and voted upon by the assembly. Their qualifications were not oratorical or intellectual brilliance, but political respectability. ${ }^{357}$

The content of the speeches was remarkably static: traditional themes and exempla were recited with little or no change year after year in speech after speech. ${ }^{358}$ That the valour of the citizens killed in battle perpetuates the virtue and timelessness of Athens as a community of warrior equals, and that the Athenians, the only Greeks born from soil, are citizens of the greatest and truest of all poleis are common motifs. ${ }^{359}$ Athens, through the epitaphios logos, gave the same honours to her andres agathoi as are given to the heroes in the Iliad. In epitaphios speeches of the late fourth century, the fallen warriors are addressed as ones who have departed to the island of the blessed (Dem. 60.34, cf. Hyper. $6.35-39) .{ }^{360}$ The state appropriated ideals from Homeric Epic, such as the heroic death and timeless glory, and applied them to its fallen soldiers, akin to how the aristocrats had taken Homeric symbolism and applied it to their dead. 'The orations were designed not to inform or to innovate, but to articulate in ritual fashion shared community ideals, values, and attitudes - a true vox populi: it promulgated a message that was not the personal expression of the orators, but rather the collective voice of the Athenian polity. In particular, they

\footnotetext{
${ }^{356}$ Ibid.

${ }^{357}$ Ibid.

${ }^{358}$ Morris (1992) 131.

${ }^{359}$ Ibid.

${ }^{360}$ Stupperich (1994) 98.
} 
expressed and sought to resolve troubling inconsistencies and contradictions that were the legacy of Athenian culture and history.' 361

A frequent claim in the epitaphioi is to Athenian primacy and uniqueness $(\pi \rho \hat{\omega} \tau о \iota \kappa \alpha i \mu o \hat{v} \circ \iota)$. This refrain is repeated tirelessly. Athens is first in a variety of accomplishments or virtues. Athens differs from and thus excels all other Greek cities: Athens stands alone and is unique. One common claim, which appears in Herodotus, Thucydides, Lysias, Plato, and Demosthenes inter alios, is that Athens all by herself repulsed Darius' invasion at Marathon. ${ }^{362}$ Further Lysias tells us (2.18) that the early Athenians were the first and only

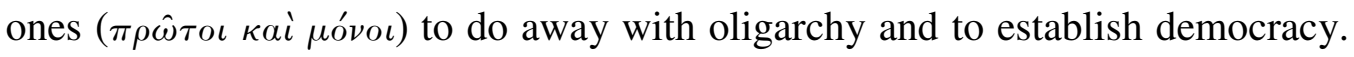
Plato points out (Menex. $237 \mathrm{E}$ ) how Athens had been the first and only country

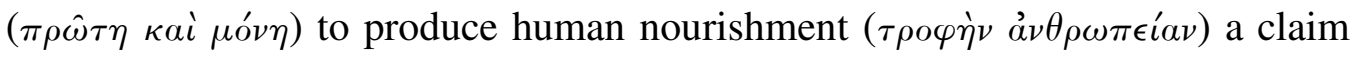
repeated by Demosthenes (60.5). Pericles asserts that the Athenians are at the opposite end of the spectrum from the majority in doing good deeds (Thuc.

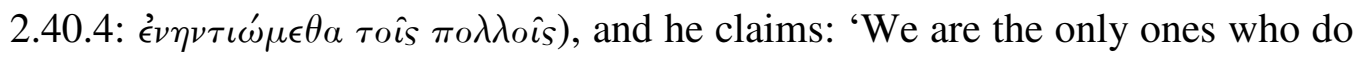
someone a favour without first calculating what we'll get out of it' (Thuc. $2.40 .5) .^{363}$

These speeches were a tool of propaganda used by the state in order to appropriate death from the aristocrats. The state funeral was held at a set time, and a single speech was performed on behalf of all the deceased. The state

\footnotetext{
${ }^{361}$ Walters (1980) 2.

${ }^{362}$ For futher examples see: Hdt. 7.10; 9.27.5: Thuc. 1.73.4; Lysias 2.20; Dem. 60.10-11; Plato Menex. 240C; Laws 698B-699D; Isoc. 4.97; 7.75.

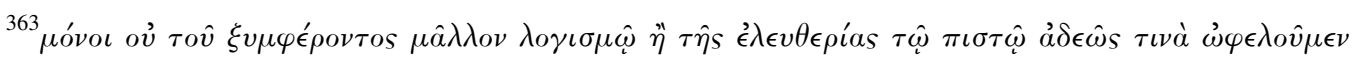
(trans. Walters (1980) 3).
} 
funeral limited the role that a family could play in the funeral of their kin. Removing family involvement contributed to a shift from a focus on family unity and the individual death to a public focus.

The secular prose of the funeral oration dedicates itself to celebrating the ideal of the democratic Athenian city. ${ }^{364}$ But within all these examples of Athenian supremacy is a glaring contradiction, one pointed out by Loraux. ${ }^{365}$ These speeches fought so strongly to put Athenian supremacy at the forefront that it seems completely contradictory that on the 'casualty lists' foreigners were inscribed alongside their Athenian counterparts. ${ }^{366}$ Foreigners who fought on behalf of Athens were given the same honours as the Athenian war dead.

\section{Conclusion}

The reason or reasons behind the change in burial practices in Athens are complex, with many social and political forces at work. It is implausible that a single factor, such as the Persian War or Oath of Plataea, caused the decline in funerary monuments. It is also doubtful that legislation was the single catalyst for such a decline. The population of Athens remained relatively stable, perhaps with a slight increase. The Cannonian model of expressive redundancy is not a suitable explanation for the change in Athenian burial practices: there was no significant reduction of wealth, and the aristocrats chose to redirect their dispensable income, as is shown by the use of votives. The development of

\footnotetext{
${ }^{364}$ Loraux (1993) 45.

${ }^{365}$ Loraux (1986) $36-37$.

366 Ibid, 32. Non-Athenians were included in these Athenian lists. The toxotai barbaroi, mentioned in four lists. (IG I² 950; Agora, XVII, nos. 14, 17, and 22.); Morris (1992) 132.
} 
state burial and the growing democracy are the keys. These developments led to a shift of focus from the individual to the collective. Death and cults of the dead, such as the Genesia, were appropriated by the polis and resulted in glorified state burials. Combined with the epitaphios logos the state funeral aided the development of democracy in Athens. The role of the family, and particularly that of the women was curtailed by the state funeral and focus shifted to the communal ideal. 


\section{The Re-emergence of the Grave Monument.}

The archaeological record reveals a reappearance of stone funerary sculpture in Athens a decade or so after the middle of the fifth century (c. 450-425 B.C.E.). ${ }^{367}$ In Athens there was no relaxation or repeal of funeral legislation during the course of the fifth century B.C.E. which is attested in our surviving sources. Therefore some other factor or factors must have been at work in order to re-establish the archaic practice, albeit with yet another ideological shift: from public to private. Multiple reasons have been suggested: Stears suggested the laws were simply 'relaxed' and no longer enforced. ${ }^{368}$ Whitley argues that Pericles' Citizenship law could help explain the re-emergence of grave markers and in particular the increased depictions of women. ${ }^{369}$ Robert Stupperich argues that the plague was a catalyst for the move back to proper funeral rites. ${ }^{370}$ Ferrario speculates that at sometime during the 430s B.C.E. relief funerary monuments reappear and that the reappearance could be co-incidental with or due to the outbreak of the Peloponnesian War. ${ }^{371}$ Boardman and Kurtz hypothesise that there was an influx of workers into Athens who worked on Pericles' building project, including the Parthenon, and when the project was complete the workers turned their hands to making grave markers. ${ }^{372}$ This chapter will examine a number of possible causes for the change and conclude that the most salient reason was the influence of foreigners. I will argue that

\footnotetext{
${ }^{367}$ Leader (1997) 101.

${ }^{368}$ Stears (2000) 49.

${ }^{369}$ Whitley (2001) 370.

${ }^{370}$ Stupperich (1977).

${ }^{371}$ Ferrario (2006) 88.

372 Boardman and Kurtz (1971) 122.
} 
foreigners brought with them their own burial practices and craftsmanship to Athens and that the setting up of grave markers by foreigners was the catalyst for Athenian aristocrats to reappropriate death from the state, resulting in another shift in focus from the polis back to the oikos.

\section{When Grave Markers Reappear}

First it is necessary to establish when funerary monuments reappeared. Various dates have been given: Stears argues for a gradual re-emergence between c. 450-425 B.C.E., ${ }^{373}$ stating that during these 25 years a mixture of diminutive plain stelae, mainly for citizens, and slightly more elaborate small stelae for foreigners, were being set up in small numbers in cemeteries and that at the same time an even smaller section of society was spending more money and purchasing stelae produced by metic sculptors who were working to their own traditions. ${ }^{374}$ Morris argues the latest date of around 425 B.C.E. ${ }^{375}$ Wendy Closterman, Meyer, Boardman and Kurtz, Lapatin, Roselli, and Humphreys all suggest a date of c. 430 B.C.E. for the re-emergence of the grave monument, in the form of figured reliefs, naiskoi ${ }^{376}$ and stone vessels in the shape of leykthoi and loutrophoroi. ${ }^{377}$ It seems most likely, given the broad consensus of

${ }^{373}$ Stears (2000) 49; if one accepts this dating then the plague cannot have been responsible for bringing back gravestones.

${ }^{374}$ Stears (2000) 51.

${ }^{375}$ Morris (1992) 148.

${ }^{376}$ A naiskos is a tall stele commonly flanked by high relief or free-standing statues of the dead housed within porches resembling temple-facades. Garland (1982) 129; Clairmont (1970) 62 63.

377 Lapatin (2007) 146; Meyer (1993) 107; Boardman and Kurtz (1971) 223; Humphreys 1980; Roselli (2006) 137; Closterman (2007) 634; The practice of erecting giant marble lekythoi inside periboloi lasted approximately from the last quarter of the fifth century to the end of the fourth century B.C.E. Normally their height varies from between $1 \mathrm{~m}$ and $1-2 \mathrm{~m}$, though there are a few 1-5 m tall. Garland (1928) 129. 
scholarly opinion, that grave markers, reminiscent of their Archaic predecessors, reappeared around 430 B.C.E.

\section{Nature of the Change}

\section{Change in Iconography}

When relief funerary stelae re-emerged they resembled the archaic shape and manner of composition: a slender slab, with or without a palmette. However, they were inferior in quality to their archaic counterparts and unsigned, unlike the monuments of the Archaic period. The iconography had also changed: women were more frequently depicted, and heroising markers now borrowed their symbols from state iconography rather than Homeric imagery as was the earlier practice. Humphreys states that 'the atmosphere of the [classical] reliefs is private and non-heroic' and that the dead are now depicted 'very often as a member of a united family group' and that 'the achievements and virtues commemorated in epitaphs are now, in the great majority of cases, those of family life'. ${ }^{378}$ However, there were still heroic stelae, although these were in the minority, and they too display a move towards a family focus. In the case of Dexileos his marker was set up by his family to celebrate his glorious death, but also to reflect the glory of the family (Appendix 2: Fig. 16). ${ }^{379}$ There is a notable shift from a group focus to an individual and family focus. Also present is an overall sense of a shift to commemorating individuals rather than

\footnotetext{
${ }^{378}$ Humphreys 1980; For grave-reliefs after 430 B.C.E. lacking a signature see Johansen (1951) 109 n. 10 .

${ }^{379}$ Dexileos will be discussed later in this chapter as a case study of the re-appropriation of death by Athenian aristocrats but it should be noted here that technically his monument is a cenotaph. Dexileos died in battle and was buried in a polyandrion in the Demosion Sema. His name is known from an inscription. His family chose to erect a monument in the private area of the Kerameikos, so for the purpose of this study I view Dexileos' monument as an example of a private grave marker as this seems to have been its purpose.
} 
commemorating universal qualities embodied by these individuals. ${ }^{380}$ The monuments often seem to depict individuals as they might have been in life, or as they might want to be portrayed as having been in life, and rarely depict the funeral itself or any aspect of the funeral (as terracotta plaques and fifth-century lekythoi could). ${ }^{381}$ After 430 B.C.E., therefore, individuals and monuments both became more independent - individuals from the web of aristocratic values, monuments from their implied relationship to the funeral. ${ }^{382}$ The emphasis had shifted from asserting a claim that the deceased led a glorious life, exemplary among the elite, to expressing the loss of a member of a household, of a friend or comrade. Bergemann has convincingly demonstrated how classical Athenian funerary iconography was not focused on the dead but displayed the ideal roles of the family in the context of the civic world of the polis. ${ }^{383}$ The family was shifting focus back to the individual within the oikos by showing their dead as idealised within the civic context, demonstrating that the individual and oikoi were central to the polis. As we shift from predominantly single figures to predominantly groups, the display of competitive virtues is replaced by the assertion of collaborative virtues. ${ }^{384}$ The oikos and the role of the deceased within the oikos became the primary focus.

Archaic tombstones focused on the adult male in his prime, whereas classical tombstones depict women, children, and the elderly, as well as men; in the

\footnotetext{
${ }^{380}$ Meyer (1993) 107 challenges the extent to which family depiction should be considered the defining quality of late fifth- and fourth-century commemoration in Athens.

${ }^{381}$ Ibid.

382 Ibid.

${ }^{383}$ Bergemann 1997 cited in Closterman (2007) 635.

${ }^{384}$ Osborne (1998b) 39.
} 
fourth century B.C.E., in place of isolated figures, groups commonly appear, which stress strong familial bonds. ${ }^{385}$ Perhaps the clearest expression of connection in classical funerary iconography can be found in the commonly represented dexiosis, or handshake. ${ }^{386}$ With the re-emergence of Classical grave markers a new ideology was on display. Family unity was again becoming the focus. $^{387}$ Athenian families were again erecting private monuments to commemorate their dead on a grand scale, in an attempt to subvert the growing democracy, but also to redefine what it was to be Athenian.

Masculinity continued to be a particularly acute political issue into the Classical period. The elite overtones of the image of man promoted by archaic sculpture, and particularly by archaic Attic funerary monuments, were undesirable to a city keen to declare its autochthonous citizens equal, and reluctant to accept attempts to define what it was to be a man in terms of activities, in particular the activities of the gymnasium, which were not effectively open to all. ${ }^{388}$ Osborne suggests that both the private display of classical tombstones, and the public sculpture of the Athenian Parthenon, negotiate a new image of masculinity which emphasises collaborative and community virtues rather than competitive and individual virtues. ${ }^{389}$ That new image of masculinity, however, continued to have to compete and co-exist with other images: the monument to the young

385 Closterman (2007) 634; For the focus on the young adult male in archaic funerary iconography, see Johansen (1951) 108 - 11; Day (1989) 20 - 2; Shapiro (1991) 632 - 33.

386 On the dexiosis as a symbol of unity, see, e.g., Johansen (1951) 149-51; Schmaltz (1983) $214-15$, suggests that it can express citizen associations as well as familial connections. Stears (1995) 126, argues that it may also convey the concept of equality; Ferrario (2006) 89: monuments with three or four adults on them display a dexiosis, a handshake of funerary farewell between two individuals, one of whom, according to Ferrario, is inevitably a warrior.

\footnotetext{
${ }^{387}$ Closterman (2007) 635.

${ }^{388}$ Osborne (1998b) $40-41$.

${ }^{389}$ Ibid.
} 
cavalryman Dexileos flamboyantly and obtrusively displayed individual virtue as it attempted to reclaim manhood as capital for a clan which, because of its collaboration with the oligarchic regime of the Thirty, had fallen under deep suspicion of not living up to the values of democratic man. ${ }^{390}$ Even within the democratic city, politics continued to be played out on the male body. ${ }^{391}$

\section{Reasons For The Change}

\section{Prices for Burial Markers}

Could the price of burial markers have come down to a price that more people could afford? In the literary sources the purpose of stating the costs was invariably to emphasise how expensive the burial was. When a grave marker does have the cost stated it is likely to be an exceptional case and therefore not representative of the average cost, so it is no surprise that law court speeches list much higher prices than the epigraphical evidence. Lysias in 490 B.C.E claims that 2,500 drachmae were spent on a tomb (32. 21); Demosthenes c. 358 B.C.E. records a sum of 1,000 drachmae was spent on a funeral, a high percentage of which would have been on the tomb (40.52). Demosthenes in 359 B.C.E. claims a sum of over two talents was spent on a tomb (45.79). This claim is suspect in that it was in Apollodorus' interest to arouse prejudice against Phormion by exaggerating. All of Conon's bank balance was used to defray his funeral expenses ([Dem.] 48.12). ${ }^{392}$ These claims in the law courts display a trend of growing expense in respect to funerals and funeral monuments, however such large numbers are countered by the epigraphical sources.

\footnotetext{
${ }^{390}$ Ibid, 41.

391 Ibid.

${ }^{392}$ Davies (1971) xix n.3.
} 
The only epigraphical source cited by Davies gives the lowest price of 30 drachmae for two burials: ${ }^{393}$

Isarchos son of Philon of Xypete argued that 30 drachmai were due him on the house in Alopeke which Theomnestos son of Deisitheos of Ionidai registered "for I buried Theophilos, whose house this was, and the wife of Theophilos "; it was decided that (the money) was due." 394

The stones which could have been used as grave markers could have been bought for just a few obols, as inscriptions attest: 'setting up of these stones: a drachma, two and a half obols ${ }^{395}$ : "each stone: a drachma, two and a half obols': ${ }^{396}$ 'each stone 5 obols'. ${ }^{397}$ Neilsen et al argue that the majority of grave markers were of the inexpensive kind; this being the case we should expect to find many simple stones with simple inscriptions, however these are lacking from the archaeological record: ${ }^{398}$ against 76 naiskoi and 356 other decorated monuments decorated with reliefs, there have been excavated 588 undecorated stelae and 71 kioniskoi. $^{399}$

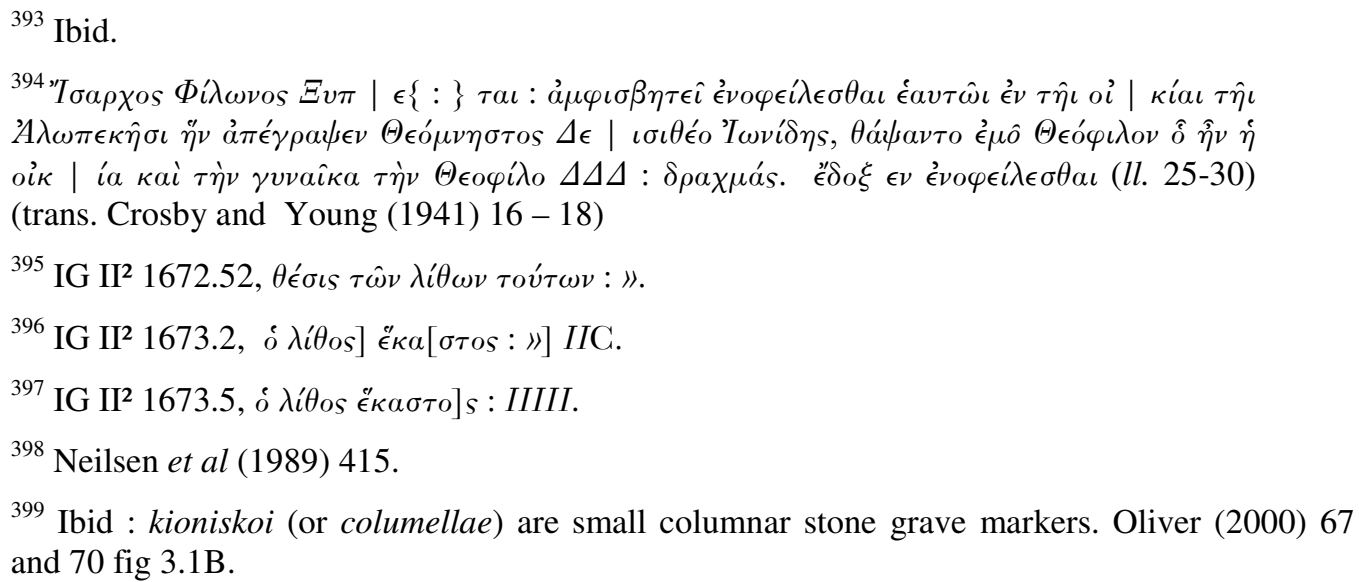


The prevailing orthodoxy seems to be that the corpus of sepulchral inscriptions reflects the demography of the upper class only. ${ }^{400}$ Most recently Osborne, David Whitehead, and Garland have restated the orthodoxy. ${ }^{401}$ However a prosopographical study of the citizens commemorated in sepulchral inscriptions indicates that there is no clear connection between the wealth of citizens and the splendour of their gravestones. ${ }^{402}$ Both Gomme and Damsgaard-Madsen accept without discussing the problem that during this period tombstones with sepulchral inscriptions were erected by Athenian citizens irrespective of their wealth and social status. ${ }^{403}$ Neilsen et al question this orthodoxy and suggest that even poor citizens could have easily afforded a grave monument inscribed with their name. They put the total cost of a simple grave monument with a short sepulchral inscription at less than 20 drachmae and suggest that it was probably not much more than ten drachmae, if decorated with a small standard relief. $^{404}$ Roselli claims that a single stele with a modest relief would likely have cost between thirty and fifty drachmae, ${ }^{405}$ and that Athenian citizens (and residents of Attica) could also have chosen a less expensive painted monument without any relief. ${ }^{406}$

A direct economic explanation for funerary displays, that more extensive commemoration is simply a consequence of more extensive resources, is

\footnotetext{
${ }^{400}$ The high cost of funerary monuments is stressed by Morris (1992) $135-138$ and Oliver (2000).

${ }^{401}$ Osborne (1985) 130; Whitehead (1986) 354; Garland (1987) 66; Neilsen et al (1989) 412.

${ }^{402}$ Neilsen et al (1989) 415.

${ }^{403}$ Gomme (1933) 44f and Damsgaard (1988) 55 - 68 cited in Neilsen et al (1989) 412.

${ }^{404}$ Neilsen et al (1989) 414.

${ }^{405}$ Roselli (2006) $141-142$.

${ }^{406}$ Posamentir (2001) 63 cited in Roselli (2006) 142.
} 
unlikely. For 'although private wealth may have survived even as the fourthcentury Athenian state scrounged for revenue, it is implausible - given that the economic picture is so unclear (and apparently bleak) - that economic factors alone could have encouraged the Athenians,' between 430 and 330 B.C.E., to adopt a new and more expensive form of commemoration. ${ }^{407}$

\title{
Plague
}

Other scholars stress the plague that hit Athens in $430 .{ }^{408}$ Stears argues that the various pressures of the plague combined with the Peloponnesian War may have spurred on the fashion for the fine sculpted monuments amongst the pious. ${ }^{409}$ However Thucydides notes that in the fifth century the plague created fewer, not more, commemorated burials:

\begin{abstract}
And the custom which they had hitherto observed regarding burials were all thrown into confusion, and they buried their dead each one as he could. And many resorted to shameless modes of burial because so many members of their households had already died that they lacked the proper funeral materials. Resorting to other people's pyres, some, anticipating those who had raised them, would put on their own dead and kindle the fire; others would throw the body they were carrying upon one which was already burning and go away. (Thuc. 2.52.4) ${ }^{410}$
\end{abstract}

\footnotetext{
${ }^{407}$ Meyer (1993) 105; Nielsen et al. (1989) 411 - 420 argue stones were inexpensive; Davies. (1971) xix n.3 argues they were relatively expensive; For the role of wealth in burials, see Morris. (1992a) $103-27$.

${ }^{408}$ Stupperich (1977); Fuchs (1961) 241 - 2 cited in Humphreys (1993) $104-5$.

${ }^{409}$ Stears (2000) 51.

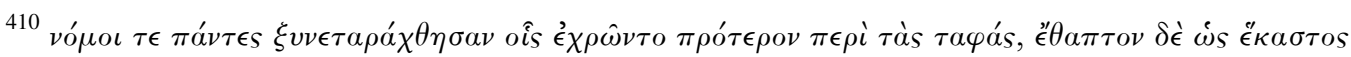

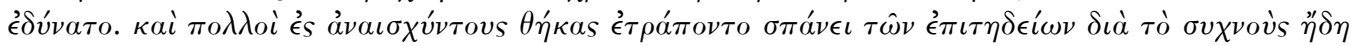

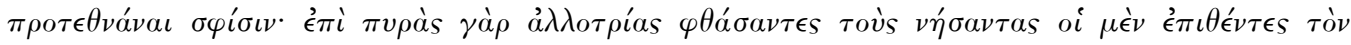

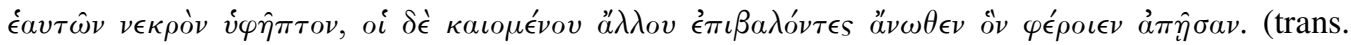
Smith)
} 
Clairmont prevaricates and overstates the case: 'while it is essential to keep in mind the external causes - the war and the plague - that led to the rebirth of classical gravestones, the sculpture of the Parthenon, in the very broadest sense, is the preliminary per se for the creation of grave reliefs. ${ }^{411}$ Morris states that it might be possible to argue for a casual link between the behaviour described by Thucydides (2.52.4) and the subsequent increase in funeral spending; but this remains to be demonstrated. ${ }^{412}$ Stears, who argues for an earlier date for the establishment of Classical funerary monuments, rules out the plague as a factor because, if her hypothesised date of c.450 B.C.E is correct, the plague had not yet hit Athens. ${ }^{413}$ Humphreys argues that the representation of elaborate tomb markers on vases shows that the wish to set up such monuments existed well before the plague, even if the practice was rare. ${ }^{414}$ The plague may have reminded Athenians of the importance of proper funeral rites, but it seems unlikely that a single event, such as the plague, was the catalyst for the return to large and grand funeral monuments.

\section{The Role of the Law}

The ancient sources provide no evidence that the Solonian funeral laws or the post aliquanto law were repealed nor is there any evidence for any other legislation which again allowed for grand funerary monuments. There is little evidence of how these laws were enforced during the period of restraint or even

\footnotetext{
${ }^{411}$ Clairmont (1970) 43.

${ }^{412}$ Morris (1994) 72.

${ }^{413}$ Stears (2000) 49.

${ }^{414}$ Humphreys (1993) 105.
} 
that they were responsible for the period of anti-display; Stears argues that they must have been enforced, either by tacit, socially enforced agreement, or more explicitly by nomophylakes (guardians of the law), ${ }^{415}$ but there is no evidence to corroborate these claims. $^{416}$ Perhaps after a generation (30 years) the law become gradually disregarded. ${ }^{417}$ It is apparent from the archaeology that foreigners seem to have been exempt - at least partially - from the laws or prevailing democratic ideology, which curtailed Athenian monuments, as was noted in Chapter One. ${ }^{418}$ The role of foreigners will be further discussed later in this chapter.

\section{Pericles' Citizenship law}

There is no evidence of more funeral laws until the reforms of Demetrius of Phaleron (317 B.C.E.); but there is evidence of Pericles' citizenship law which may have had an indirect effect on funerary monuments, both in number and iconography. The citizenship law prescribed that both parents, not only the father, had to be citizens in order to have their children accepted as citizens. ${ }^{419}$ There are few ancient testimonia for Pericles' citizenship law. The Athenian Constitution records in a brief entry that in the archonship of Antidotos, on account of the large number of citizens, and on proposal from Pericles, the Athenians decided that anyone not born from citizen parents would not have a

\footnotetext{
${ }^{415}$ Lape (2004) 48.

${ }^{416}$ Stears (2000) 47.

417 Ibid.

${ }^{418}$ See pp. $34-35$.

${ }^{419}$ Examples of Athenian men marrying foreign women in the years after 480 B.C.E are lacking, but marriage to foreigners was at no point made illegal. Osborne (1997b) 7.
} 
share in the city (Ath. Pol. 26.4). ${ }^{420}$ Plutarch in his Life of Pericles records further information about the citizenship law (37.2-5) (Appendix 1: 7). Plutarch recounts previously when Pericles had been in power and had his own legitimate sons he had passed a law that only those born from two Athenians were citizens. Now back in power, and no longer with legitimate heirs, he sought the pity of the demos and asked for his previous law to be relaxed so that his family and name would not be bereft of a successor. The demos, thinking he had suffered enough, agreed to enrol his illegitimate son among the phraters giving him Pericles' name (Plutarch, Pericles 37.3-5). ${ }^{421}$

The motivation for the citizenship law is not clear. Aristotle attributes the law to the large number of citizens (Ath. Pol. 26.4). ${ }^{422}$ Gomme supports Aristotle's reasoning, stating that 'the chief motive was a fear lest the population would continue increasing and eventually make the constitution unworkable. ${ }^{, 423}$ This view has been countered by modern scholarship: Osborne argues that population growth is an inadequate explanation of Pericles' citizenship law. ${ }^{424}$ Another popular argument is that Pericles' law was provoked by a concern for racial purity, a stance most strongly supported by Hignett. ${ }^{425}$ Humphreys argues that the citizenship law was intended to stop Athenian aristocrats

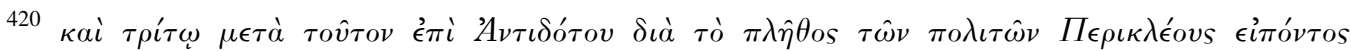

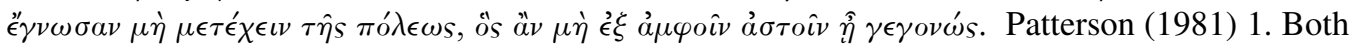
Aelian Hist. Misc. 6.10 and the Suda, s.v. demopoietos have entries about Pericles' citizenship law, and both seem to follow the Plutarchian tradition. For further discussion see Patterson (1981) $1-2$.

${ }^{421}$ Patterson (1981) 2.

${ }^{422} \delta \iota \grave{\alpha} \tau \grave{o ̀} \pi \lambda \hat{\eta} \theta 0 s \tau \hat{\omega} \nu \pi o \lambda \iota \tau \hat{\omega} \nu$.

${ }^{423}$ Gomme (1933) 87. cf. Patterson (1981) $100-102$.

${ }^{424}$ Osborne (1997b) 5 does not believe the Aristolelian explanation because he argues it is unlikely that Aristotle had an accurate knowledge of Athenian demographic history.

${ }^{425}$ Hignett (1951) 346. Also Bowra (1971) 93. cf. Patterson (1981) 97 - 98. 
marrying outside of Athens and forming powerful alliances with other poleis through marriage. ${ }^{426}$ Patterson argues that there was a possible connection between the increasing value of Athenian citizenship and the citizenship law. ${ }^{427}$ She then goes on to argue that the increase in population in Athens between 480-450 B.C.E. was the result of the inclusion of non-Athenians into Athenian tribes. ${ }^{428}$ Extrapolating her argument further, perhaps the law was a reaction to an influx of foreign workers who were bringing with them their own traditions.

Whatever the motivation for the citizenship law, it resulted in the status of the mother becoming as important as the status of the father, ${ }^{429}$ in the sense that women were recognised as necessary in order to pass citizenship onto their sons. ${ }^{430}$ Beyond this limited recognition of women's status, it must be emphasised that although male power must flow through women, they act as mere conduits for citizenship, never having a share of that male power themselves. ${ }^{431}$ However, women possessed further limited recognition in that they were utilised on grave monuments to show the solidarity of the oikos. A monument was a permanent and visible marker of one's lineage and would have been useful especially at the meeting of the deme-assembly at which a youth's status was determined, as put by Whitley: 'What better way to affirm one's own (or one's children's) status as a good citizen than to put up a stele for your wife

\footnotetext{
${ }^{426}$ Humphreys (1974) 93. cf. Patterson (1981) 101.

${ }^{427}$ Patterson (1981) 103.

${ }^{428}$ Ibid.

${ }^{429}$ Stears (2000) 52, the mother had to be of citizen status, i.e. the daughter of an Athenian citizen.

${ }^{430}$ Roy (1999) 5.

${ }^{431}$ See Rubin (1975) especially $191-2$ for women as perennial objects of exchange rather than exchangers.
} 
or mother?' which could then be used to demonstrate lineage and one's wellborn status. ${ }^{432}$ A man had to meet three criteria in order to be a citizen: he had to be eighteen, free (not a slave), and born in accordance with the laws (Ath. Pol. 42.1). This means, after the enactment of Pericles' citizenship law in 451/0 and its re-enactment in 403/2, that a youth had to be born of two citizen parents in order to qualify as a citizen himself.

Thus as a consequence of the citizenship law and as Humphreys argues and I argued above, there is more emphasis on family in fourth-century B.C.E. monuments and epitaphs, and more examples of family burial-plots and groupings. ${ }^{433}$ This emphasis existed not only for its own sake but to reinforce the assertions of citizenship, of belonging, that many individuals wished to make. ${ }^{434}$ Closterman and Stears argue that the citizenship law, because it placed more emphasis on the role of the mother, might have served not only to encourage the reintroduction of the permanent tomb marker itself, but especially to promote a new fashion: the regular commemoration of women. ${ }^{435}$

\section{The Role of the Thirty}

The definition of citizenship was not only important in the fourth century, but had become so at the end of the fifth century in Piraeus and Athens. The

\footnotetext{
${ }^{432}$ Whitley (2001) 370.

433 Humphreys (1993) 103; Multiple fifth-century burials in the same grave, although interpretation of this as family, without epigraphic evidence, is problematic; $111-117$. 17 sets of inscriptions found together that belong to people probably related to each other.

${ }^{434}$ Meyer (1993) 112.

${ }^{435}$ Closterman (2007) 649; Stears (2000) 52; Roy (1999) 5 also tends to the belief that Pericles' citizenship law was a contributing factor to women becoming more frequently depicted on funerary monuments.
} 
activities of the Thirty also drew attention to the links between citizenship, burial, and commemoration. Lysias (12. 21, cf. 12. 96) said that:

For they sent many of the citizens into exile with the enemy; they unjustly put many of them to death, and then deprived them of burial; many who had full civic rights they excluded from the citizenship; and the daughters of many they debarred from in tended marriage. $^{436}$

It was dangerous even to conduct funerals (12. 88). Lysias was appealing to his audience's belief that citizens had a right not to be treated this way, and that citizens had a right to be buried. Interfering with the recently dead was rare in Athens, and generally limited to tragedy or legend; it took men like the Thirty to make this horror a reality. ${ }^{437}$

Disruption of life, freedom, citizenship rights and definitions, and burial all characterised the reign of the Thirty. After their fall, there were major changes to efface their memory. Even the physical layout of the Kerameikos changed. To the south, the construction of the massive 'Terrassenanlage' for private tombs had begun as early as the 420 s, but changes accelerated after 400 ; to the north, the road to the Academy was widened; and horos-markers for the entire area were set up. ${ }^{438}$ The most prominent new features of the north side of the

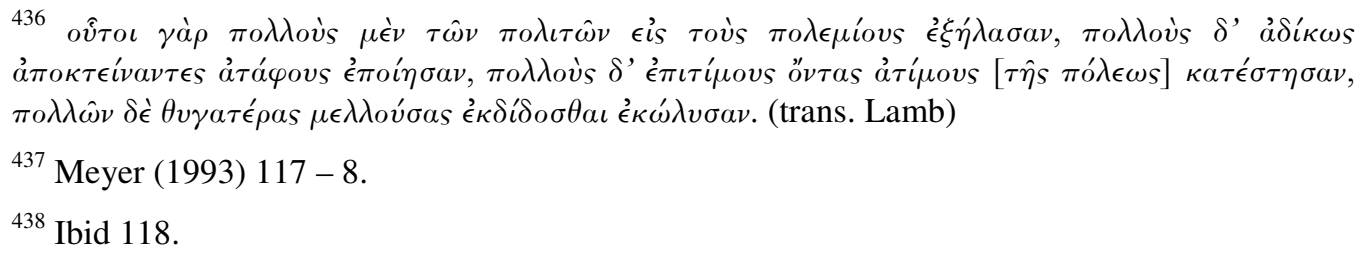

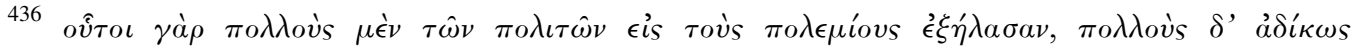

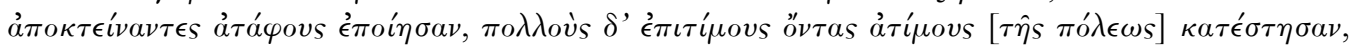

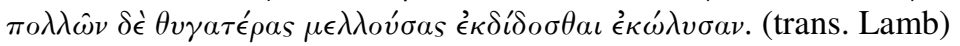

${ }^{437}$ Meyer (1993) $117-8$.

${ }^{438}$ Ibid 118. 
Kerameikos were the polyandrion of the Spartans who died fighting in 403 B.C.E., perhaps a polyandrion of the Piraeus democrats, and the tomb of their leader Thrasybulus, which attracted Pausanias's attention in the second century C.E. (1. 29.3). ${ }^{439}$ The usual explanation for the prominent Spartan tomb is either that the burial was carried out when the Thirty tyrants were still in power, or that it was a commitment of the Thirty to their Spartan allies that the democrats, in the spirit of reconciliation, honoured. ${ }^{440}$

\section{City Wall}

In 431 B.C.E., the Athenians moved themselves behind the protection of the city's walls, in from the Attic countryside where most of them had been accustomed to live, the apparently traumatic effects of which Thucydides reports:

Because of their long-continued life of independence in the country districts, most of the Athenians of early times and of their descendants down to the time of this war, from force of habit, even after their political union with the city, continued to reside, with their households, in the country where they had been born; and so they did not find it easy to move away, especially since they had only recently finished restoring their establishments after the Persian War. They were dejected and aggrieved at having to leave their homes and the temples which had always been theirs, - relics, inherited from their fathers, of their original form of government and at the prospect of changing their mode of life, and facing what was nothing less for each of them than forsaking his own town. (Thuc. 2.16). ${ }^{441}$

\footnotetext{
${ }^{439}$ Ibid.

${ }^{440}$ Patterson (2006b) 32.

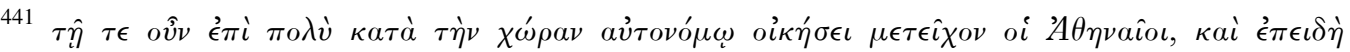


Being truly Athenian thus received physical reinforcement, but also thereby acquired some new and fearsome aspects, especially when plague followed. Uprooted and irrevocably committed to being inhabitants of a beleaguered city, Athenians started to consider seriously the nature of their politeia and their own role in it. Meanwhile, many perished in the war. ${ }^{442}$ Relatives or friends of some of the dead could claim the privilege of burial in the Kerameikos, a desire Aristophanes was mocking, by 414 B.C.E., in his play, the Birds.

In the Birds Peisthetairos introduces himself and his sidekick, Euelpides, to the audience as citizens among citizens, who nonetheless were fleeing Athens, 'the opposite of Sakas, a non-citizen trying to force his way in!' (32-33) ${ }^{443}$ Despite this flight Peisthetairos reassures Euelpides that if they fall prey to menacing talons and beaks, 'the Kerameikos will welcome us. In order to be buried publicly, we'll tell the generals that we died fighting at Orneae!' (395-6) Peisthetairos "is smoothly confident that the claim of a minor skirmish - and a bad joke - will win them a public burial. ${ }^{445}$ Athens' agreed-upon prize for service was a state burial, and commemoration in the Demosion Sema, and such

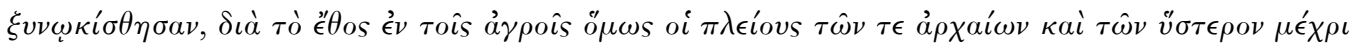

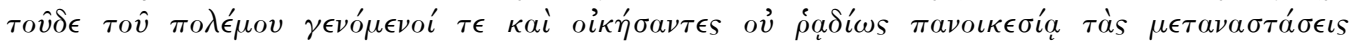

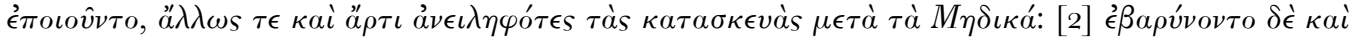

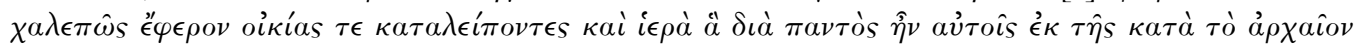

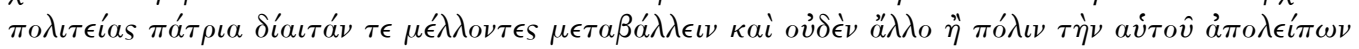

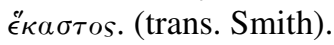

${ }^{442}$ Hansen (988) 22.

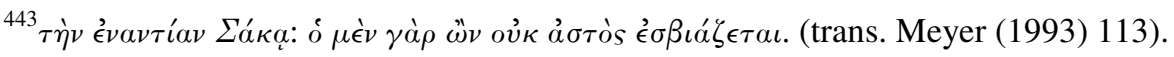

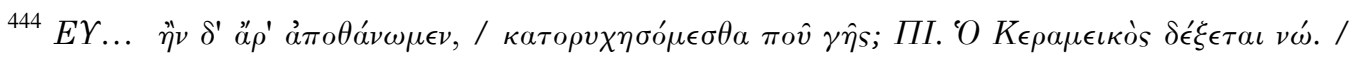

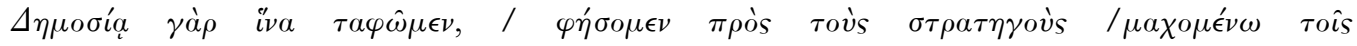

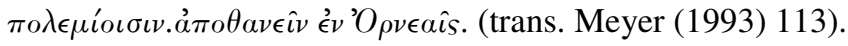

${ }^{445}$ Meyer (1993) 113. 
'an honour was sufficiently valued, and sufficiently bestowed, to be parodied. $^{, 446}$

\section{Peribolos Tombs}

In Classical Athens, as part of a desire to show familial relationships, it seems a greater tendency came about to bury family members together, within periboloi: large rectangular spaces walled on the front and at the sides, to which access could be gained only from the rear. ${ }^{447}$ Family plots became popular by the end of the fifth century B.C.E., and contained grave monuments commemorating all the family dead, including household slaves. ${ }^{448}$ Periboloi became more and more elaborate from the late fifth century onwards. Eventually, some contained the remains of four generations of one particular clan. ${ }^{49}$ This shift to family may explain why funeral monuments began to become increasingly more lavish.

A peribolos of a large size is attested only in literary sources. ${ }^{450}$ The speaker of [Dem] 43 takes great pains to present himself as a member of an oikos of faultless solidarity and piety towards the dead and claims that the descendants of Bouselos, his great grandfather, shared a common burial ground ([Dem] 43.79). ${ }^{451}$ The information provided by [Dem] 43 and in Isaeus 11 suggests the burial place may have held 22 members of the family. ${ }^{452}$ However both archaeological and epigraphic evidence suggest that groups of this size were

\footnotetext{
${ }^{446}$ Ibid : Contra Loraux who finds this passage 'ambiguous'; see Loraux (1986) 20, 309 - 310 for further discussion.

${ }^{447}$ Garland (1982) 128.

${ }^{448}$ Garland (1998) $119-20$.

${ }^{449}$ Whitley (2001) 369.

${ }^{450}$ Humphreys (1993) 110.

${ }^{451}$ Ibid.

${ }^{452}$ Ibid.
} 
unusual. Many periboloi enclosed only two or three graves, or at the most half a dozen. $^{453}$ The fourth century mound of Eukoline in the Kerameikos held only four or five. ${ }^{454}$ Inscriptions tell the same story. ${ }^{455}$

The Peribolos tomb primarily served as a way for Athenian citizens to easily identify their familial linage and assert their citizenship status. However, Closterman argues against this notion, concluding that:

In the context of peribolos tombs, classical Attic funerary monuments had a stronger ideological than documentary function. Their primary role was to present a family portrait, rather than to serve as a repository for information about burial or a family's genealogical history. Instead of providing a complete record of those buried in the tomb, an easily navigable portrayal of the individuals commemorated, or the intricacies of the family tree, the facade of a peribolos tomb conveyed an image of family solidarity as measured against the backdrop of the Athenian ideal. By selectively choosing details from their burial history and familial relations to emphasize in their tomb facades, families portrayed themselves with the traits of a successful Athenian familylongevity, virtue, and intergenerational harmony. ${ }^{456}$

The peribolos echoed the structure of the oikos, or the structure that an oikos wanted to present. The kin groups constructed their memory, history and credentials. The interplay among funerary markers in family tombs suggests that

\footnotetext{
${ }^{453}$ Ibid, 111 .

${ }^{454}$ Schlorb-Vierneisel (1966) 77 - 8 cited in Humphreys (1993) 111.

455 See Humphreys (1993) 111 - 113 for a full breakdown of inscriptions and familial relationships.

${ }^{456}$ Closterman (2007) 651.
} 
commemoration did not aim to identify clearly all commemorated individuals or trace the complete details of a family tree; rather, the tomb façade prioritized family connections more generally. In the centre, the tall narrow anthemion or shaft stele lists the principal members of the family; of those that survive, women are at the head of only one-fifth of them, ${ }^{457}$ and, Stears suggests, feature only if they bring land as a dowry or have an unusual degree of influence. ${ }^{458}$ However there are two further possible reasons for locating one's dead within a fixed space: firstly with the state establishing the Genesia (see my earlier discussion) the family was limited to one day a year on which to visit and celebrate the dead, therefore in order to mourn all the dead it is logical to bury them with each other. ${ }^{459}$ Secondly there seems to have been a belief that the family would be able to reunite in the hereafter if its members were buried in the same place: this belief is reflected in the group depictions and the dexiosis representation, where one figure greets another. ${ }^{460}$

Two examples, which demonstrate this family trend and which were set up within periboloi, are: the stelae of Hegeso (Appendix 2: Fig. 10) and Ampharete (Appendix 2: Fig. 12). The Hegeso stele, dating to c. 400 B.C.E., depicts a certain Hegeso, the daughter of Proxenos. ${ }^{461}$ She is shown in profile, framed by a pediment with antae, and seated on a high-backed chair. She appears to be examining a box of jewellery being presented to her by her maid. ${ }^{462}$ Hegeso's

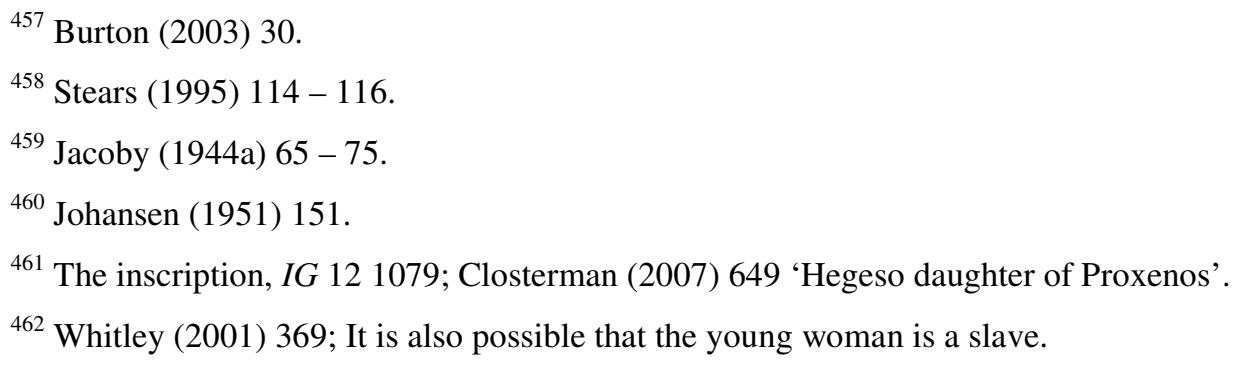


age and circumstance are unclear, as the inscription contains little detail. In the sculpture she appears young, and somewhat generic. Closterman describes her as an 'idealized Athenian woman' shown as the quintessential Athenian wife, seated indoors and gazing down at an object. ${ }^{463}$ Apart from her hairpiece there is little that distinguishes her from any other wife or mother, an idealisation she is not intended to resemble any particular individual, but more of a type. Hegeso (Appendix 2: Fig. 10) resembles Ampharete (Appendix 2: Fig. 12) a woman depicted on another gravestone, and also an image of a seated woman from an earlier white-ground lekythos by the Achilles Painter. ${ }^{464}$

An example of the dexiosis and familial composition is seen in the Stele of Damsistrate, c. 400 B.C.E. (Appendix 2: Fig. 16) The dexiosis gesture signifies equality, emphasising that such images are better read as a mediation between male and female spheres than as a confrontation between polis and family. Both male and female are here shown as part of the family, indicating that death has failed to separate them. ${ }^{465}$ The gesture itself is one that belongs also to the public sphere. In the fourth century, in place of isolated figures, groups commonly appear, which stress strong familial bonds. Multifigured funerary stelae, common particularly in the fourth century B.C.E., frequently depict multiple generations together in the same scene, whether father and son, parents and children, or grandparents and grandchildren. ${ }^{466}$

\footnotetext{
${ }^{463}$ Closterman (2007) 648.

${ }^{464}$ Whitley (2001) 368; For more about Ampharete see Clairmont (1993) $404-408$.

465 Johansen (1951) 151.

${ }^{466}$ Closterman (2007) 648; Bergemann (1997) 87 - 8, 92 - 3, shows that multiple generations appear together more frequently than married couples.
} 
The collection of funerary markers in a peribolos tomb, when taken together, paints a picture of a successful family that has escaped the kind of challenges that appear in the rhetoric of the Attic orators, such as the extinction of the family line, generational conflict, and improprieties in the behavior of women. $^{467}$ Funerary markers in classical Attic family tombs express a generalized family ideology more than a specific family history in response to an increasing perception in late fifth and fourth century B.C.E. Athens that families were threatened. ${ }^{468}$ Grouping burials in this way no doubt led to interclan rivalry and partially explains the increasing grandeur of funeral monuments.

\section{Epitaphs}

The relationship between representation and writing in the surviving Athenian monuments changed dramatically between the sixth and fourth centuries B.C.E. Writing more than art was clearly becoming the vehicle chosen to convey a message about the deceased. ${ }^{469}$ Torben Vestergaard has noted that from Attica alone, Athens being the most active epigraphic city in the Greek world, there are well over 12,000 published private sepulchral inscriptions dating between the seventh century B.C.E. and third century C.E. ${ }^{470}$ In Conze's collection of 2,225 grave-reliefs from the fifth century B.C.E. through the Roman period, 1368 $(61.5 \%)$ have writing associated with them, and of the 10,263 epitaphs studied

\footnotetext{
${ }^{467}$ Closterman (2007) 633.

468 Ibid.

${ }^{469}$ Conze (1893 - 1922) cited in Meyer (1993) 108.

${ }^{470}$ Vestergaard (2000) 81, n.2. Very few people are recorded in inscriptions dating from the Archaic period and from the third century C.E. and on.
} 
by Conze only $1,869(18.2 \%)$ are associated with relief. ${ }^{471}$ Even epigrams become longer and longer over time. ${ }^{472}$ The fifth and fourth centuries are already well advanced in this trend, with $54.2 \%(970 / 1,789)$ of Conze's reliefs inscribed, and only $37.4 \%(1,182 / 3,163)$ of Conze's epitaphs (of all types) associated with reliefs. An interesting point made by Sourvinou-Inwood is that the language used of women in epitaphs is often very similar to that used of men. ${ }^{473}$ Women may be described as 'excellent', 'wise', 'good'; or a combination of these. They may also possess those highly valued qualities (for both sexes) of 'self-control', 'temperance', and 'goodness'; they, like men, may be 'pious'. ${ }^{474}$ However perhaps of more note for this study is that it is possible to identify within this collection both Athenians and non-Athenians: counting persons inscribed in the nominative case (leaving out fathers and husbands in the genitive case), Vestergaard has registered around 3,300 foreigners with ethnics. $^{475}$ Of these less than two percent date from the fifth century, about 15 per cent from the fourth century, nearly 40 per cent from the post-classical period including the first century B.C.E. and roughly 35 per cent from the Roman. ${ }^{476}$ This epigraphical evidence indicates that there was an increase in the number of foreigners who were having private sepulchral monuments erected and inscribed in Athens. A notable increase from two per cent in the fifth

\footnotetext{
${ }^{471}$ Conze (1893 - 1922) cited in Meyer (1993) 108.

472 Taken from Meyer (1993) 108, see n. 20 for sources of numbers.

${ }^{473}$ Sourvinou-Inwood (1995) 117 - 118.

${ }^{474}$ Burton (2003) 26.

475 Vestergaard (2000) 81 - 82 n.3. The corresponding number of Athenian citizens with demotics is roughly 4,000. The numbers of persons inscribed without demotics or ethnics is even higher (called 'homines originis incertae' in $I G$, a group which may include citizens as well as foreigners, isoteleis, and slaves.)

${ }^{476}$ Ibid, 82. About eight per cent of the persons with ethnics are inscribed on stones that have been left undated.
} 
century to 15 per cent in the fourth century ties in with the increase in grandeur of Athenian funeral moments.

It is unlikely that the large number of fourth-century epitaphs can be explained by a higher death rate or a larger Athenian population, for there is no reason to suppose the former, and Hansen, as noted above, has shown that in the fourth century 'the number of Athenians living in [Athens and] Attica must have been almost stationary and sometimes even declining' due to slow natural growth combined with the emigration of citizens. ${ }^{477}$ He estimates a decline from a high of perhaps 60,000 in the mid-fifth century to a minimum of 25,000 by the end of that century, with a 'recovery' to 30,000 or so by 330 B.C.E. ${ }^{478}$ Even the most extreme counter-suggestion of 2 per cent growth per year in the fourth century, which results in doubled population by 349 B.C., cannot explain an eight-fold increase in epitaphs. ${ }^{479}$ The funerary monuments are unlikely to reflect the relative sizes of the actual foreign population in Attica. It possible that some foreigners came to Attica for a limited time and then returned to whence they came therefore left less impact in the epigraphic record than their numbers would otherwise have indicated. ${ }^{480}$

\section{The Parthenon and Pericles' Building Project and Sculpture}

Many workers were recruited into Athens to work on Pericles' building projects, ${ }^{481}$ and this has led some to argue that the increase in monuments was a

\footnotetext{
${ }^{477}$ Hansen (1933) cited in Osborne (1997b) 5.

478 Ibid.

${ }^{479}$ Meyer (1993) 105; Note that in the fifth century B.C.E. the plague created fewer, not more, commemorated burials (Thuc. 2. 52.4).

${ }^{480}$ Gauthier (1972) 124. n.55. cited in Vestergaard (2000) 89.

${ }^{481}$ Boardman and Kurtz (1971) 122; Johansen (1951) 146.
} 
result of the influx of sculptors into Athens in the 440s B.C.E. Diepolder, Roselli, Boardman, Kurtz, and Whitley argue that the fashion of funeral sculpture partially re-emerged because there were many sculptors in need of employment. $^{482}$ Johansen goes as far as to say 'it can hardly be mere coincidence that during the building of the Parthenon grave stelae in Attica once again flourish. ${ }^{483}$ By 430 B.C.E., when the Peloponnesian War got under way and the money for statues dried up, presumably some of the sculptors turned to producing gravestones; stimulated by this supply, the Athenians began to demand such markers. However, Morris highlights what he views as a logical problem: most of the post-425 B.C.E. funerary monuments are not sculptural. ${ }^{484}$ It hardly requires talent of the kind that produced the Parthenon frieze to make dressed stone blocks for a Peribolos tomb ${ }^{485}$ but there would have been a number of sculptors who had to turn their talents to the production of grave markers. Parthenonian stylistic traits are evident in the new series of grave reliefs but so too is the influence of foreign hands. ${ }^{486}$

The earliest sculpted memorials, as Schmaltz has emphasised, show clear influence of Cycladic funerary stelae, not only in sculpted style, but also in iconography, and must be dated to the decades immediately prior to 430

${ }^{482}$ Diepolder (1931) cited in Roselli (2006) 138; Whitley (2001) 369; Boardman and Kurtz (1971) 122; Roselli (2006) 138, sees the influx of workers as part of the reason for the increase in sculptued monuments, but not the main enabling reason because he does not see that an influx of workers can explain the change in funerary iconography.

\footnotetext{
483 Johansen (1951) 146.

${ }^{484}$ Morris (1994) 72.

485 Ibid.

${ }^{486}$ Lapatin (2007) 146.
} 
B.C.E. ${ }^{487}$ The influx of foreign artisans with their own commemorative traditions may not have served only as the stylistic influence for the first sculpted gravestones but as one of the factors in the very erection of grave monuments following c.450 B.C.E. Their ignorance of, possible exemption from, even their disdain for, the restrictions of the post aliquanto legislation may have hastened its breakdown. ${ }^{488}$

Continuity is shown between sculptors from other Greek regions and those in Attica. The figure on the Giustiniani stele originally from Paros (Appendix 2: Fig 14) is repeated on another, somewhat later, imperfectly preserved Attic stele; and another Attic fragment found at Daphni just outside Athens, with the remains of a cloaked man, is closely associated with the Karystos stele. ${ }^{489}$ It should be noted, however, that from the new start in Athens sculptors did not limit themselves to the single-figure reliefs which might be said to continue the old Attic line, but that they depicted compositions of groups with no stylistic ancestors in Attica. ${ }^{490}$

\section{Foreigners}

The study of foreigners commemorated on tombstones in Attica reveals at least two remarkable and highly interesting features: first, the strong numerical predominance of only three groups of foreigners; second, sex distribution which shows a very high proportion of women. The largest single group are the

\footnotetext{
${ }^{487}$ Schmaltz (1983) 200 cited in Stears (2000) 50.

488 Stears (2000) 50; See Chapter One which demonstrates that non-Athenians were exempt from the laws which restricted Athenian funerary monuments.

${ }^{489}$ Johansen (1951) 147 and $124-126$ also see Fig. 60 on 125.

${ }^{490}$ Johansen (1951) 147.
} 
Milesians (24.5 per cent of all foreigners), followed by the Heracleots (11 per cent) and Antiochenes (8.3 per cent). ${ }^{491}$ The Milesians are the most numerous foreigners from about 100 B.C.E to the second century C.E. The Heracleots predominate from the fourth to the second century B.C.E. The number of Antiochenes reached a peak in the first century B.C.E. and first century C.E. ${ }^{492}$

The second observation to be made about the appearance of foreigners on the tombstones found in Attica concerns sex distribution. Of the total number of foreigners 51.8 per cent are men, and 45.8 per cent are women; it has not been possible to state the sex of the remaining 2.4 per cent owing to lacunas in the text. ${ }^{493}$ In the earlier centuries the number of women is smaller: in the fifth century B.C.E. females only constitute 14 per cent of attested persons, in the fourth century B.C.E. 34.7 per cent, and in the third century B.C.E. 39.8 per cent. $^{494}$

At the time when funeral markers begin to re-emerge in Athens there is evidence of an increase of foreigners coming into Athens, such as those sculptors who worked on the Parthenon. These foreigners may have relocated their families to Athens, and when family members died would have had to bury and commemorate their dead. Epigraphy bears witness to an increase in numbers of foreigners in Athens. Burial was not considered an exclusive

\footnotetext{
${ }^{491}$ Ibid, 86. 793 Milesians, 355 Heracleots and 269 Antiochenes.

492 Ibid. The Heracleots, because they are seldom encountered in the Roman period, Vestergaard argues, most likely came from only one of the main cities named Heraclea, in this case Heraclea Pontica on the Black Sea coast of Asia Minor.

${ }^{493}$ Ibid, 88. Proportionately more women's names appear on gravestones in the Hellenistic and Roman periods: constantly around 50 per cent.

${ }^{494}$ Ibid.
} 
privilege for Athenian citizens. Indeed in the historical survey of patriotic death in his 'Funeral Oration' (Lysias 2), Lysias asserts that:

It is right that we should also praise the strangers who lie here: they came to the support of the people, and fought for our salvation; they regarded valour as their native land, and with this noble end they closed their lives. In return the city has not only mourned them but given them a public funeral, and has granted them in perpetuity the same honours as it gives to its own people. (Lysias 2.66) ${ }^{495}$

Archaeological evidence also reveals that foreigners were willingly buried in Athens. Pythagoras of Selymbria, a proxenos, who seems to have died around 450 B.C.E., was commemorated with a marble stele set up over an inscription on a limestone plinth (Appendix 2: Fig. 15). ${ }^{496}$ This stele was a public monument erected just outside the Dipylon gate. ${ }^{497}$ The inscription reads 'the Athenians placed here at public expense Pythagoras son of Dionysios. And with his death, grief came to his horse-grazing fatherland, Salymbria., ${ }^{498}$ This stele is telling; Whitley argues that plainness was the keynote of the early fifth

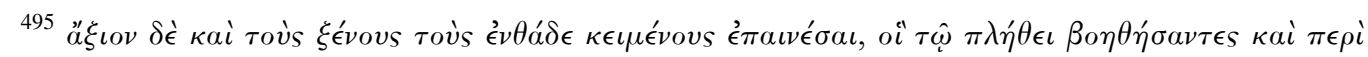

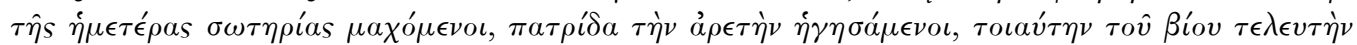

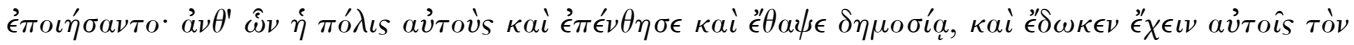

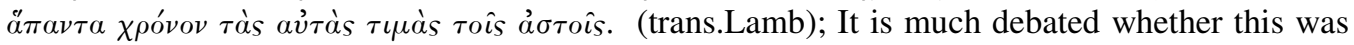
an actual epitaphios logos. Some argue that it was an epitaphios logos that was delivered by someone else and tradition has ascribed it the wrong author. Others argue it was an exercise by Lysias to demonstrate his rhetorical skill. See Todd (2000) $25-27$ (the introduction to his translation of Lysias 2)

496 Clairmont (1983) 61; Whitley (2001) 366, rather subjectively terms the monument as 'nothing grander than a marble stele'.

497 Johansen (1951) 122, interestingly Johansen writing 50 years earlier than Whitley (n. 495) describes the same stele as 'an unusually fine and impressive' representative monument. It is interesting that in the space of 50 years opinion of the same stele has changed dramatically, thus emphasising just how subjective the interpretation of art can be.

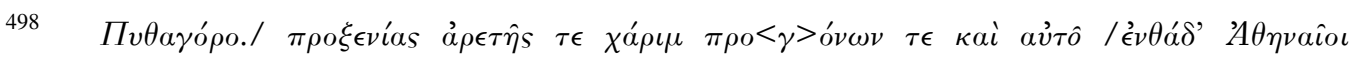

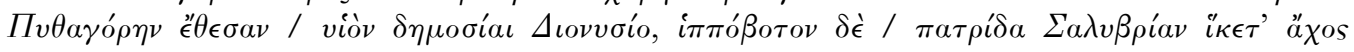
$\varphi \theta \iota \epsilon^{\prime} v o . \quad\left(I G^{3} 1154\right)$ (trans. Patterson (2006b) 22.) 
century B.C.E. and that the 'plain style' even extended to the tombs of distinguished foreigners. ${ }^{499}$ However this tomb, erected at public expense, was probably more lavish than the markers the majority of Athenians got, bar the war dead. Its quality and location demonstrate that Athenians were accepting of the burial of foreigners in their city.

Morris argues that what happened in Athens, the re-emergence of grand burials in the 420s B.C.E., ${ }^{500}$ was but one part of a much wider geographical trend. ${ }^{501}$ Morris is constantly at pains to place the Athenian phenomena of the reemergence of grand funeral monuments in a Panhellenic context but does not mention the roles of foreigners within Athens, who seem to have been able to bury their kin ostentatiously, even whilst Athenians were still adhering to restraint. ${ }^{502}$ As Patterson puts it 'Morris is very aware of the existence of nonAthenian tombs and burials in Attica. He [Morris] duly acknowledges that many non-Athenians did receive formal burial in Athens - but explains that "like any ideology, Athenian funerary discourse was complex and contradictory.",503 Patterson critiques Morris' argument appropriately as it appears he has left out a large section of evidence, a section which could have a considerable effect upon ideology, namely foreigners bringing their own burial practices with them.

\footnotetext{
${ }^{499}$ Whitley (2001) 366.

500420 s B.C.E. is the date Morris argues for the re-emergence of grand funerary monuments. As outlined earlier I contend that the reemergence occurred a decade or so earlier, in the $430 \mathrm{~s}$ B.C.E.

${ }^{501}$ Morris (1994) 73.

502 Patterson (2006a) $51-2$.

503 Ibid.
} 
The tombstones of the fourth and third centuries found in Athens and Piraeus (I.G. II I682ff) show that there is scarcely a deme, however small and remote, that is not represented among the tomb stones found. ${ }^{504}$

We hear of various imported cults in fifth- and fourth-century Athens. This demonstrates that foreigners, or at the least foreign beliefs, were being imported and perhaps accepted in Athens. ${ }^{505}$ In an inscription of 333/2B.C.E., an association of import traders from the Phoenician city of Kition in Cyprus is granted land on which to build a temple for its own cult of Aphrodite (i.e. Astarte); the inscription notes a precedent, in the form of an Egyptian temple to Isis. ${ }^{506}$ A festival of the Thracian goddess Bendis was introduced at Athens early enough to be mentioned in Plato's Republic. ${ }^{507}$

\section{Foreign Women}

It is already well documented that whilst Athenian citizens were no longer buried in a grand fashion, foreigners were and the number of foreign stele increases at the same time as women become much more frequently depicted on grave markers. Gravestones belonging to metic women frequently employ the same iconography as those of Athenian women and exhibit the same range in quality. ${ }^{508}$ Osborne explains the similarity of such monuments to those of Athenian women by reference to 'the pressures on the metic community to

${ }^{504}$ Gomme (1986) 44 - 45 provides a breakdown (in chart form) of tombstones found in Athens and Piraeus with demes inscribed on them.

505 Todd (1996) 44.

${ }^{506}$ Simms (1997/8) 125 n.23 and n.24.

507 Todd (1996) 44.

${ }^{508}$ Clairmont (1993) CAT, V.9-10; see CAT2.2S7 for an example showing the deceased Arnion and his seated mother Demokrita, from Corinth. 
conform to local practice'; in addition, he points out that the iconographical similarities between Athenian monuments and those of the metics' home cities would make such conformity unproblematic. ${ }^{509}$ However, if women's grave monuments assert the citizen status of the women, as Osborne argues, in response to Pericles' law, one might have expected some distinction to be made between the two groups in terms of their iconography - especially as metic women are the very group that the law was designed to exclude. ${ }^{510}$ Their presence, sharing the same public space as their Athenian counterparts, would seem to imply that there was an impetus towards the depiction of women of both groups. As Diana Burton points out, that metic women shared the same iconography as citizens is good evidence against Pericles' citizenship law being the impetus behind women being more frequently depicted. ${ }^{511}$ Osborne argues that metics were being forced to conform to Athenian ideals; however I contend that it was the foreigners who influenced Athenian grave monuments. ${ }^{512}$ When Athenian familles saw foreigners setting up grave markers they in turn wanted to erect their own monuments. This could explain why both groups, metics and Athenian citizens, have markers of equal quality.

Epigraphical habits were significantly different for foreign women than Athenian women. Until the third century B.C.E at least, foreign women were registered as metics. ${ }^{513}$ It is significant that the foreign/metic women generally had their ethnics in the nominative feminine (as e.g. Milesia, Antiochissa),

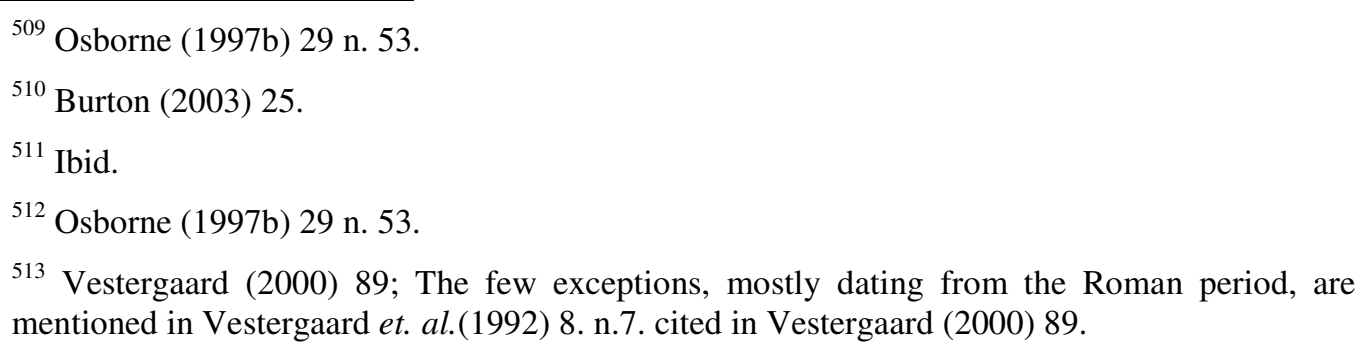
mentioned in Vestergaard et. al.(1992) 8. n.7. cited in Vestergaard (2000) 89. 
contrary to citizen women, who almost always carried demotics in the genitive masculine, i.e. the demotics of their fathers and husbands. ${ }^{514}$ It is highly plausible that foreign women enjoyed a freedom of movement which their Athenian counterparts did not. The notorious female metic Neiaira, a former prostitute, was described as an 'independent' woman who was her own guardian. ${ }^{515}$ Demosthenes claims that decent women would be outraged by the thought that Neiaira participated in public ritual ([Dem] 59.110ff.). ${ }^{516}$ This independence is closely tied to social status. Women, when given excessive license, were thought to invariably engage in wanton and/or lascivious behaviour; note the affair of Euphiletos' wife in Lysias 1, which took place when Euphiletos slackened his control over his wife. ${ }^{517}$ An Athenian citizen woman would be subject to close surveillance by male kin, because bloodlines, legitimacy and citizenship were considered crucial in Classical Athens, especially with Pericles' citizenship law having focussed the public gaze on the legitimacy of citizens. It is possible that foreign women were allowed more licence because their behaviour would not threaten the legitimacy of Athenian citizens. $^{518}$

\footnotetext{
${ }^{514}$ Ibid.

${ }^{515}$ Ibid; [Dem] 59.46 .

${ }^{516}$ Stears (1998) 123.

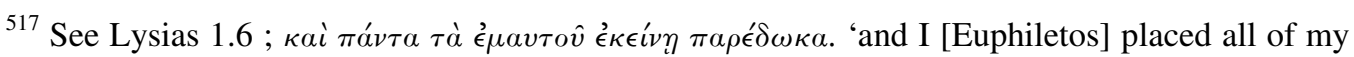
affairs in her hands'.

${ }^{518}$ Closterman (2007) 648; Lysias 1.33 shows how seriously adultery was taken in Classical Athens, as it was seen as a threat to the blood line.
} 


\section{Re-appropriation by Aristocrats}

Between 396-350 B.C.E. prominent Athenian citizens appear more often in the honorific epigraphical record, enjoying elevated status and public acclaim alongside xenoi: 'they are officially recognised and memorialised in a highly visible manner, one that cultivates, and perhaps even reifies, the public perception of their importance. ${ }^{519}$ We can trace this process of the Athenian elite 'muscling in' on collective symbolism at least as far back as the 410s, when a burial at Chalandri north of Athens has an inscription proclaiming the man's personal contribution to Athens' military prowess (IG II 7716) and a relief sculpture strikingly like Dexileos. ${ }^{520}$

The best example, and therefore case study, of the appropriation of state iconography is the Dexileos monument (Appendix 2: Fig. 16). ${ }^{521}$ It was part of a complete remodelling of this area of the Kerameikos for private grave precincts, which may have started as early as the 420 s B.C.E. ${ }^{522}$ In 394 B.C.E. Dexileos was killed in the Corinthian War. He was buried in the polyandrion for that year, but within sight of it his family put up a cenotaph topped by a superb relief sculpture. ${ }^{523}$ The family marker was a high relief representing Dexileos on horseback defeating a fallen enemy. It faced the direction of the Demosion Sema and was set some four metres back from the street corner and five metres above ground level. There was no access to the monument, thus the monument

\footnotetext{
${ }^{519}$ Ferrario (2006) 96.

${ }^{520}$ Clairmont (1983) $67-8$; Morris (1992) 144.

${ }^{521}$ For a fuller study of Dexileos and his monument see Hurwit (2007a) 35 - 60.

${ }^{522}$ Morris (1992) 41. Again Morris argues 420s B.C.E, to tie in with his dating the re-emergence of grave monuments to the 420s B.C.E.

523 Ibid, 40; The inscription (IG II 5222; cf. 6217, and see Clairmont (1983) 209 - 214) preserves his name; See n. 378 for discussion of the monument as a cenotaph.
} 
was physically but poignantly distanced from the viewer. ${ }^{524}$ Interestingly Dexileos' inscription gives a date of birth, which is unique to Greek epitaphs. ${ }^{525}$ This date of birth emphasises his youth, but also, and perhaps most crucially, indicates he was too young to have had anything to do with the antidemocratic actions of the Athenian cavalry ten years earlier. ${ }^{526}$ It is unlikely that Dexileos was an eccentric outlier - as noted above there are other similar but fragmentary finds similar to that of Dexileos - but more that his family was seeking to differentiate itself from the demos. Dexileos represents a dichotomy: on the one hand his date of birth is used to prove he was not part of an antidemocratic movement, but yet state symbols have been appropriated to differentiate him in death. Scenes of fighting on private monuments were probably borrowed from the iconography of state burials. ${ }^{527}$

\section{Conclusion}

Foreigners coming into Athens, perhaps to work on Pericles' building project, turned their hands to making grave markers and imparting their own burial customs. These grave markers shared similarities with their Archaic counterparts but now presented a different image. State symbols were appropriated by the aristocrats and applied to their own markers, such as the case of Dexileos; women were more frequently depicted and were placed in a

\footnotetext{
${ }^{524}$ Hurwit (2007a) 38.

${ }^{525}$ Ibid, 39; of 10,000 epitaphs no others mention a date of birth.

${ }^{526}$ Dexileos' inscription reads: Dexileos, son of Lysanias, of Thorikos I He was born in the arconship of Teisandros [414/3 B.C.E.]; I He died in that of Euboulides [394/3 B.C.E.], I at Corinth, one of five horsemen. (trans. Hurtwit (2007) 38), see Appendix 2: Fig 17 for the Greek of the inscription.

527 Stupperich (1994) 95; Morris (1992) 143, the iconography of Dexileos' monument is very similar to that of a relief of the early 420s B.C.E. now in the Villa Albani, which probably comes from a war grave.
} 
domestic setting, such as Hegeso; and now the dead are presented, as they would have been in life and commemorated for their historical importance. Periboloi became more common and were used by wealthy families to demonstrate familial unity. This change in ideology was a combination of many factors, but as has been shown in this chapter, the influx of foreigners into Athens who brought with them their own burial practices was the catalyst for Athenian aristocrats to erect grand monuments and to again return focus to their burials. 


\section{$\underline{\text { Conclusion }}$}

It is apparent, as Chapter One demonstrated, that a change in burial practices occurred in Athens between 510 and 480 B.C.E. The archaeological record shows clear differences: lavish grave markers, kouroi, korai, and stelae begin to dwindle in numbers between 510 and 480 B.C.E and then disappear for 50 years. When monuments re-emerged there is evidence of an ideological change: no longer is the grave marker the domain of an idealised man reminiscent of the Homeric hero; women and the domestic sphere become more commonly depicted; and where men were individually celebrated they now used state symbols to define themselves rather than Homeric allusions. Literature too shows a change in burial practice and ideology: that laws were thought necessary shows a growing concern surrounding death and the possible effects of miasma. That miasma was a growing concern is indicated by the increased push towards extramural burial. The most important change in funeral behaviour was the creation of the state burials in the Demosion Sema. Funerals went from being private aristocratic affairs used by wealthy families to win the favour of the demos, to more regulated occasions utilised by the state to create a collective ideology.

The motivations behind the change in burial practices are complex, with many social and political forces at work. As argued in Chapter Two, it is unlikely that a single factor, such as the Persian War or plague caused the decline in funerary monuments. It is doubtful that legislation was the catalyst for decline, as it seems unlikely that Solon was codifying what was happening, but rather 
instigated change in order to try and calm civil unrest. The development of State burial and growing democracy are the keys. These developments led to a shift of focus from the individual to the collective. Death was appropriated by the polis resulting in glorified state burials which, together with the epitaphios logos, aided the development of democracy in Athens. In Homer's epics, the monumental tomb helped to create deathless glory for the individual hero; in fifth century Athens this was turned on its head, with oikoi abstaining from elaborate markers, while the polis used the tomb to create a collective ideal.

In Chapter Three the re-emergence of the grave marker was discussed. These grave markers shared similarities with their Archaic counterparts but now presented a different image. I argued that state symbols were appropriated by the aristocrats and applied to their own markers, such as the case of Dexileos; that women were more frequently depicted and were placed in a domestic setting, such as Hegeso; and that the dead were now presented as they would have been in life and commemorated for their historical importance. This change in ideology was a combination of many factors, but as has been shown, one of the most salient causes was the influx of workers to Athens who brought with them their own burial practices, in turn inspiring Athenian aristocrats to erect grand monuments and to once again return focus to their private, family oriented burials.

No single factor caused the disappearance and re-emergence of grand funeral markers. But what is clear is that burial markers were used, by both the oikos and polis, as tools to advance status. The first change was brought about 
because of a struggle between the growing democracy and the established aristocracy, where both sides were trying to win the favour of the demos. The second change was brought about by the aristocracy trying to re-establish its own identity. Foreigners either ignored or were exempt from the laws pertaining to funerals and were allowed by the democratic polis to set up their own monuments, which increased in both number and size from the turn of the Classical period.

It is clear some form of ideological change was occurring. The key linking factor responsible for the change, I contend, was the struggle over what it meant to be an Athenian citizen. The polis was central, but the polis could not escape the fact that it relied on the oikoi to produce the citizens to form the polis, hence Pericles' citizenship law which sought to define what was required in order to be a citizen. The state appropriated death as a way to focus attention on the polis, and to create a collective ethos to aid the growth of democracy. However under this democracy foreigners seem to have held a special place: they were allowed to have slightly more lavish grave markers (which increased in numbers as the century progressed) and were included on the Athenian casualty lists. As a reaction to this, perhaps Athenian citizens felt that foreigners were using the cemetery (as the Athenian citizen had done in previous centuries) to advertise their own status, thereby subverting what it meant to be an Athenian citizen. Therefore Athenian citizens, utilising foreigners and their burial customs, started to erect their own monuments to their dead, thus reasserting their own status. This surge in monuments for foreigners incited the aristocrats to disregard the democratic ideology they had been constrained by for 50 years 
and to again use funerary monuments to publicly celebrate their dead and win the favour of the demos. The monuments of the Classical period grew in lavishness until 317 B.C.E. when Demetrius of Phaleron deemed it necessary to legislate against such ostentatious funeral behaviour. 
Bibliography

(includes works consulted but not directly cited)

\section{Primary Resources}

Aelian, Historical Miscellany (trans and ed. N.G. Wilson) Cambridge, 1997.

Aeschines, Aeschines (trans. C. Carey) Austin, TX. 2000.

Aeschylus, Agamemnon (trans. R. Lattimore). Oxford, 1953.

_L Libation Bearers (trans. R. Lattimore). Oxford, 1953.

_ Persians (trans. E. Hall). Warminster, 1996.

Aristophanes, Birds, Lysistrata Women at the Thesmophoria (trans. J. Henderson) London and Cambridge, Ma. 2000.

—Clouds, Wasps, Peace (trans. J. Henderson). Cambridge, 1998.

_Lysistrata (trans. S. Halliwell). Oxford, 1998.

Aristotle, The Athenian Constitution (trans. H. Rackham) London, 1971.

Cicero, De Legibus (trans. C.W. Keyes). London, 1928.

Cicero, Letters to Friends (trans. D.R. Shackleton Bailey) London, 2001. vol. 2.

Demosthenes, Selected Private Speeches (trans. C. Carey and R.A. Reid) Cambridge, 1985.

Diodorus Siculus, Diodorus of Sicily (trans. C.H. Oldfather) Cambrige, MA. 1946 - 1967. 12 vols.

Dionysios of Halicarnarssus, The Critical Essays (trans. S. Usher) Cambridge, Ma. 1974 - 1985. 2 vols.

Euripides, Trojan Women (trans. D. Kovacs). Cambridge, MA. 1999.

_ Alcestis (trans. C. R. Beye). Englewood Cliffs, NJ. 1974.

_ Suppliants (trans. K. McLeish). London, 1997.

Herodotus, Histories (trans. A. Godley) London, 1921.

Hesiod, The Homeric Hymns; and, Homerica (trans. H. G. Evelyn-White) London, 1936. 
Homer, Iliad (trans. A.T. Murray, revised by W.F. Wyatt) London, 1925 (reprinted 2001) 2 vols.

_Iliad (trans. R. Lattimore). Chicago, IL. 1961

Odyssey (trans. W.Merry, J. Riddell and D.B. Monro). New York, NY. 1987. 2 vols.

Hypereides, The Forensic Speeches (trans. D. Whitehead). Oxford, 2000.

Inscriptiones Graecae http://epigraphy.packhum.org/inscriptions/main

Isaeus, Isaeus (trans. E. S. Forster). London, 1927.

Isocrates, Isocrates I (trans. D. Mirhady \& Y. Lee Too.). Austin, TX. 2000.

__ Isocrates II (trans. T. L. Papillon). Austin, TX. 2004.

Lysias, Lysias (trans. W.R.M. Lamb) London, 1967.

_ Orations (trans. S.C. Todd) Austin, TX. 2000.

Pausanias, Guide to Greece (trans. P. Levi). Baltimore, MD. 1971. 2 vols.

Pindar, Pindar (trans. W.H. Race) Cambridge, MA. 1997. vol. 1.

_ Pindar: Victory Odes (ed. M.M. Willcock) Cambridge, 1995.

Plato, Plato (trans. R.G.Bury). London, 1961. 7 vols

Plutarch, The Rise and Fall of Athens: Nine Greek Lives (trans. I. Scott-Kilvert). New York, NY. 1987.

_ Plutarch's Moralia (trans. F.C. Babbitt) Cambridge, MA. 1927. 15 vols.

_L Lives (trans. B. Perrin) London, 1916. 3 vols.

Terence, Terence (J. Barsby) Cambridge, MA. 2001. vol. 2

Thucydides, History of the Peloponnesian War (trans. C.F. Smith) London, 1991.

— The Peloponnesian War (trans. S. Lattimore). Indianapolis, IN. 1998.

Xenophon, A History of My Times (trans. R. Warner). New York, NY. 1979. 


\section{Secondary Sources}

Albinus, L. (2000) The House of Hades: Studies in Ancient Greek Eschatology. Aarhus.

Alcock, S. (1991) 'Tomb Cult and the Post-Classical Polis.' American Journal of Archaeology. 95: 447-467.

Alexiou, M. (2002) The Ritual Lament in Greek Tradition. Lanham. (2nd ed. Revised by D. Yatromanolakis and P. Roilos).

Andrewes, A. (1998) 'The Growth of the Athenian State.' in The Expansion of the Greek World, Eighth to Sixth Centuries B.C., Cambridge Ancient History, (J. Boardman \& N.G.L. Hammond eds.) Cambridge. 3.3: 360 - 391. 2nd ed.

Angus, S. (1928) The Mystery-Religions: a Study in the Religious Background of Early Christianity. London.

Ariès, P. (1981) The Hour of Our Death. (trans. from French by H. Weaver) New York, NY.

Asheri, D. (1963) 'Laws of Inheritance, Distribution of Land and Political Constitutions in Ancient Greece.' Historia. 12: 1 - 21.

Barringer, J.M. (2008) Art, Myth, and Ritual in Classical Greece. Cambridge and New York, NY.

Bassett, S.E. (1938) Poetry of Homer. Berkley, CA.

Bennett, L.J. and Tyrell, W.B. (1990) 'Sophocles' Antigone and Funeral Oratory.' The American Journal of Philology. 111: 441 - 456.

Bekker, I.(1821) Anecdota Graeca. Berlin. vol. 1.

Blok, J. (2006) 'Solon's Funerary Laws: Questions of Authenticity and Function.' in Solon of Athens: New Historical and Philosophical Approaches. Leiden. 197 - 247.

Blok, J. and A. Lardinois (2006) Solon of Athens: New Historical and Philosophical Approaches. Leiden.

Boardman, J. (1978) Greek Sculpture: The Archaic Period: A Handbook. London.

- (1955) 'Painted Funerary Plaques and Some Remarks of Prothesis.' Annual of the British School at Athens. 50: 55 - 66.

Bosworth, A.B. (2000) 'The Historical Context of Thucydides' Funeral Oration.' The Journal of Hellenic Studies. 120: 1 - 16. 
Bowie, E.L. (1986) 'Early Greek Elegy, Symposium, and Public Festival.' Journal of Hellenic Studies. 106: 13 - 35.

Bowra, C.M. (1971) Periclean Athens. London. (1938) Early Greek Elegists. Oxford.

Bradeen, D.W. (1969) 'The Athenian Casualty Lists.' Classical Quarterly. 19: $145-59$.

Bremmer, J. (1983) The Early Greek Concept of the Soul. Princeton, NJ.

Brown, B. (2003) 'Homer, Funeral Contests and the Origins of the Greek City' in Sport and Festival in the Ancient Greek World. (D. Phillips and D. Pritchard eds.) Swansea. $123-162$.

Bruss, J.S. (2005) Hidden Presences: Monuments, Gravesites and Corpses in Greek Funerary Epigram. Leuven.

Burford, A. (1972) Craftsmen in Greek and Roman Society. London.

Burkert, W. (1985) Greek Religion: Archaic and Classical. Oxford.

Burton, D. (2003) 'Public Memorials, Private Virtues: Women on Classical Athenian Grave Monuments.' Mortality. 8: 20 - 35.

Buxton, R. (ed) (1999) From Myth to Reason? Studies in the Development of Greek Thought. Oxford.

Cannon, A. (1989) 'The Historical Dimension in Mortuary Expressions of Status and Sentiment.' Current Anthropology. 30: 437 - 458.

Camp, J.M. (2001) The Archaeology of Athens. London.

Carawan, E. (2008) 'Pericles the Younger and the Citizenship Law.' The Classical Journal. 103: 383 - 406.

Clairmont, C.W. (1993) Classical Attic Tombstones. Kilchberg. 6 vols.

_ (1986) 'Some Reflections on the Earliest Classical Attic Gravestones.' Boreas. 9: 27 - 50 .

- (1983) Patrios Nomos: Public Burial in Athens During the Fifth and Fourth Centuries B.C.: The Archaeological, Epigraphic-Literary, and Historical Evidence. Oxford.

(1970) Gravestone and Epigram: Greek Memorials from the Archaic and Classical Period. Mainz on Rhine. 
Closterman, W.E. (2007) 'Family Ideology and Family History: The Function of Funerary Markers in Classical Attic Peribolos Tombs.' American Journal of Archaeology. 111: $633-652$.

Connor, W.R. (1987) 'Festivals and Processions: Civic Ceremonial and Political Manipulation in Archaic Greece.' The Journal of Hellenic Studies. 107: 40 - 50.

Crosby, M and Young J. (1941) ‘Greek Inscriptions.’ Hesperia. 10: 14-30.

Day, J.W. (1989) 'Rituals in Stone: Early Greek Grave Epigrams and Monuments.' The Journal of Hellenic Studies. 109: 16 - 28.

Davies, J.K. (1993) Democracy and Classical Greece. Harvard, MA.

_ (1981) Wealth and the Power of Wealth in Classical Athens. New York, NY.

(1971) Athenian Propertied Families. Oxford.

Derderian K. (2001) Leaving Words to Remember: Greek Mourning and the Advent of Literacy. Leiden.

Donohue, A. (2005) Greek Sculpture and the Problem of Description. New York, NY.

Dyck, A. (2004) A Commentary of Cicero, De Legibus. Ann Arbor.

Eliot, C.W.J. (1962) Coastal Demes of Attika: A Study of the Policy of Kleisthenes. Toronto.

Ellis, J.R. and Stanton, G.R. (1968) 'Factional Conflict and Solon's Reforms.' Phoenix. 22: $95-110$.

Ferrario, S.B. (2006) 'Replaying Antigone: Changing Patterns of Public and Private Commemoration at Athens c. 440-350' Helios. 33s: $79-118$.

Fine, J.V.A. (1983) The Ancient Greeks: A Critical History. Cambridge, MA.

Finley, M. (1983) Politics in the Ancient World. Cambridge.

Foley, H. (2001) Female Acts in Greek Tragedy. Princeton, NJ.

Fornara, C. W. (ed. and trans.) (1983) Archaic Times to the End of the Peloponnesian War. Cambridge.

Foxhill, L. (1997) 'A View from the Top: Evaluating the Solonian Property Classes' in The Development of the Polis in Archaic Greece. (L.G. Mitchell and P.J. Rhodes eds.) London and New York, NJ. 113 - 136. 
Fraser, P.M. (1995) 'Citizens, Demesmen and Metics in Athens and Elsewhere.' in Sources for the Athenian Greek City-State (Acts of the Copenhagen Polis Centre vol. 2) (M. H. Hansen ed.) Copenhagen. $64-90$.

Freeman, K. (1976) The Work and Life of Solon: With a Translation of his Poems. New York, NJ.

Friedlander, P. and Hoffleit, H.B. (1948) Epigrammata. Berkeley, CA.

Frisone, F. (2000) Leggi e Regolamenti Funerari nel Mondo Greco: I. Le Fonti Epigraphiche. Lecce.

Gagarin, M. (2008) Writing Greek Law. Cambridge. (1986) Early Greek Law. Berkley, CA.

Garland, R. (2001) Greek Way of Death. (2nd ed.). New York, NY.

— (1998) Daily Life of the Ancient Greeks. Westport, CT.

_ (1989) 'The Well Ordered Corpse: An Investigation into the Motives behind Greek Legislation.' Bulletin of the Institute of Classical Studies. 36: 1 15 .

(1987) The Piraeus. London.

(1982a) 'A First Catalogue of Attic Peribolos Tombs.' Annual of the British School at Athens. 77: 125 - 76.

Garland, R. (1982b) 'Geras Thanonton: An Investigation into the Claims of the Homeric Dead.' Bulletin of the Institute of Classical Studies. 29: 69 - 80.

Garner, R. (1987) Law and Society in Classical Athens. London.

Garrison, E.P. (1991) 'Attitudes Towards Suicide in Ancient Greece.' Transactions of the American Philological Association. 121: 1 - 34.

Gomme, A.W. (1986) The Population of Athens in the Fifth and Fourth Centuries B.C. Oxford.

_ (1933) 'The Law of Citizenship at Athens.' in Essays in Greek History and Literature. Oxford. $67-88$.

Hägg, R. (1983) 'Burial Customs and Social Differentiation in $8^{\text {th }}$ - Century Argos' in The Greek Renaissance. (R. Hägg ed.) Stockholm. 27 - 31.

Hall, J.M. (2006) A History of the Archaic Greek World. Malden, MA.

Hame, K.J. (2008) 'Female Control of Funeral Rites in Greek Tragedy: Klytaimestra, Medea, and Antigone.' Classical Philology. 103: 1 - 15. 
_ (2004) 'All in the Family: Funeral Rites and the Health of the Oikos in Aischylos' Oresteia' American Journal of Philology. 125: 513 - 538.

Hansen, H. (1990) Aspects of the Athenian Law Code of 410/09 - 400/399 B.C. New York, NY.

Hansen, M.H. (1986) Demography and Democracy: The Number of Athenian Citizens in the Fourth Century B.C. Herning.

Harrison, A.R.W. (1968) The Laws of Athens. Oxford. vol. 1.

Harrison, E.B. (1956) 'Archaic Gravestones from the Athenian Agora.' Hesperia. 25: $25-65$.

Hedrick Jr., C.W. (1999) 'Democracy and the Athenian Epigraphical Habit.' Hesperia. 68: 387 - 439.

Hignett, C. (1952) A History of the Athenian Constitution to the End of the Fifth Century B.C. Oxford.

Hodkinson, S. (2000) Property and Wealth in Classical Sparta. London.

Hoffman, H. (1994) 'Dulce et Decorum est Pro Patria Mori: the Imagery of Heroic Immortality on Athenian Vases.' in Art and Text in Ancient Greek Culture (S. Goldhill and R. Osborne eds.) Cambridge. 28 - 51.

Hölkeskamp, K-J. (1999) Schiedsrichter, Gesetzgeber und Gesetzgebung im archaischen Griechenland. Tübingen.

(1992a) 'Written Law in Archaic Greece.' Proceedings of the Cambridge Philological Society. 38: 87 - 117.

(1992b) 'Arbitrators, Lawgivers and the 'Codification of Law' in Archaic Greece. Problems and Perspectives.' Metis. 7: $49-81$.

Holst-Warhaft, G. (1992) Dangerous Voices: Women's Lament in Fifth-Century Literature. London.

Humphreys, S.C. (1993) The Family, Women, and Death. Comparative Studies. $2^{\text {nd }}$ ed. London.

_ (1988) 'The Discourse of Law in Archaic and Classical Greece.' Law and History Review. 6: $465-493$.

(1981) 'Death and Time' in Mortality and Immortality: Anthropology and Archaeology of Death (S.C. Humphreys and H. King eds.) London. 261 - 284.

(1980) 'Family Tombs and Tomb Cult in Ancient Athens: Tradition or Traditionalism?' Journal of Hellenic Studies. 100: 96 - 126. 
95.

(1974) 'The Nothoi of Kynosarges.' Journal of Hellenic Studies. 94: 88 -

Hurwit, J. (2007a) 'The Problem with Dexileos: Heroic and Other Nudities in Greek Art.' American Journal of Archaeology. 111: 35 - 60.

_ (2007b) 'The Human Figure in Early Greek Sculpture and Vase Painting.' in The Cambridge Companion to Archaic Greece. (H.A. Shapiro ed.) Cambridge. 265 - 286.

— (1999) The Athenian Acropolis: History, Mythology, and Archaeology from the Neolithic Era to the Present. Cambridge and New York, NY.

Irwin, E. (2005) Solon and Early Greek Poetry: The Politics of Exhortation. Cambridge.

Jacoby, F. (1944a) 'Genesia: A Forgotten Festival of the Dead.' Classical Quarterly. 38: 65 - 75.

(1944b) 'Patrios Nomos: State Burials in Athens and the Public Cemetery and the Kerameikos.' Journal of Hellenic Studies. 64: 37 - 66.

Jeffery L. H. (1976) Archaic Greece. The City-States, c. 700-500 B.C. London.

(1962) 'The Inscribed Gravestones of Archaic Attica.' The Annual of the British School at Athens. 57: 115 - 53.

Johansen, K.F. (1951) The Attic Grave- Reliefs of the Classical Period. Copenhagen.

Just, R. (1989) Women in Athenian Law and Life. London and New York, NY.

Kamen, D. (2007) 'The Life Cycle in Archaic Greece.' in The Cambridge Companion to Archaic Greece. (H.A. Shapiro ed.) Cambridge. 85 - 110.

Karo, G. (1943) An Attic Cemetery. Philadelphia, PA.

Kosmopoulou, A. (2002) The Iconography of Sculptured Statue Bases in the Archaic and Classical Periods. Madison, WI.

— (2001) “Working Women': Female Professionals on Classical Attic Gravestones.' The Annual of the British School at Athens. 96: 281 - 319.

Kurtz, D.C. (1975) Athenian White Lekythoi: Patterns and Painters. Oxford.

Kurtz, D. C. and Boardman, J. (1971) Greek Burial Customs. Ithaca, NY.

Kyle, D.G. (1987) Athletics in Ancient Athens. Leiden. 
Lambert, S.D (2002) 'Parerga III: The Genesia, Basile and Epops Again.' Zeitschrift Für Papyrologie Und Epigraphik. 139: 75 - 82.

Lapatin, K. (2007) 'Art and Architecture.' in The Age of Pericles (L.J Samons II ed.) New York, NY. $153-178$.

Lape, S. (2004) Reproducing Athens: Menander's Comedy, Democratic Culture, and the Hellenistic City. Princeton, NJ.

_ (2002/3) 'Solon and the Institution of the Democratic Family Form.' Classical Journal. 98: 117 - 139.

Leader, R.E. (1997) 'In Death Not Divided: Gender, Family, and State on Classical Athenian Grave Stelae.' American Journal of Archaeology. 101: 683 -699 .

Lewis, J. (2007) Greek Law Givers. London.

_ (2006) Solon the Thinker: Political Thought in Archaic Athens. London.

Loraux, N. (1993) The Children of Athena. (trans. from French by C. Levine) Princeton, NJ.

_ (1987) Tragic Ways of Killing a Woman. Cambridge, MA. and London.

_ (1986) The Invention of Athens. Cambridge, MA.

MacGregor, G. (1992) Images of Afterlife: Beliefs from Antiquity to Modern Times. New York, NJ.

Macintosh, F. (1994) Dying Acts: Death in Ancient Greek and Modern Irish Tragic Drama. Cork.

Mertens, J. (1977) Attic White-ground: Its Development on Shapes other than Lekythoi. New York, NY.

Meyer, E.A. (1993) 'Epitaphs and Citizenship in Classical Athens.' Journal of Hellenic Studies. 113: 99 - 121.

Millet, P. (1998) 'The Rhetoric of Reciprocity in Classical Athens' in Reciprocity in Ancient Greece. (C. Gill, N. Postlethwaite, and R. Seaford eds.) New York, NY.

Mitchell, L. and Rhodes, P.J. (eds.) (1997) The Development of the Polis in Archaic Greece. London and New York, NY.

Morgan, C. (1993) 'The Origins of Pan-Hellenism' in Greek Sanctuaries: New Approaches. (N. Marinatos and R. Hägg eds) London. 
Morris, I. (1994) 'Everyman's Grave'' in Athenian Identity and Civic Ideology (A. Scafuro and A. Boegehold eds.) $67-101$.

_ (1992) Death-Ritual and Social Structure in Classical Antiquity. Ithaca, New York.

— (1992/3) 'Law, Culture, and Funerary Art in Athens 600-300BC.' in Hephaistos. 12: $35-50$.

(1989) 'Attitudes Toward Death in Archaic Greece.' Classical Antiquity. 8: $296-320$.

— (1987) Burial and Ancient Society: The Rise of the Greek City-State. New York.

Morris, S.P. (1992) Daidalos and the Origins of Greek Art. Princeton, NJ.

Nagy, G. (1990) Greek Mythology and Poetics. Ithaca, NY.

Nielsen, T.H., Bjertrup, L., Hansen, M.H., Rubenstein, L. \& Vestergrad, T. (1989) 'Athenian Grave Monuments and Social Class.' Greek, Roman and Byzantine Studies. 30: 411 - 420.

Nightingale, A.W. (1995) Genres in Dialogue: Plato and the Construct of Philosophy. New York, NY.

Oakley, J.H. (2004) Picturing Death in Classical Athens: The Evidence of the White Lekythoi. New York, NY.

Ober, J. (1998) 'The Athenian Revolution of 508/7 B.C.E.: Violence, Authority, and the Origins of Democracy.' in Cultural Poetics in Archaic Greece: Cult, Performance, Politics. (C. Dougherty and L. Kurke eds.) New York, NY. $215-$ 232.

(1989) Mass and Elite in Democratic Athens: Rhetoric, Ideology, and the Power of the People. Princeton, NJ.

Ochs, D.J. (1993) Consolatory Rhetoric: Grief, Symbol, and Ritual in the Greco-Roman Era. Columbia, NY.

Ogden, D. (2002) 'Controlling Women's Dress: Gynaikonomoi' in Women's Dress in the Ancient Greek World (L. Llewellyn-Jones ed.) Lylandysul. 203225.

Oliver G. J. (2000) 'Athenian Funerary Monuments: Style, Grandeur, and Cost.' in The Epigraphy of Death: Studies in the History and Society of Greece and Rome. Liverpool. 59 - 80.

O'Rourke, D. (2007) 'Mourning Becomes Eclectic: Death of Communal Practice in a Greek Cemetery.' American Ethnologist. 34: 387 - 402. 
Osborne, R. (2004a) 'Monumentality and Ritual in Archaic Greece' in Ritual Poetics. (D. Yatromanolakis and P. Roilos eds.) Washington, DC. 37 - 55.

(2002) 'Archaic Greek History' in Brill's Companion to Herodotus (I. de Jong and H. van Wees eds.) Leiden. 497 - 520.

_ (1998a) Archaic and Classical Greek Art. Oxford.

_ (1998b) 'Sculpted Men of Athens.' in Thinking Men: Masculinity and its Self-Representation in the Classical Tradition. (L. Foxhall and J. Salmon eds.) London and New York, NY. 23 - 42.

- (1997a) 'Law and Laws: How Do We Join Up the Dots.' in The Development of the Polis in Archaic Greece (L.G. Mitchell and P.J. Rhodes eds.) London and New York, NY. $74-82$.

(1997b) 'Law and the Democratic Citizen and the Representation of Women in Classical Athens' Past and Present. 155: 3 - 33.

Osborne, R. (1988) 'Death Revisited; Death Revised. The Death of the Artist in Archaic and Classical Greece.' Art History. 11: 1 - 16

Ostwald, M. (1969) Nomos and The Beginnings of The Athenian Democracy. Oxford.

Palagia, O. (ed.) (2006) Greek Sculpture: Function, Materials, and Techniques in the Archaic and Classical Periods. New York, NY.

Parke, H.W. (1977) Festivals of the Athenians. London.

Parker, R. (2005) Polytheism and Society at Athens. New York, NY.

\section{Oxford.}

(1983) Miasma: Pollution and Purification in Early Greek Religion.

Patterson, C.B. (2007) 'Other Sorts: Slaves, Foreigners, and Women in Periclean Athens.' in The Age of Pericles (L.J Samons II ed.) New York, NY. $153-178$.

- (2006a) 'Citizen Cemeteries' in Classical Athens?' Classical Quarterly. 56: $48-56$.

_ (2006b) 'The Place and Practice of Burial in Sophocles' Athens' Helios. 33S: $9-48$.

— (1981) Pericles' Citizenship Law of 451-450BC. Salem, NH.

Petropoulou, A. (1988) 'The Interment of Patroklos (Iliad 23.252-57).' The American Journal of Archaeology. 1988: 482 - 495. 
Philips, D.D. (2004) Athenian Political Oratory: 16 Key Speeches. New York, NY.

Pomeroy, S.B. (1997) Families in Classical and Hellenistic Greece. Oxford.

Pritchett, W.K. (1985) The Greek State at War IV. Berkley, CA.

Randall, B. (2004) Solon: The Lawmaker of Athens. New York, NY.

Rehm, R. (1994) Marriage to Death: The Conflation of Wedding and Funeral Rituals in Greek Tragedy. Princeton, NJ.

Rhodes, P.J. and Osborne, R. (eds.) (2003) Greek Historical Inscriptions 404 323 BC. Oxford.

Richter G. M. A. (1961) The Archaic Gravestones of Attica. London.

— (1945) 'Peisistratos' Law Regarding Tombs.' American Journal of Archaeology. 49: 152.

Ridgway, B.S. (1981) Fifth Century Styles In Greek Sculpture. Princeton, NJ.

_ (1977) The Archaic Style in Greek Sculpture. Princeton, NJ.

Robben, A.C.G.M. (ed.) (2004) Death, Mourning, and Burial: a Cross-Cultural Reader. Malden, MA.

Roberts, H.S. (2002) 'Pots for the Living, Pots for the Dead.' Acta Hyperborea. 9: $9-32$.

Robertson, M. (1975) A History of Greek Art. Cambridge.

Rohde, E. (1925) Psyche: The Cult of Souls and Belief in Immortality among the Ancient Greeks. Chicago, IL.

Roller, L.E. (1981) 'Funeral Games in Greek Art.' American Journal of Archaeology. 85: 107 - 119.

Roselli, D. K. (2006) 'Polyneices' Body and His Monument: Class, Social Status, and Funerary Commemoration in Sophocles' Antigone.' Helios. 33S: $135-178$.

Roy, J. (1999) 'Polis and Oikos in Classical Athens.' Greece and Rome. 46: 1 18.

Rubin, G. (1975) 'The Traffic in Women: Notes on the 'Political Economy' of Sex', in Toward an Anthropology of Women (R. Reiter ed) New York, NY. 157 -210 . 
Ruschenbusch, E. (1966) Nomoi: die Fragmente des Solonischen Gesetzeswerkes. Wiesbaden.

Sallares, R. (1991) The Ecology of the Ancient Greek World. Ithaca, NY.

Scafuro, A.C. (2006) 'Identifying Solonian Laws' in Solon of Athens: New Historical and Philosophical Approaches. (Blok, J. and A. Lardinois eds.) Leiden. 175 - 196.

Schmaltz, B. (1983) Griechische Grabreliefs. Darmstadt

Seaford, R. (1994) Reciprocity and Ritual: Homer and Tragedy in the Developing City State. Oxford.

Segal, C. (1971) The Theme of the Mutilation of the Corpse in the Iliad. Leiden.

Shanks, M. (1999) Art and the Early Greek State: An Interpretive Archaeology. Cambridge.

Shapiro, H.A. (ed.) (2007) The Cambridge Companion to Archaic Greece. Cambridge.

— (1991) 'The Iconography of Mourning in Athenian Art.' American Journal of Archaeology. 95: 629 - 656.

Simms, R. (1997/8) 'Mourning and Community at the Athenian Adonia.' The Classical Journal. 93: 121 - 141.

Small, D.B. (1995) 'Monuments, Laws, and Analysis: Combining Archaeology and Text in Ancient Athens.' in Methods in the Mediterranean. Historical and Archaeological Views on Texts and Archaeology. (D.B. Small ed.) Leiden. 143 $-174$.

Smith, G. (1919) 'Athenian Casualty Lists' Classical Philology. 14: 351 - 364.

Snodgrass, A. (1980) Archaic Greece: The Age of Experiment. London.

_ (1977) Archaeology and the Rise of the Greek State. Cambridge.

Sourvinou-Inwood, C. (1995) "Reading" Greek Death: To the End of the Classical Period. Oxford.

(1983) 'A Trauma in Flux: Death in the Eight Century and After' in The Greek Renaissance. (R. Hägg ed.) Stockholm. $33-48$.

Stears, K. (2008) 'Death Becomes Her: Gender and Athenian Death Ritual' in Lament: Studies in the Ancient Mediterranean and Beyond. (A. Suter ed.) Oxford and New York, NY. 139 - 155. 
— (2000) 'Developments in Fifth-Century Funerary Sculpture' in The Epigraphy of Death: Studies in the History and Society of Greece and Rome. (G.J. Oliver ed.) Liverpool. 25 - 58.

(1998) 'Death Becomes Her: Gender and Athenian Death Ritual' in The Sacred and the Feminine in Ancient Greece. New York, NY. 113 - 127.

(1995) 'Dead Women's Society: Constructing Female Gender in Classical Athenian Funerary Sculpture.' in Time, Tradition and Society in Greek Archaeology. (N. Spencer ed.) London. 109 - 131.

Stieber, M. (2004) The Poetics of Appearance in the Attic Korai. Austin, TX.

Steiner, D.T. (2001) Images in Mind: Statues in Archaic and Classical Greek Literature and Thought. Princeton, NJ.

Stewart, A. (1990) Greek Sculpture: An Exploration. New Haven, CT.

Strauss, B.S. (1986) Athens After the Peloponnesian War: Class, Faction and Policy 403-386 B.C. London.

Stupperich, R. (1994) 'The Iconography of Athenian State Burials in the Classical Period.' in The Archaeology of Athens and Attica Under the Democracy. (W.D.E. Coulson, O. Palagia, T.L. Shear, Jr., H.A. Shapiro and F.J. Frost eds.) Oxford. 93 - 103.

Suter, A. (2003) 'Lament in Eurpides' Trojan Women.' Mnemosyne. 56: 1-28

Sutton, R.F. jr. (2004) 'Recognizing the "Oikos" on Attic Red-Figure Pottery.' Hesperia Supplements. 33: 327 - 350.

Svenbro, J. (1993) Phrasikleia: An Anthropology of Reading in Ancient Greece. (trans. from French by J. Lloyd) Ithaca, NY.

Szegedy-Maszak, A. (1998) 'Thucydides' Solonian Reflections.' in Cultural Poetics in Archaic Greece: Cult, Performance, Politics. (C. Dougherty and L. Kurke eds.) New York, NY.

Thomas, R. (1989) Oral Tradition and Written Record in Classical Athens. Cambridge.

Todd, S.C. (1996) Sparta and Athens. London.

Todd, S.C. and Millett, P. (1990) 'Law, Society and Athens' in Nomos Essays in Athenian Law, Politics and Society. (P. Millet and S.C. Todd eds.) Cambridge. $1-18$.

Toher, M. (1991) 'Greek Funerary Legislation and the Two Spartan Funerals' in Georgica (M.A. Flower and M. Toher eds.) London. 159 - 175. 
van Wees, H. (1998) 'A Brief History of Tears: Gender Differentiation in Archaic Greece.' in When Men Were Men : Masculinity, Power, and Identity in Classical Antiquity. (L. Foxhall and J. Salmon eds.) London and New York, NY. $10-53$.

Vermeule, E. (1979) Aspects of Death in Early Greek Art and Poetry. Berkeley, CA.

Vernant, J.-P. (1980) Myth and Society in Ancient Greece. Sussex.

Princeton.

(1991) Mortals and Immortals: Collected Essays. (F. Zeitlin ed.)

Vestergaard, T. (2000) 'Milesian Immigrants in Late Hellenistic and Roman Athens.' in The Epigraphy of Death: Studies in the History and Society of Greece and Rome. (G.J Oliver ed.) Liverpool. 81 - 110.

Walcot, P. (1973) 'The Funeral Speech, a Study of Values.' Greece and Rome. 20: $111-121$.

Walters, K.R. (1983) 'Perikles' Citizenship Law.' Classical Antiquity. 2: 614 336.

(1980) 'Rhetoric as Ritual: The Semiotics of the Attic Funeral Oration.' Florilegium 2: 1 - 27.

Whitehead, D. (1977) The Ideology of the Athenian Metic. Cambridge.

Whitley, J. (2001) The Archaeology of Ancient Greece. Cambridge. (1994) 'The Monuments that Stood Before Marathon: Tomb Cult and Hero Cult in Archaic Attica.' American Journal of Archaeology. 98: 213 - 230.

Wycherley, R.E. (1978) The Stones of Athens. Princeton, NJ.

Young, R. (1951) ‘Sepulutrae Intra Urbem.’ Hesperia. 20: 67 - 134.

Ziolkowski, J.E. (1981) Thucydides and the Tradition of Funeral Speeches at Athens. New York. 


\section{Appendix 1}

Greek and Latin sources and translations are taken from Blok (2006) 197 - 247 unless otherwise stated. I have adopted my own numbering system.

\section{$\underline{\text { Athenian Laws }}$}

1. [Demosthenes] 43.62 (Against Makartatos)

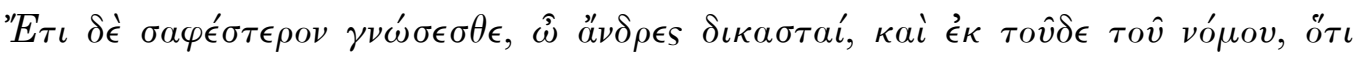

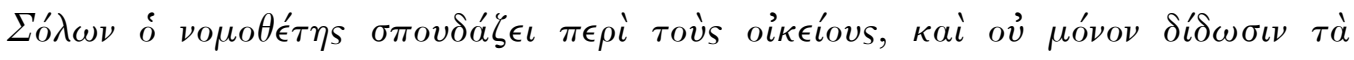

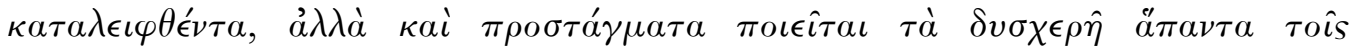

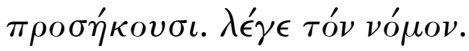

\section{NOMO $\Sigma$}

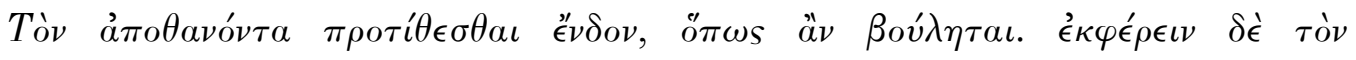

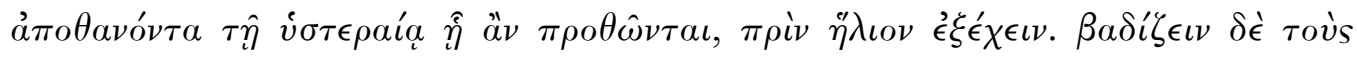

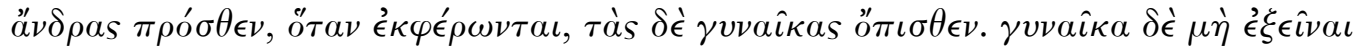

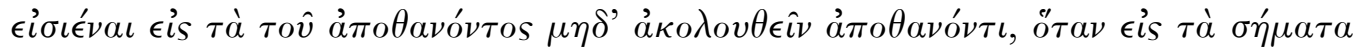

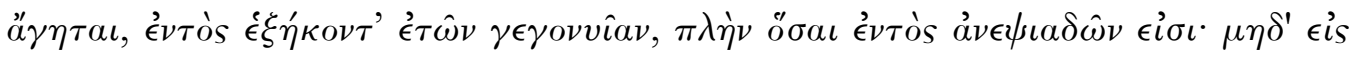

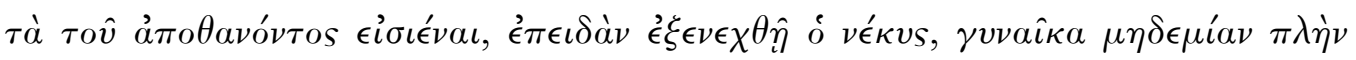

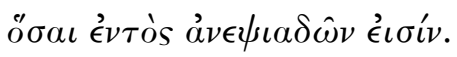

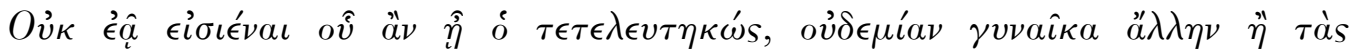

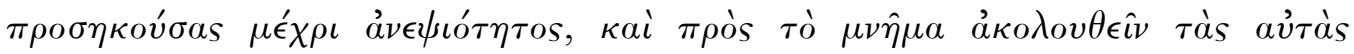

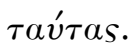

You will understand even more clearly, men of the jury, from the following law, that the lawgiver Solon is very much in earnest in regard of those who are relatives (oikєiovs), and not only gives them the property left by the deceased, but also lays upon them all the burdensome obligations. Read the law. 
The Law

The deceased is to be laid upon a bier ( $\pi \rho \sigma i \theta \epsilon \sigma \theta a \iota$; to conduct a prothesis) inside, in any fashion one wishes. The next day after the prothesis, the deceased

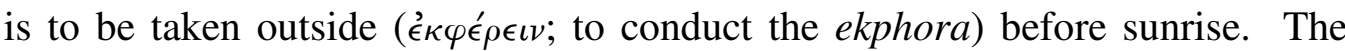
men are to walk in front, when the dead are carried out for burial, the women in the rear. It is forbidden for a woman to enter the house of the deceased and to follow a corpse when it is taken to the grave when she is under sixty years, except those women who are close relatives (in the degree of second cousin). Neither is it allowed for any woman to enter the house of the deceased, when the corpse has been carried out for burial, except women who are close relatives.

The law does not allow any women to enter the room where the deceased lies, other than close relatives to the degree of second cousins, and [it allows] the same women to follow to the tomb.

2. Demosthenes. 20.104.

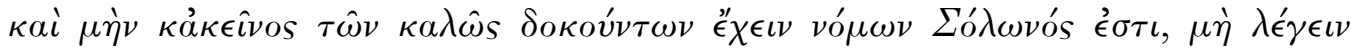

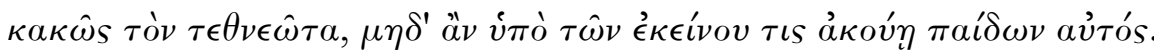

And certainly there is another highly regarded law of Solon, that one should not speak ill of the dead, even if someone hears himself spoken ill of by the dead man's children.

3. Plutarch Life of Solon. 21.1-2.

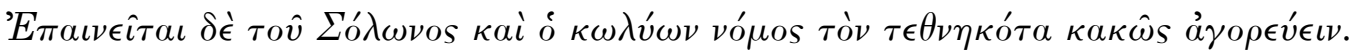

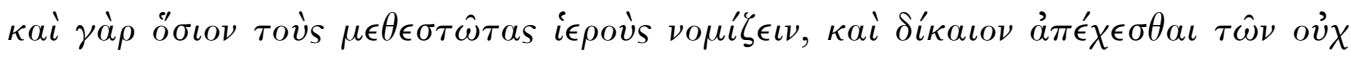

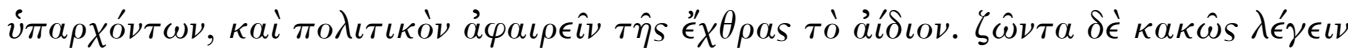

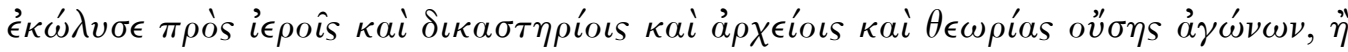

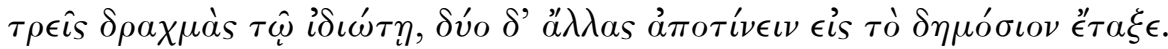


Praise is given also to that law of Solon which forbids speaking ill of the dead. For it is piety to regard the deceased as sacred, justice to spare the absent, and good policy to rob hatred of its perpetuity. He also forbade speaking ill of the living in temples, courts-of-law, public offices, and at public spectacles; the transgressor must pay three drachmas to the person injured, and two more into the public treasury.

4a. Cicero. De Legibus. 2.59.

Iam cetera in XII minuendi sumptus sunt lamentationisque funebris, translata de Solonis fere legibus. 'Hoc plus,' inquit, 'ne facito: rogum ascea ne polito'. Nostis quae secuntur. Discebamus enim pueri XII ut carmen necessarium, quas iam nemo discit. Extenuato igitur sumptu tribus riciniis et tunicla purpurea et decem tibicinibus tollit etiam lamentationem: "mulieres genas ne radunto neve lessum funeris ergo habento'. Hoc veteres interpretes Sex. Aelius, L. Acilius non satis se intellegere dixerunt, sed suspicari vestimenti aliquod genus funebris, L. Aelius lessum quasi lugubrem eiulationem, ut vox ipsa significant. Quad eo magis iudico verum esse quia lex Solonis id ipsum vetat. Haec laudabilia et locupletibus fere cum plebe communia. Quod quidem maxime e natura est, tolli fortunae discrimen in morte.

There are other rules, too, in the Twelve Tables, which provide for the limitation of the expense and the mourning at funerals, which were borrowed for the most part from the laws of Solon. The law says this: 'Do no more than this: do not smooth the pyre out with an axe.' You know what follows. For we learned the law of the Twelve Tables in our boyhood as a required formula; though no one learns it nowadays. The expense, then, is limited to three veils, a purple tunic, and then pipe players; the mourning is also limited: "women shall not tear their cheeks, nor have a lessus at a funeral. The older interprets, Sextus Aelius and Lucius Acilius, admitted that they did not fully understand this, but suspected that it referred to some kind of a mourning garment. Lucius Aelius thought a lessus was a sort of sorrowful wailing, for that is what the word would seem to signify. I incline to the latter interpretation, since this is the very thing 
forbidden in Solon's laws. These provisions are praiseworthy and applicable in general both to the rich and common people. For it is quite in accordance with nature that differences in wealth should cease with death.

4b.Idem. 2.60:

Cetera item funerbria, quibus luctus augetur XII sustulerunt. 'Homini' inquit 'mortuo ne ossa legito, quoi pos funus faciat'. Excipit bellicam peregrinamque mortem. Haec praeterea sunt in legibus: [de uncturaque] 'Servilis unctura tollitur omnisque circumpotatio'. Quae et recte tolluntur nisi fuissent. 'Ne sumptuosa respersio, ne longae coronae, ne acerrae' praetereantur.

Other funeral customs likewise, which tend to increase grief, are forbidden by the Twelve Tables. One of these says: 'A dead man's bones shall not be gathered up so that a funeral may be held late'. Here an exception is made in case of death in war or on foreign soil. These laws also contain the following provisions: [about anointing and?] 'Anointing by slaves is prohibited and also any sort of drinking-bout'. It is quite proper that these things should have been abolished, and the law would not have forbidden them unless they had actually occurred. Let us pass over the prohibition: 'No costly sprinkling, or long garlands, or censers'.

4c. idem. 2.63-66.

Sequebantur epulae quas inihant propinqui coronati, apud quos de mortui laude quom siquid veri erat praedicatum - nam mentiri nefas habebatur - , iusta confecta erant. Postea quom, ut scribit Phalereus <Demetrius $>$, sumptuosa fieri funera et lamentabilia coepissent, Solonis lege sublata sunt, quam legem eisdem prope verbis nostri Xviri in decimam tabulam coniecerunt. Nam de tribus riciniis et pleraque illa Solonis sunt. De lamentis vero expressa verbis sunt: 'Mulieres genas ne radunto neve lessum funeris ergo habento'.

De sepulcris autem nihil est apud Solonem amplius quam 'ne quis ea deleat neve alienum inferat', poenaque est, 'si quis bustum - nam id puto appellari 
$\tau v ́ \mu \beta o v$ - aut monimentum' inquit 'aut columnam violarit deiecerit fregerit'. Sed post aliquanto propter has amplitudines sepulcrorum, quas in Ceramico videmus, lege sanctum est, 'ne quis sepulcrum faceret operosius quam quod decem homines effecerint triduo', neque id opere tectorio exornari nec hermas hos quos vocant licebat inponi, nec de mortui laude nisi in publicis sepulturis, nec ab alio nisi qui publice ad eam rem constitutus esset dici licebat. Sublata etiam erat celebritas virorum ac mulierum, quo lamentatio minueretur; auget enim luctum concursus hominum. Quocirca Pittacus omnino accedere quemquam vetat in funus aliorum. Sed ait rursus idem Demetrius increbruisse eam funerum sepulcrorumque magnificentiam quae nunc fere Romae est. Quam consuetudinem lege minuit ipse.

[A discourse on the oldest law of Cecrops on funerals] A feast followed at which the near relatives were crowned with garlands; and on this occasion, after the praiseworthy deeds of the deceased had been commemorated, if this could be done with truthfulness - for it was considered wicked to give false praise-, the proper rites were performed. Later, according to Demetrius of Phaleron, when extravagance in expenditure and mourning grew up, it was abolished by the law of Solon, a law which our decemvirs took over almost word for word and placed in the Tenth Table. For what it contained about the three veils, and most of the rest, comes from Solon. In regard to mourning they have followed his wording exactly: 'Women shall not tear their cheeks or have a lessus at the funeral. But Solon has no other rules about graves except one to the effect that 'no one is to destroy them or place the body of a stranger in them', and a penalty is fixed 'in case anyone violates, throws down, or breaks a burial mound - for that, I think, is what he means by tumbos - or monument or column'. But somewhat later (post aliquanto), on account of the enormous size of the tombs, which we see in the Kerameikos, a law was issued that "no tomb should be built that is more lavish than it would take ten men the space of three days to complete', and it should not be adorned with a plaster covering (opus tectorium) and that no herms, as they are called, should be placed on them; and it was not allowed that the praise of the dead was spoken of except at public burials and by no one else but who had been officially appointed for this purpose. The gathering of large numbers of men and women was also forbidden, in order to 
limit the mourning, for a crowd increases grief. It was for this reason that Pittacus forbade anyone at all who did not belong to the family to attend a funeral. But the same Demetrius says that the magnificence of funerals and tombs had increased again, as almost to equal that of Rome at present. This custom he himself restricted by law.

5. Plutarch. Life of Solon 21.5-7.

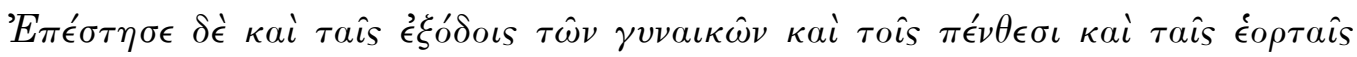

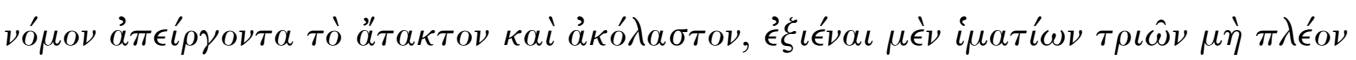

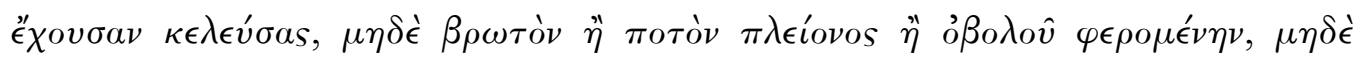

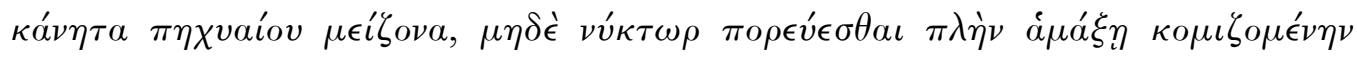

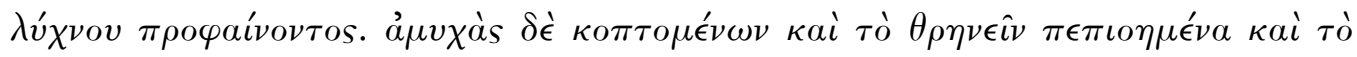

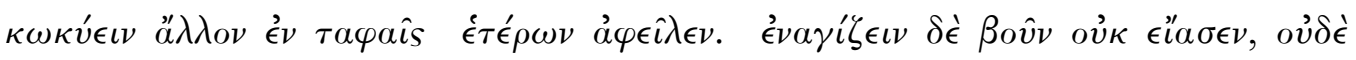

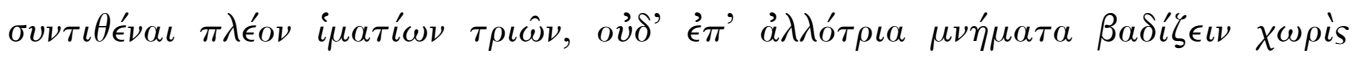

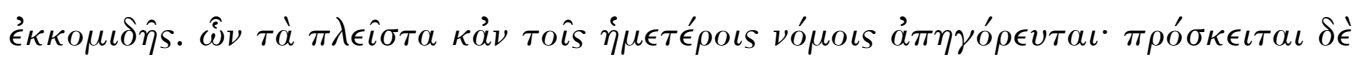

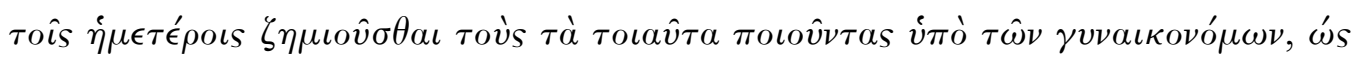

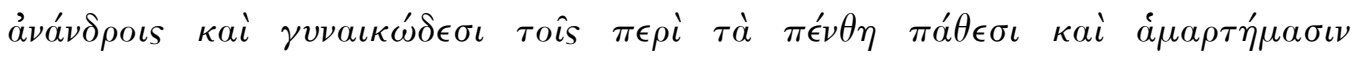

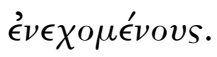

He [Solon] also made a regulation on the public appearances (exodoi) of women and their mourning and their festivals in a law which put an end to disorder and to licence, ordering that a woman should not go out with more than three pieces of clothing, and carrying no more food or drink than the value of an obol, and a basket not larger than a cubit, and that they should not travel at night except in a wagon bringing a lighted lamp. He put an end to (self-inflicted) wounding of mourners, and the singing of dirges (threnein) and the bewailing of someone at the funeral of others. He did not allow the sacrifice (enagizein) of an ox at the grave, nor to five more than three pieces of clothing as a grave gift, nor to visit (a grave) of others except during a funeral. Most of these practices are also prohibited by our laws, but our laws have an additional statement that men who do such things are to be punished by the gynaikonomoi, because they engage in unmanly and effeminate affects in their mourning and thus do wrong. 


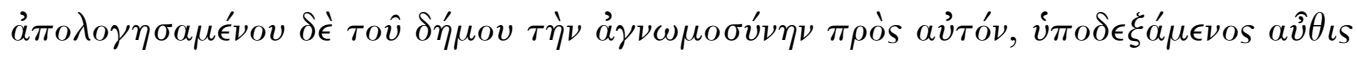

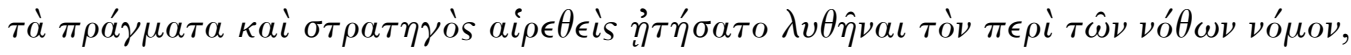

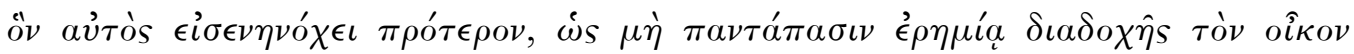

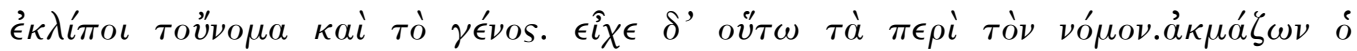

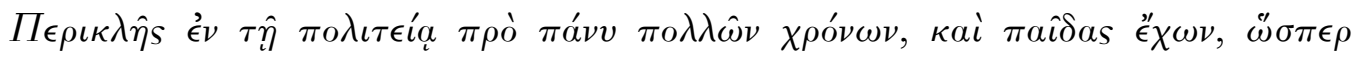

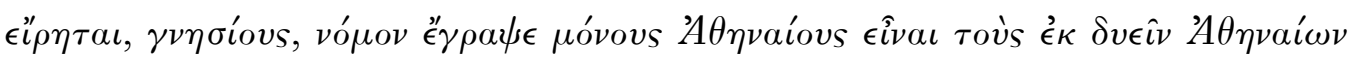

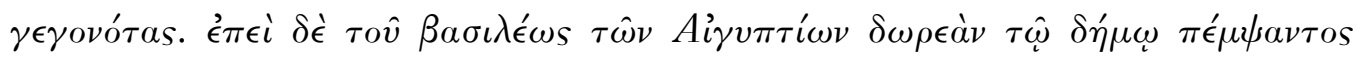

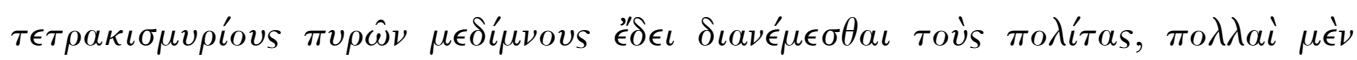

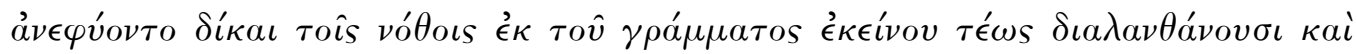

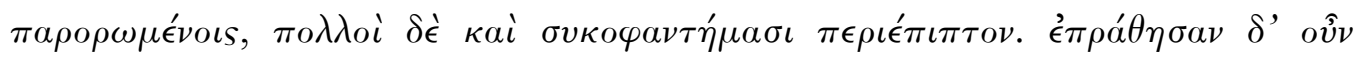

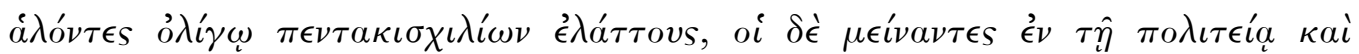

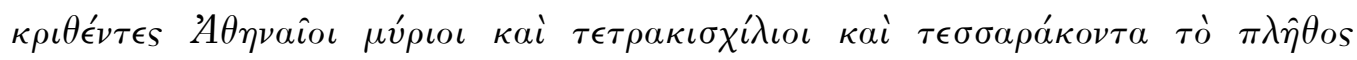

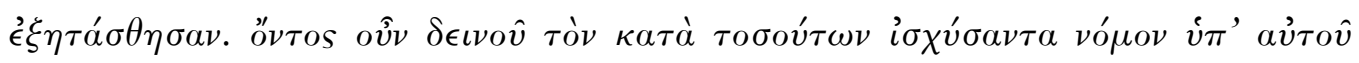

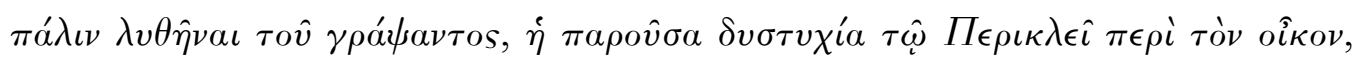

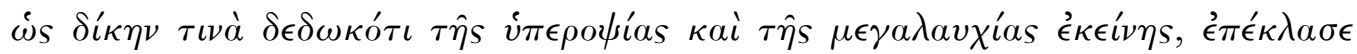

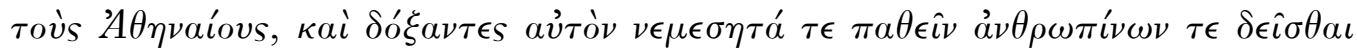

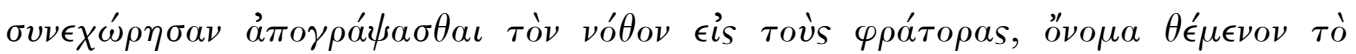
aí $\sigma \hat{v}$.

When the people had apologized for their thankless treatment of him, and he had undertaken again the conduct of the state, and been elected general, he asked for a suspension of the law concerning children born out of wedlock, - $a$ law which he himself had formerly introduced,-in order that the name and lineage of his house might not altogether expire through lack of succession.

The circumstances of this law were as follows. Many years before this, when Pericles was at the height of his political career and had sons born in wedlock, as I have said, he proposed a law that only those should he reckoned Athenians whose parents on both sides were Athenians. And so when the king of Egypt sent a present to the people of forty thousand measures of grain, and this had to 
be divided up among the citizens, there was a great crop of prosecutions against citizens of illegal birth by the law of Pericles, who had up to that time escaped notice and been overlooked, and many of them also suffered at the hands of informers. As a result, a little less than five thousand were convicted and sold into slavery, and those who retained their citizenship and were adjudged to be Athenians were found, as a result of this scrutiny, to be fourteen thousand and forty in number. It was, accordingly, a grave matter, that the law which had been rigorously enforced against so many should now be suspended by the very man who had introduced it, and yet the calamities which Pericles was then suffering in his family life, regarded as a kind of penalty which he had paid for his arrogance and haughtiness of old, broke down the objections of the Athenians. They thought that what he suffered was by way of retribution, and that what he asked became a man to ask and men to grant, and so they suffered him to enroll his illegitimate son in the phratry-lists and to give him his own name. This was the son who afterwards conquered the Peloponnesians in a naval battle at the Arginusae islands, and was put to death by the people along with his fellow-generals. (trans. Perrin)

\section{Epigraphical Sources of Comparable Laws.}

\section{Regulation of the Labyadai in Delphi}

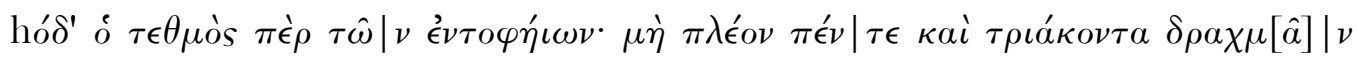

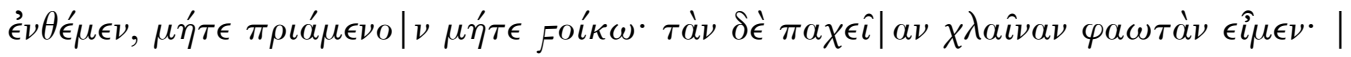

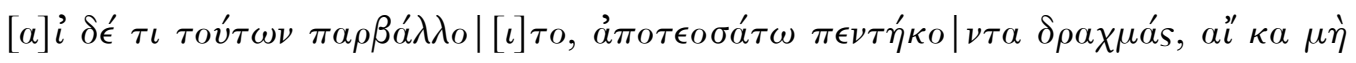

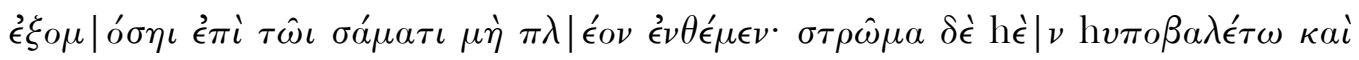

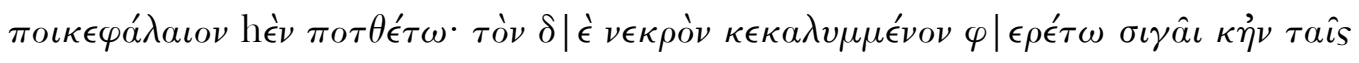

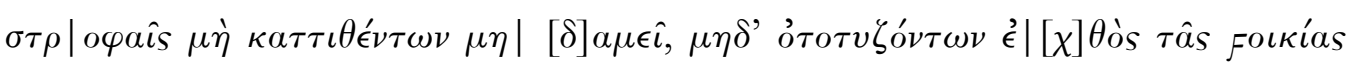

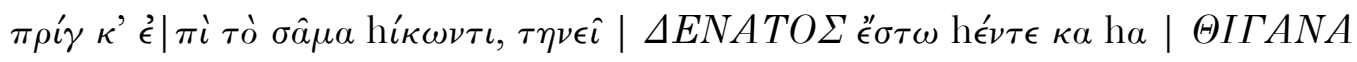

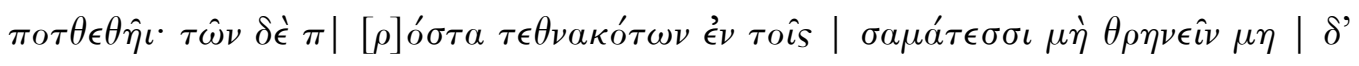

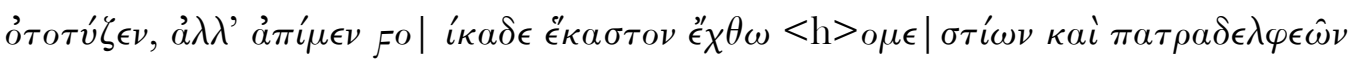

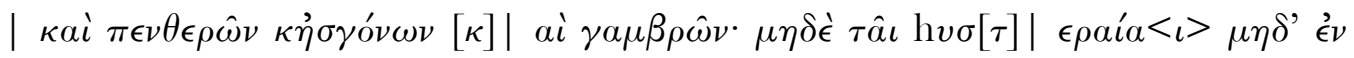




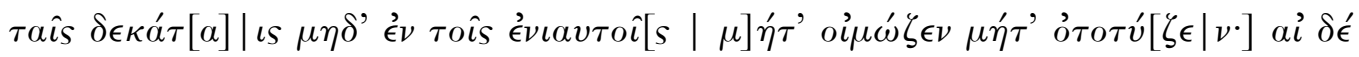

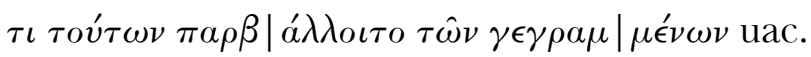

This is the ordinance (thesmos) about funerals. No more than 35 drachmae are to be put in(side), either bought or from home. The thick garment (chlaine) is to be of a light colour (phaotos); and if someone violates one of these things, he must pay a fine of 50 drachmae, unless he swears by the grave that there is no more put in(side). Let one plaid (stroma) be put under (the corpse) and let a pillow be added. The covered body must be carried in silence and in the turnings they should never put it down, and there must be no wailing outside the house before arrival at the grave; let there be a denatos (?) until the thigana (?) is/are laid down; for the earlier dead in the graves there should be no singing of dirges (threnein) nor wailing (ototuzein), but let everyone go home except those of the same hearth and paternal uncles and father-in-law, brothers-in-law and offspring and sons-in-law. Neither on the next day nor on the tenth nor on the year's celebrations there should be lamenting (oimozein) or wailing (ototuzein). And if someone violates anything of these regulations...

8a. Funeral regulation from Ioulis on Keos. Second half of the fifth century B.C.E.

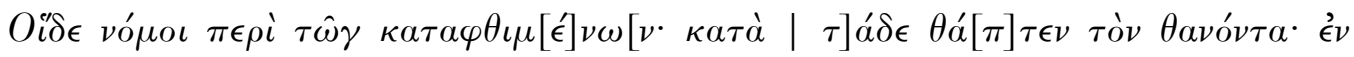

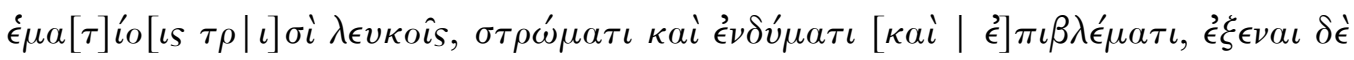

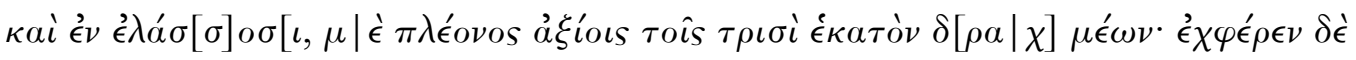

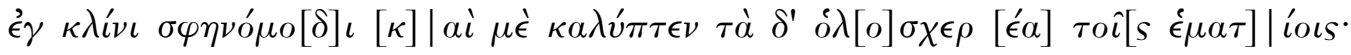

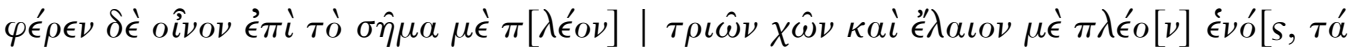

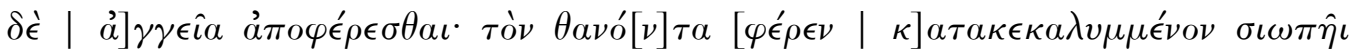

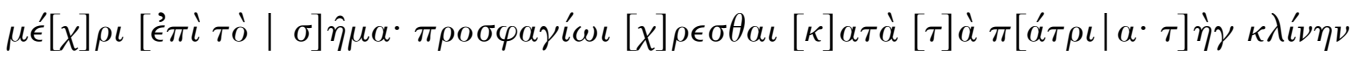

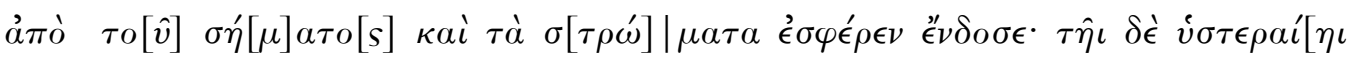

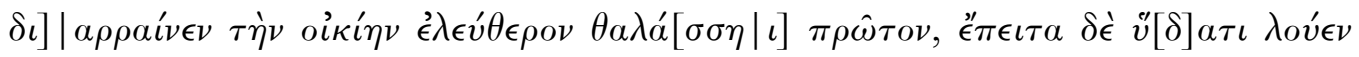

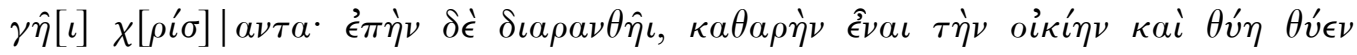

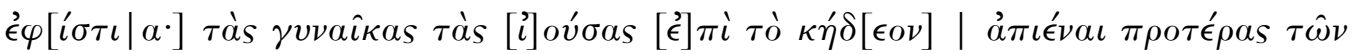

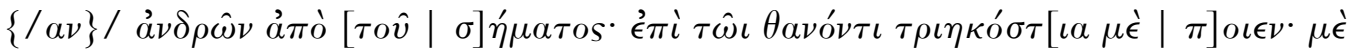




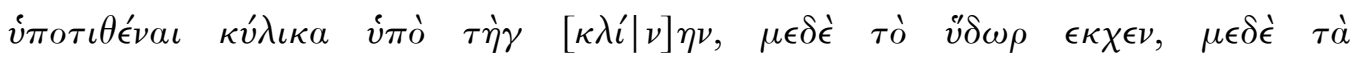

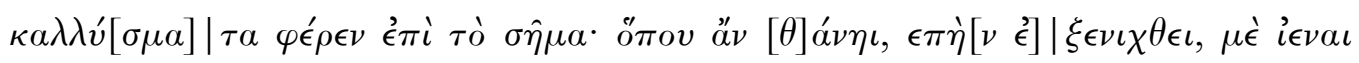

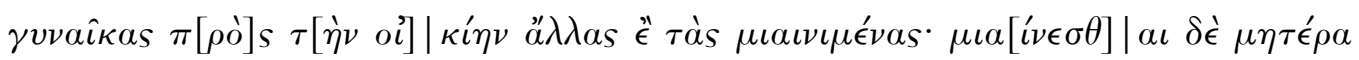

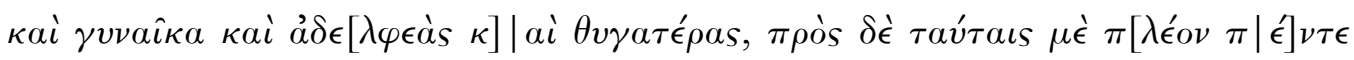

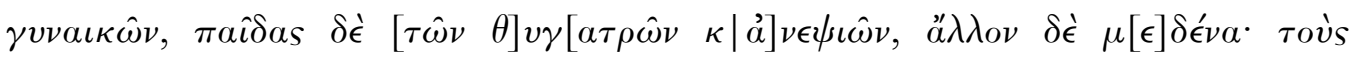

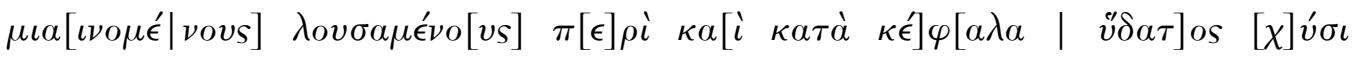
$\kappa \alpha[\theta \alpha \rho]$ ov̀s $\hat{\varepsilon} v \alpha \iota \epsilon \omega \iota[---$

These are the laws (nomoi) about the dead. The deceased is to be buried as follows: in three white garments, the strôma, the endyma and the epiblêma; it is allowed also in fewer; but the three together of a value no more that 100 drachmae; carry the corpse out for burial (ekpherein) on a bier with pointed (?) legs and do not cover the parts of the bier (?) with the shrouds; bring no more that three chous wine to the grave and one of oil, the vessels must be removed; the deceased must be covered and taken in silence to the grave; hold a preliminary sacrifice (prosphagion) according to tradition; the bier and the plaids (strômata) are to be taken from the grave indoors; the next day a freeman is first to purify the house with seawater; next after rubbing the house with earth he is to wash it with clear water. After the purification the house is pure again and a sacrifice is to take place at the hearth. The women who have come to the funeral are to leave the cemetery before the men. Do no make a triêkostiasacrifice for the dead. One should not put a cup beneath the bier nor pour water out nor bring sweepings of brooms to the tomb. When someone has died and after the carrying out of the corpse, no other women are to enter the house except those women who are already polluted; let the polluted women be the mother and the wife and the sisters and the daughters, and added to those not more than five women, and the children (piadas) of the daughters and the second-degree cousins, but no one (allon) else. All those who are polluted (tous mia[inomenous]) are purified when they have washed themselves all over their body and head with pourings of water... 
$8 b$.

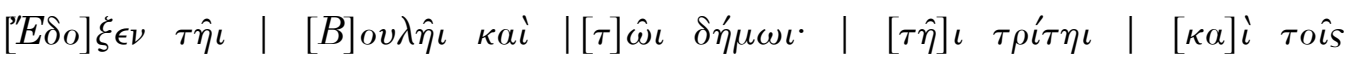

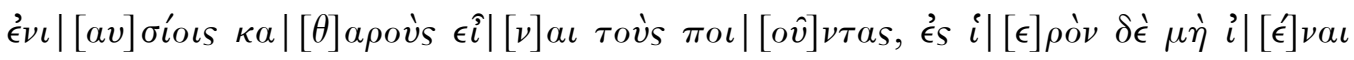

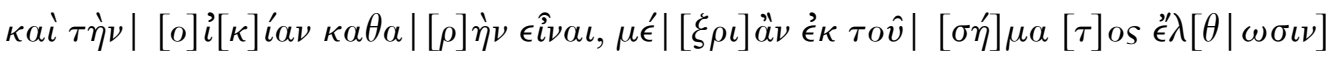

The boulê and the dêmos have decided: that those who do (commemoration) on the third day and on the yearly (celebration) are pure, but they shall not enter a sanctuary, and the house is not pure until they have gone from the grave.

9a. Gortyn.

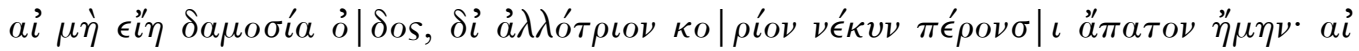

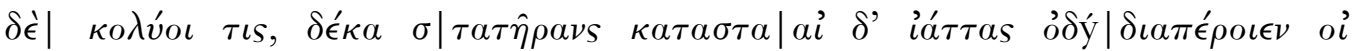
$\kappa \alpha \delta \mid\left[\epsilon \sigma \tau \alpha i^{----}\right.$

If there is no public road, let there be no punishment for those who carry the body over the land of another; if someone hinders this, let him pay ten staters; but if, while there is a road, the relatives are to carry over.

\section{9b. Gortyn}

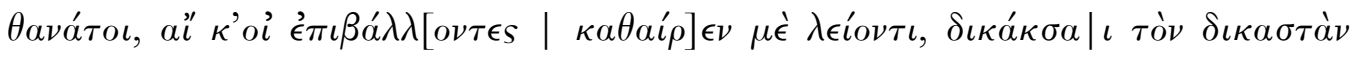

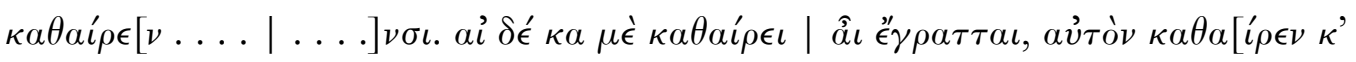

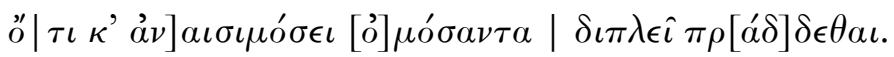

...to death; if the next of kin do not want to purify, the judge will decide to purify...If (the one to do so) does not purify as is prescribed, he [the judge] is to do the purification himself; and whatever he will need (to do so), he will charge under oath in double amount to (the heirs). 


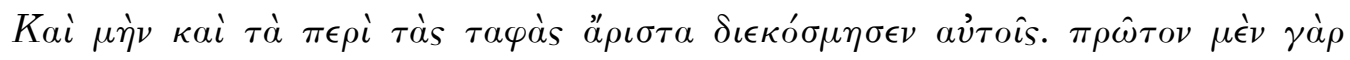

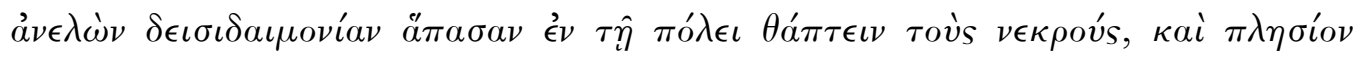

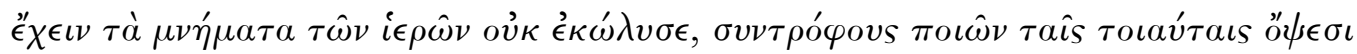

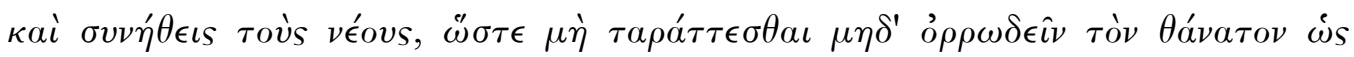

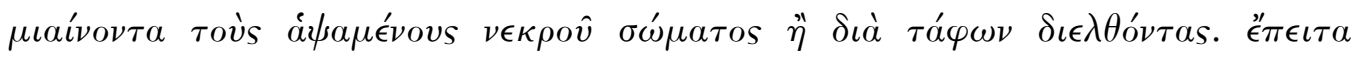

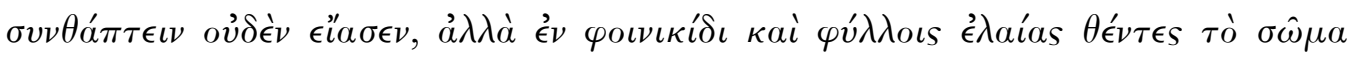

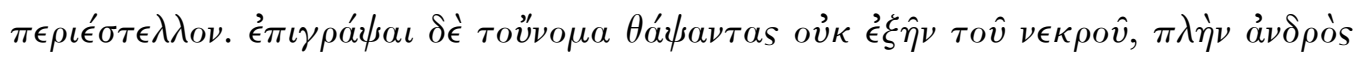

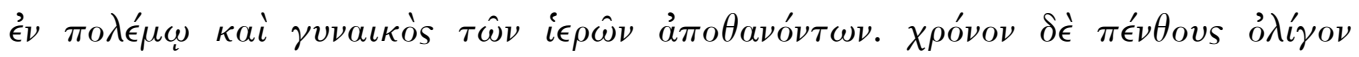

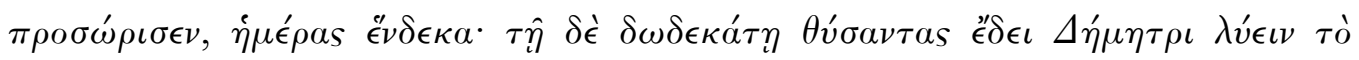
$\pi \alpha ́ \theta o s$.

Furthermore, Lycurgus made most excellent regulations in the matter of their burials. To begin with, he did away with all superstitious terror by allowing them to bury their dead within the city, and to have memorials of them near the sacred places, thus making the youth familiar with such sights and accustomed to them, so that they were not confounded by them, and had no horror of death as polluting those who touched a corpse or walked among graves. In the second place, he permitted nothing to be buried with the dead; they simply covered the body with a scarlet robe and olive leaves when they laid it away. 2 To inscribe the name of the dead upon the tomb was not allowed, unless it were that of a man who had fallen in war, or that of a woman who had died in sacred office. He set apart only a short time for mourning, eleven days; on the twelfth, they were to sacrifice to Demeter and cease their sorrowing. (trans. Perrin)

\section{Plutarch's Institua laconica 238d}

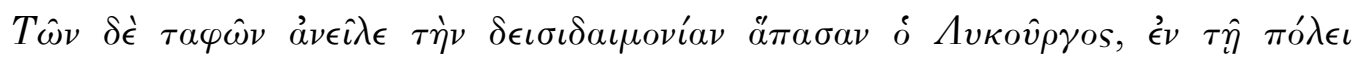

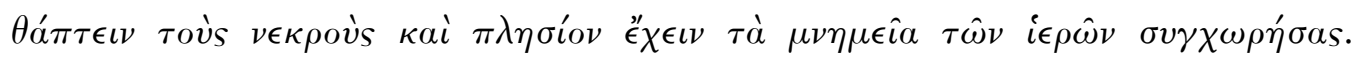

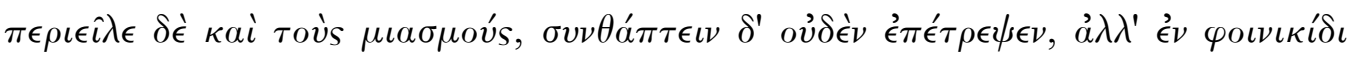




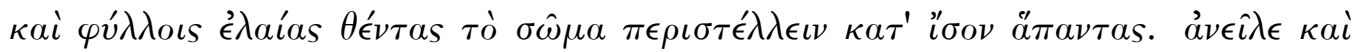

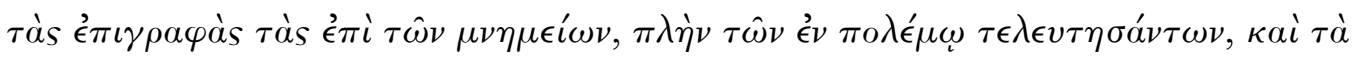

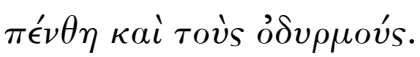

Lycurgus did away with all superstitious fear connected with burials, granting the right to bury the dead within the city, and to have the tombs near the shrines. He also abolished the pollutions associated with death and burial. He permitted the people to bury nothing with the dead, but only to enfold the body in a red robe and olive leaves, and all to treat their dead alike. He also did away with the inscriptions on tombs, except of those who had met their end in war, and also did away with mourning and lamentation. (trans. Perrin) 


\section{Appendix 2}

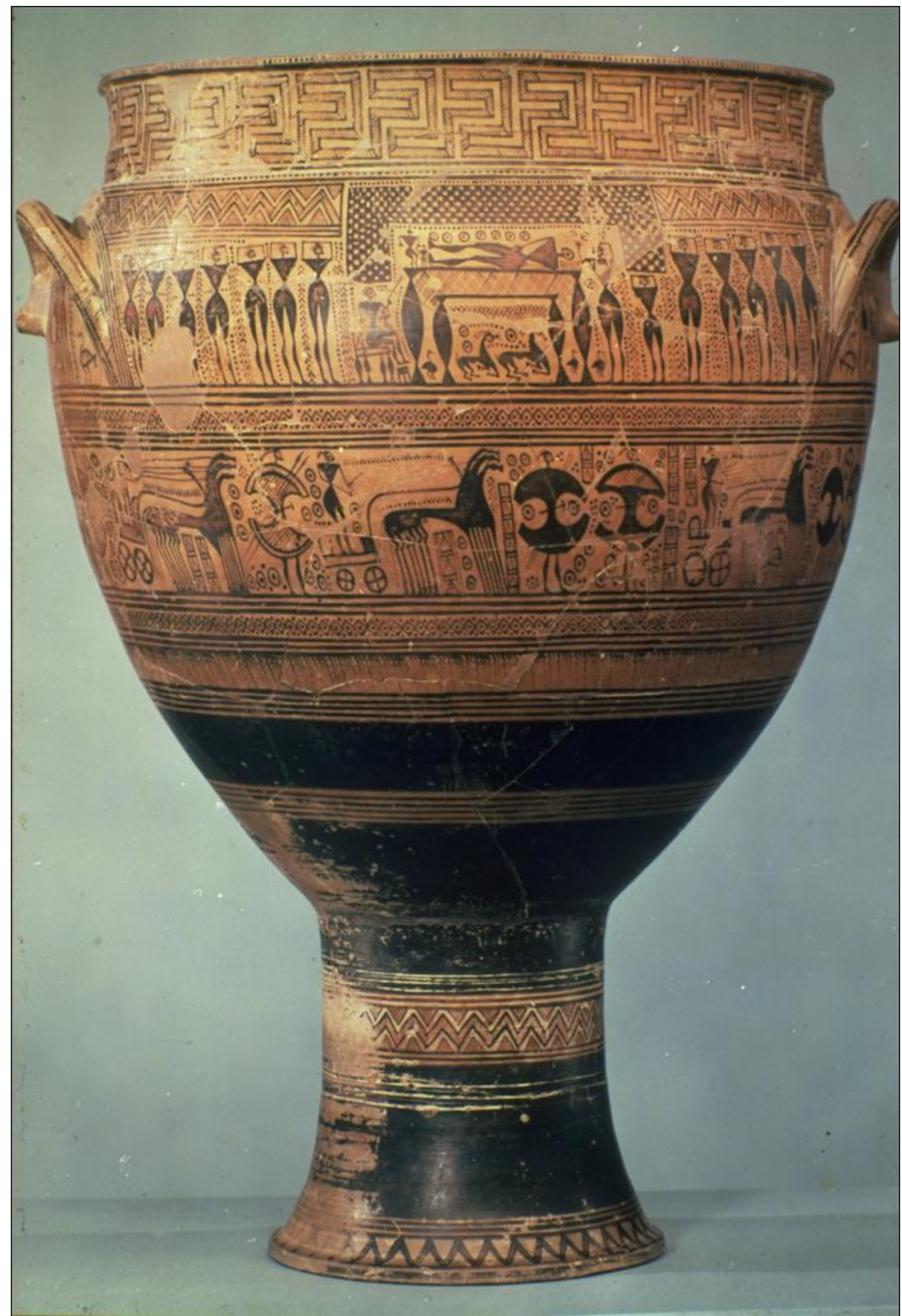

Fig. 1: Dipylon Cemetery, Athens. Geometric funerary krater. Scenes of ritual mourning (prothesis) and funeral procession of chariots. c. 750 B.C.E. New York, MMA 14.130.140. Artstor.org. I.D.: AIC_960032 downloaded on 21.08.2009. 


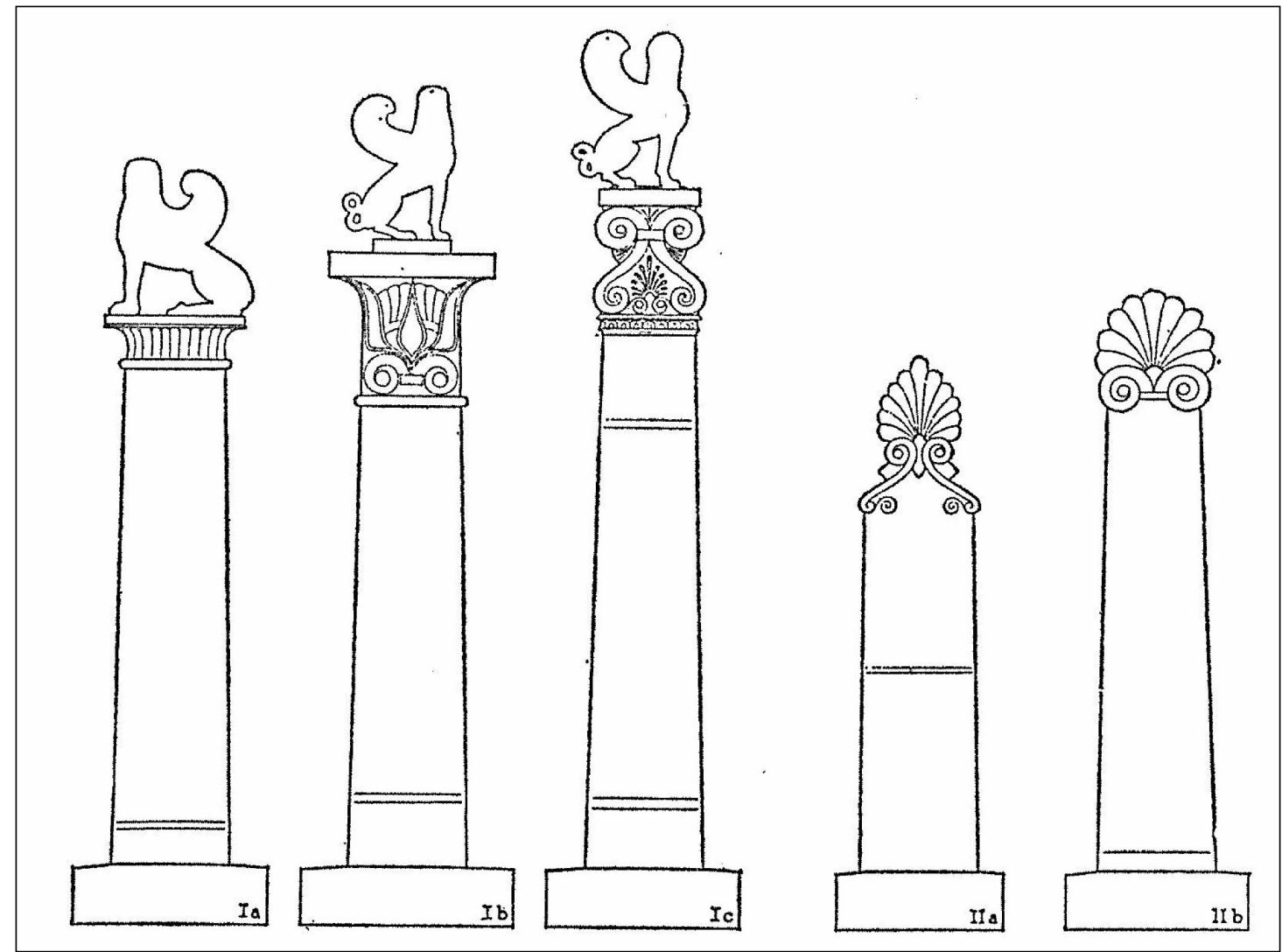

Fig. 2: Attic grave stelae of Type I, a, b, c, about 610-525 B.C.E.; of Type II, a, b, about 530-500 B.C.E.; and of Type IIc, about 450 B.C.E. Drawings by L.F. Hall. Richter (1961) 3.

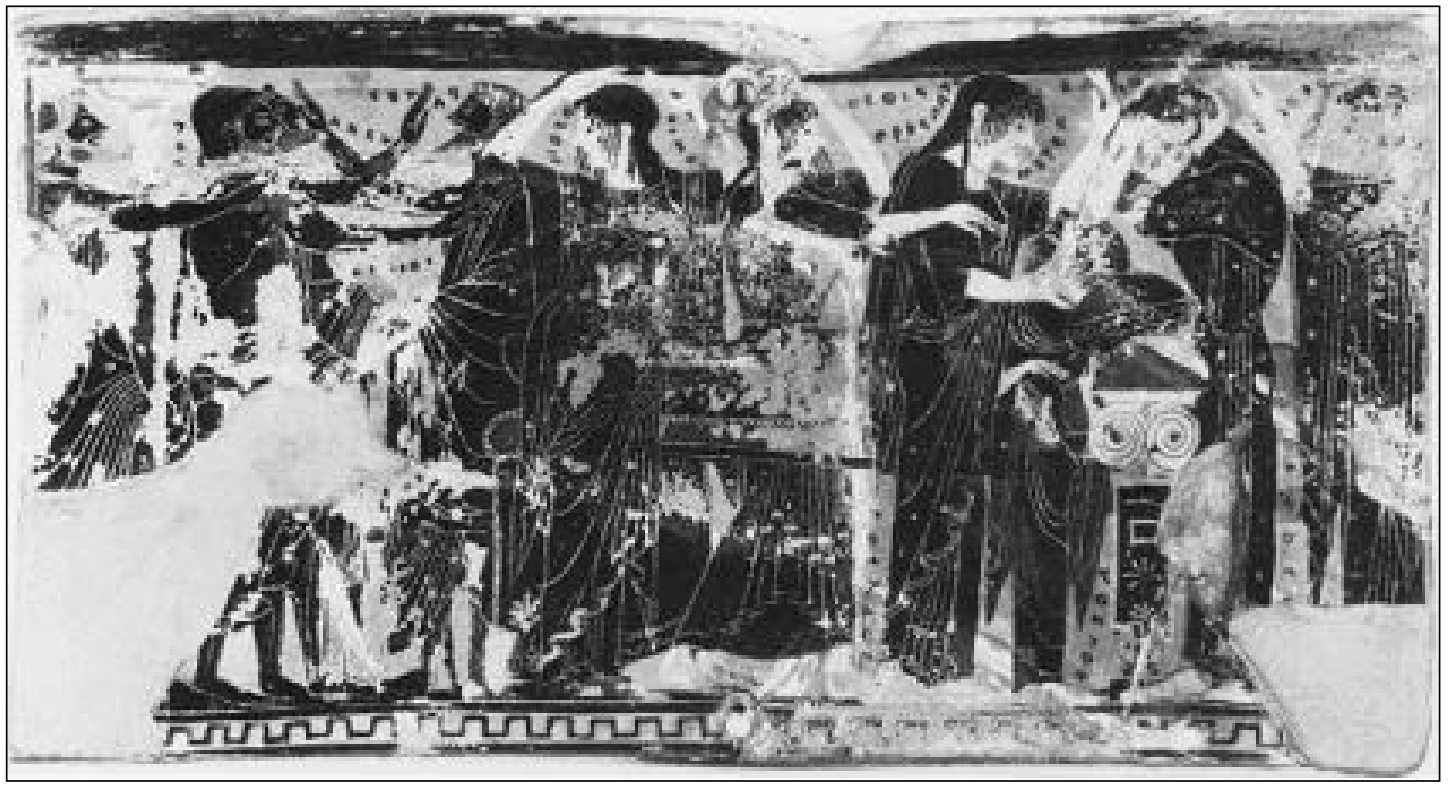

Fig. 3: Black-figure plaque. Prothesis. c. 500 B.C.E. Paris, Lourve. L.4 (MNB 905) from van Wees (1998) Fig. 1.17. 


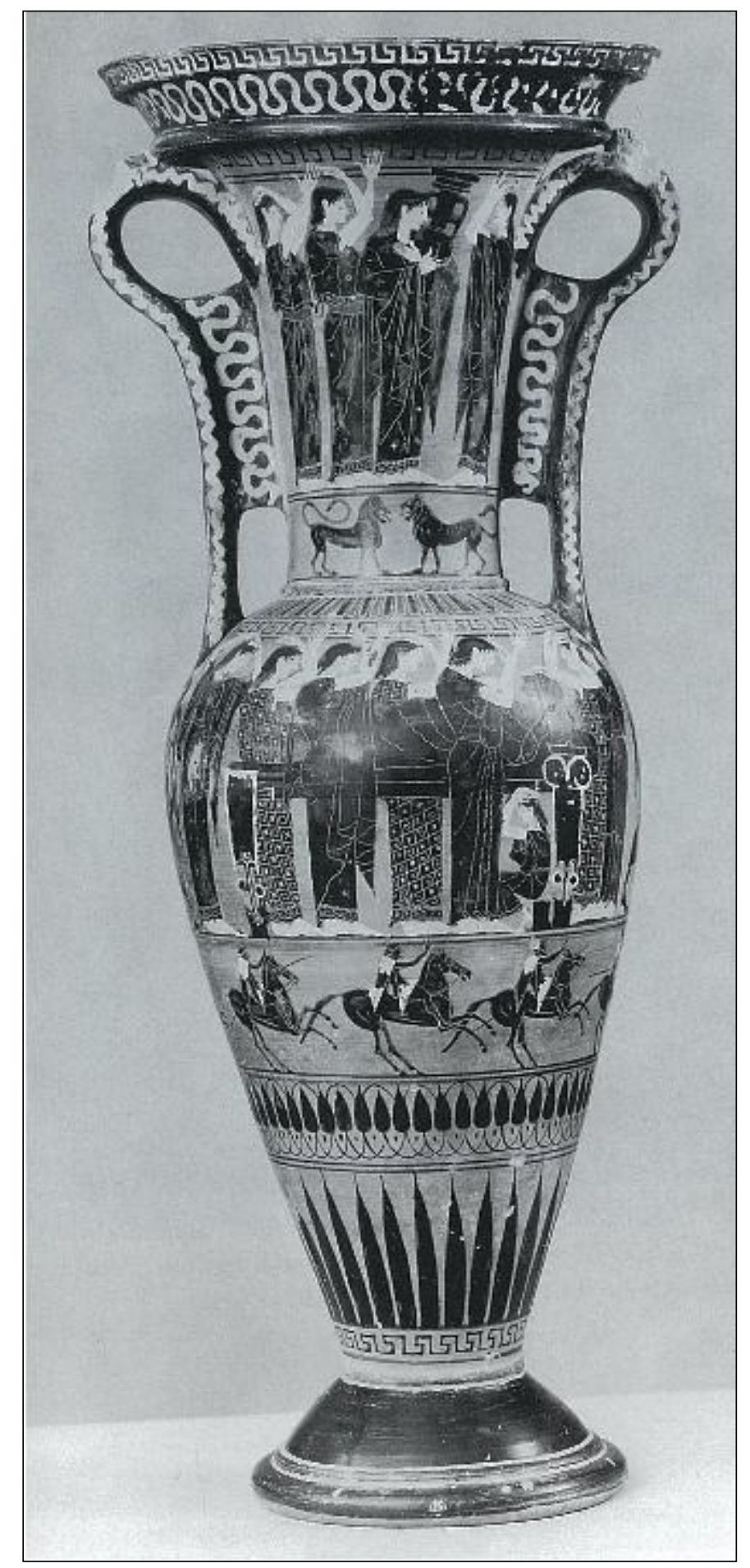

Fig. 4: Attica. Attic black-figure loutrophoros. Prothesis. Late sixth century B.C.E. New York, MMA 22.228. Kamen (2007) Fig. 14. 


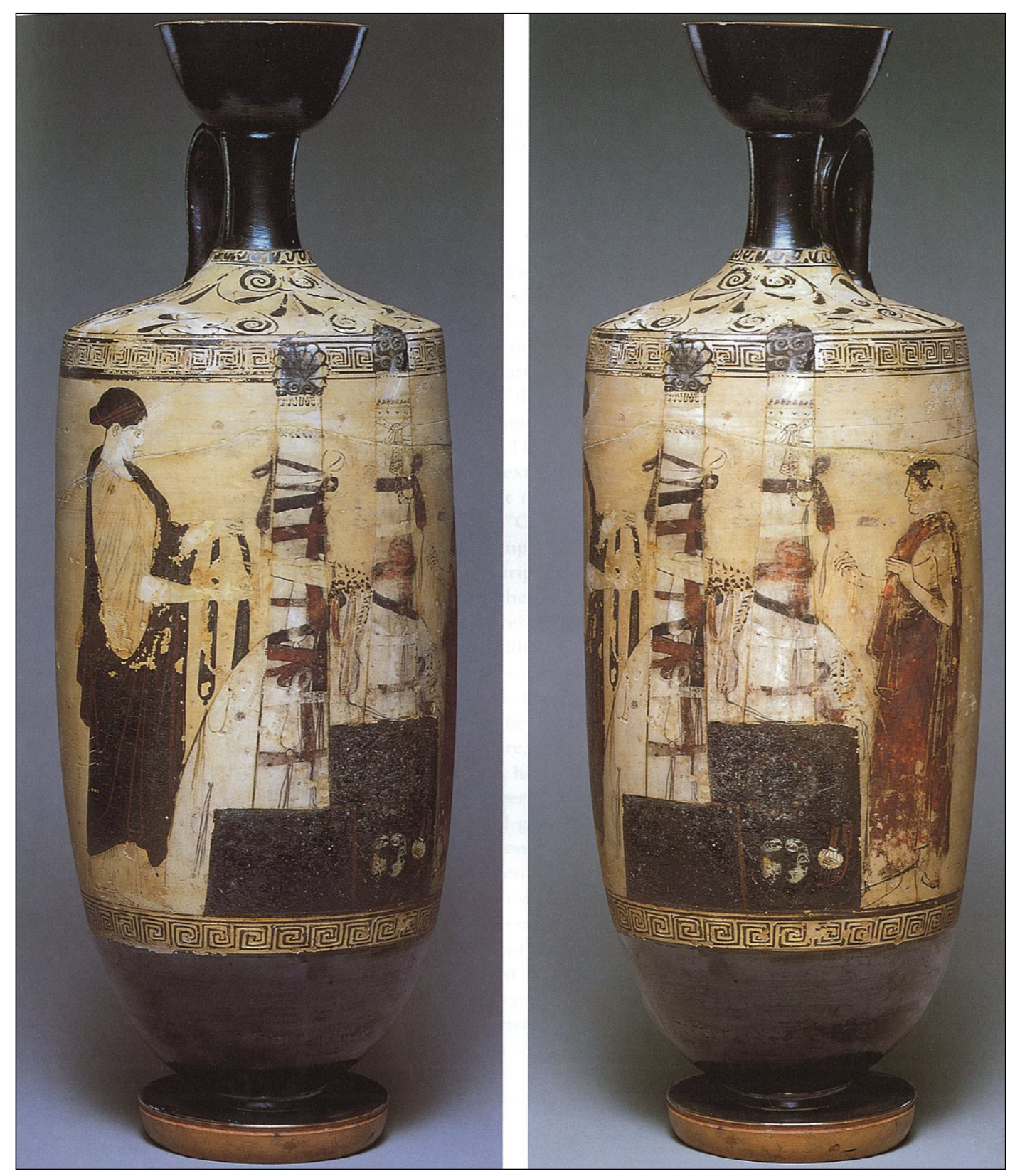

Fig. 5: Attic white lekythos, Vouni Painter. Visit to the grave. c. 460 B.C.E. New York, MMA 35.11.5. Oakley (2004) VII A-B. 


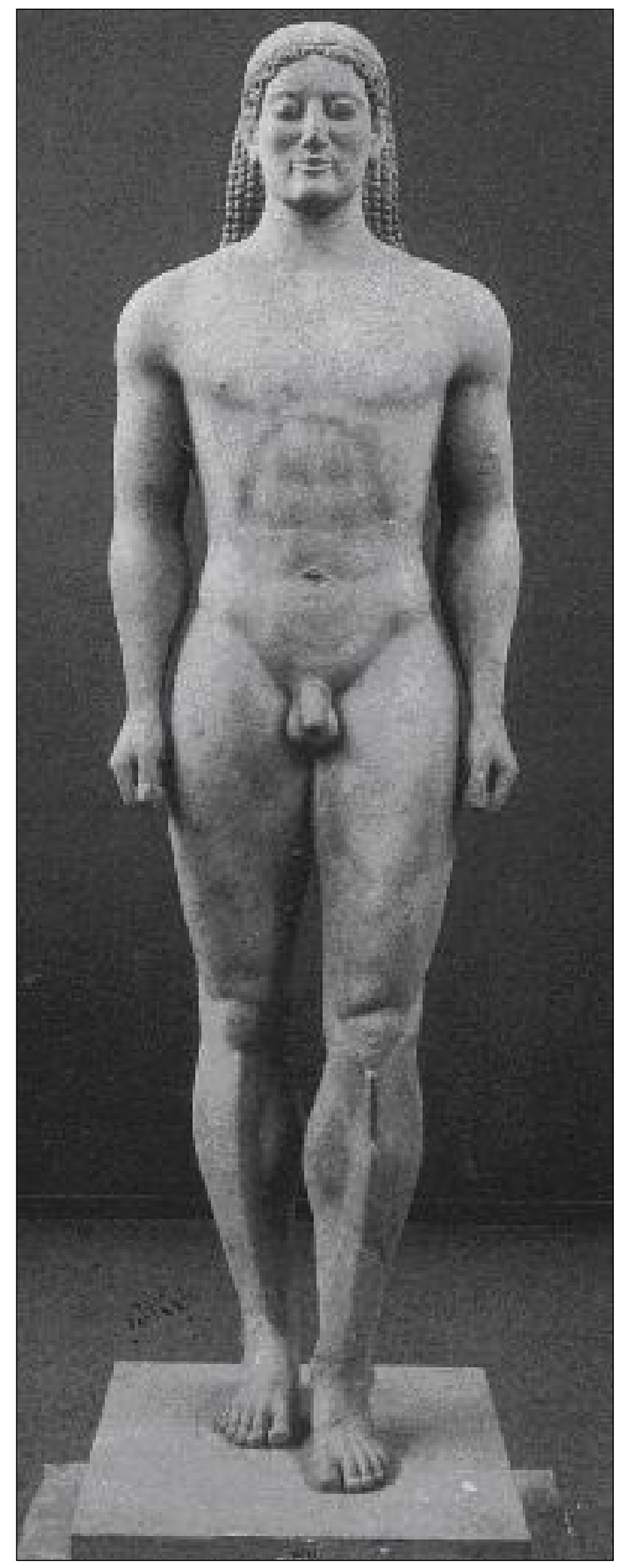

Fig. 6: Anavysos. Kouros from tomb of Kroisos. c. 530 B.C.E. Athens, NM 3851. Hurwit (2007b) Fig. 35. 


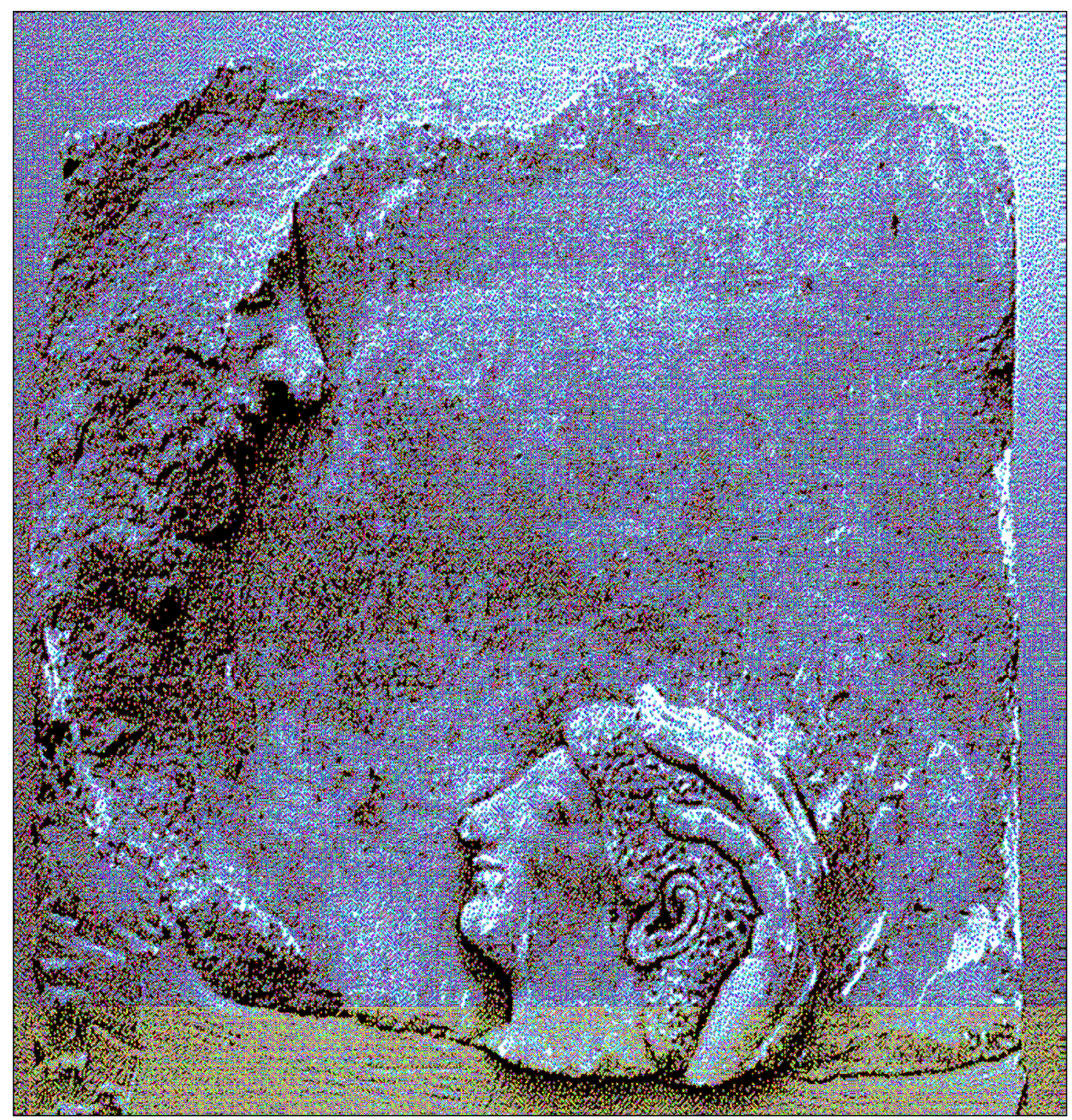

Fig 7: Athens. Grave stele. Mother and child; the stele was likely for the child (or for mother and child.) c. 530 B.C.E. Athens, NM 4472. Schmaltz (1983) tf. 3,1 . 


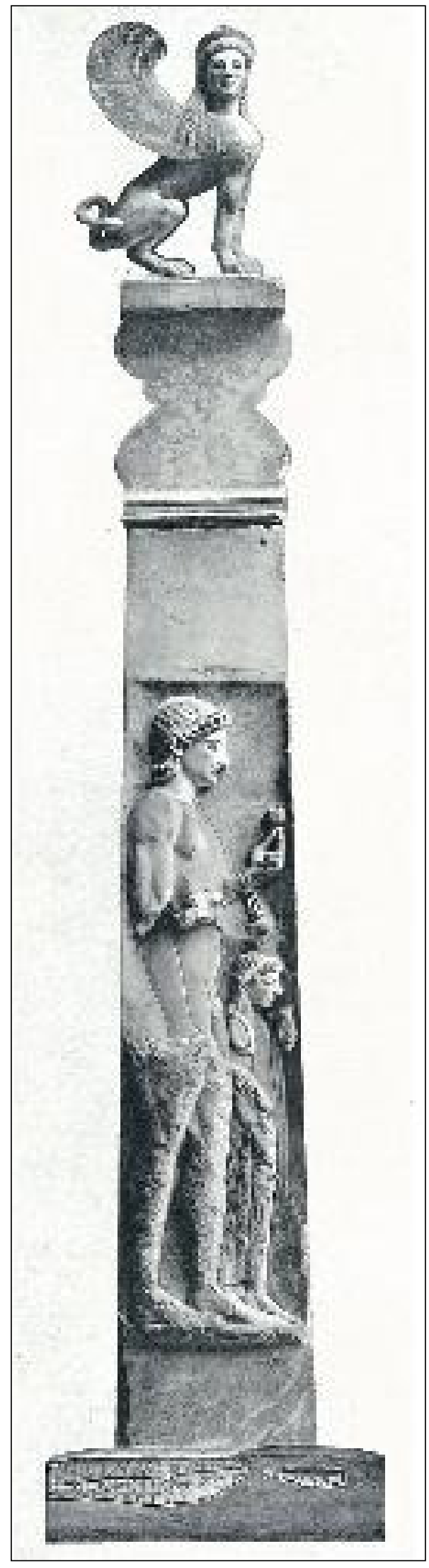

Fig. 8: Attica. Grave stele, youth and little girl. c. 550-525 B.C.E. New York, MMA 11.185 (Head, shoulder and left hand of the girl are plaster copies from the original in Berlin.) Richter (1961) Fig. 99. 


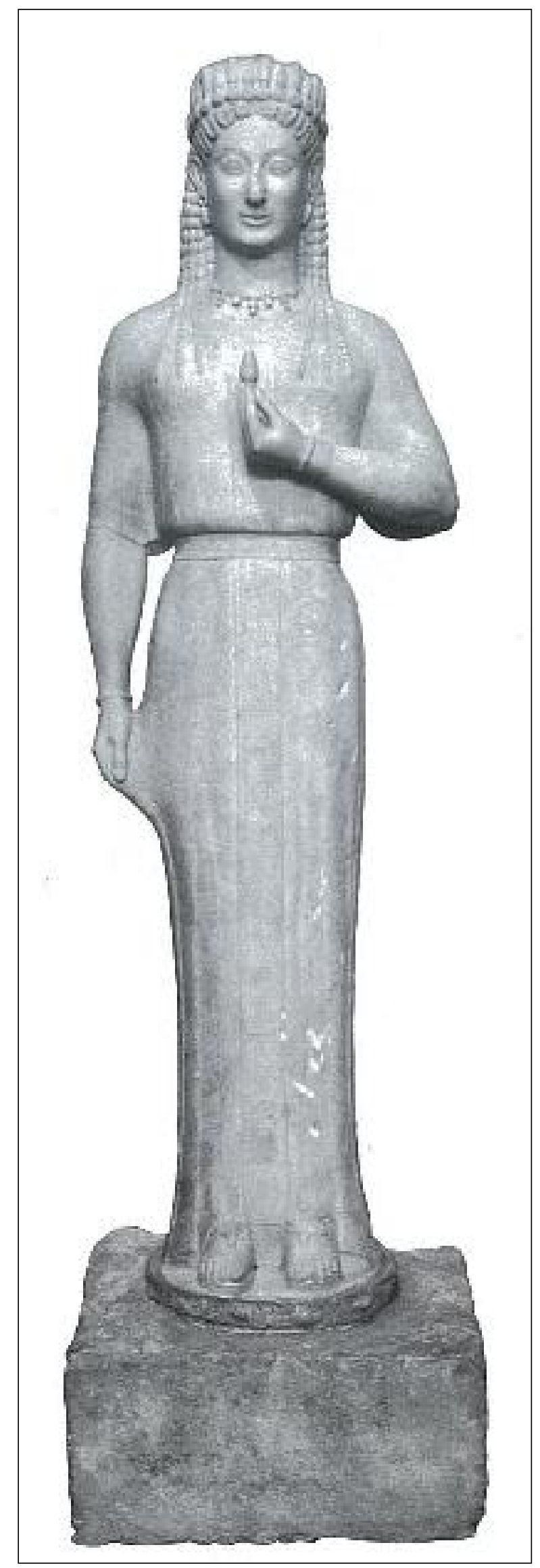

Fig. 9: Attica. Kore of Phrasikleia, by Aristion of Paros. c. 550-540 B.CE. Athens, NM 4889. Hurwit (2007b) Fig. 30. 


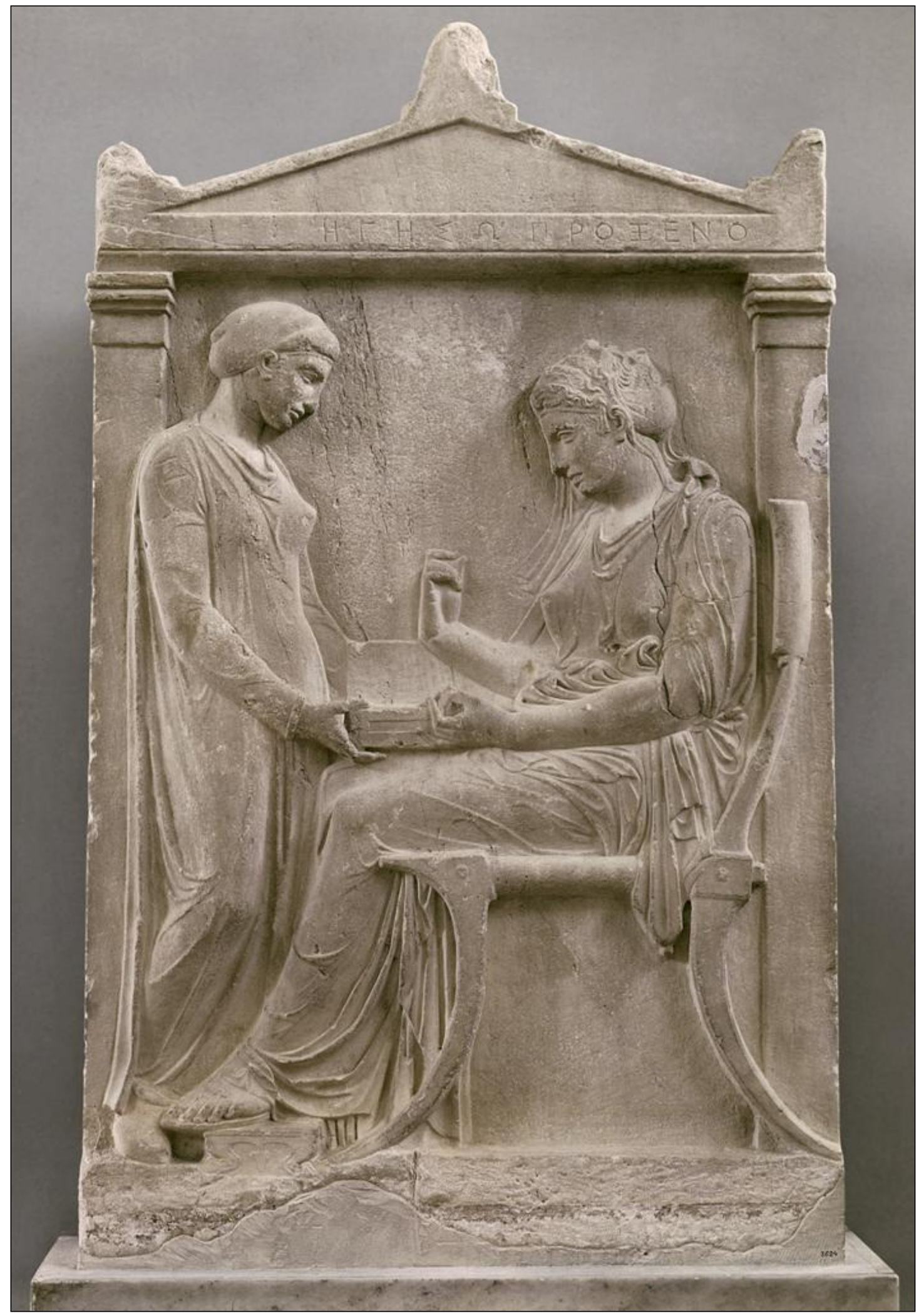

Fig. 10: Kerameikos, Athens. Stele of Hegeso. First quarter of the fourth century B.C.E. Athens, NM 3624. Artstor.org. I.D.: SCALA_ARCHIVES_10310475454 downloaded on 23.08.09. 


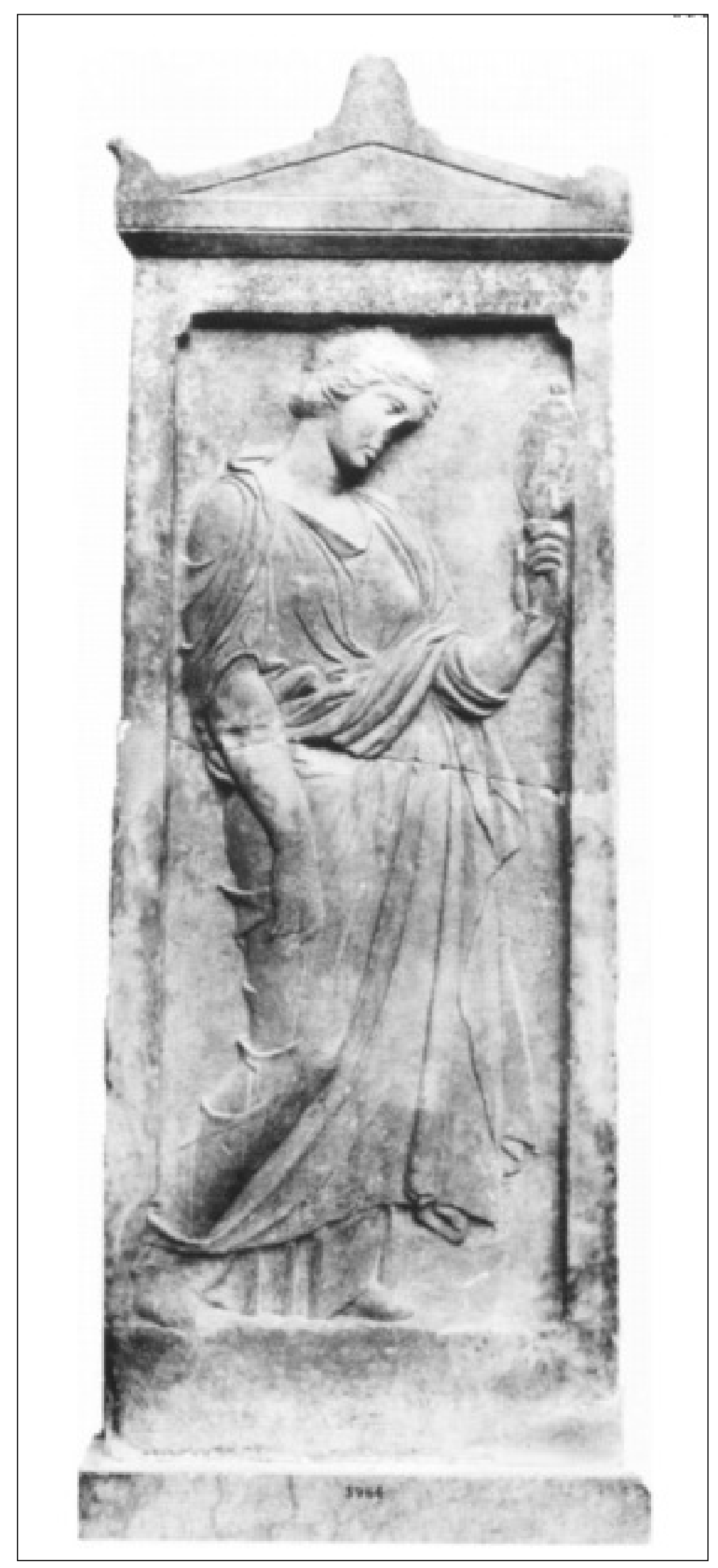

Fig. 11: Stele of Pausimache. First quarter of the fourth century B.C.E. Athens, NM 3964. Leader (1993) Fig. 6. 


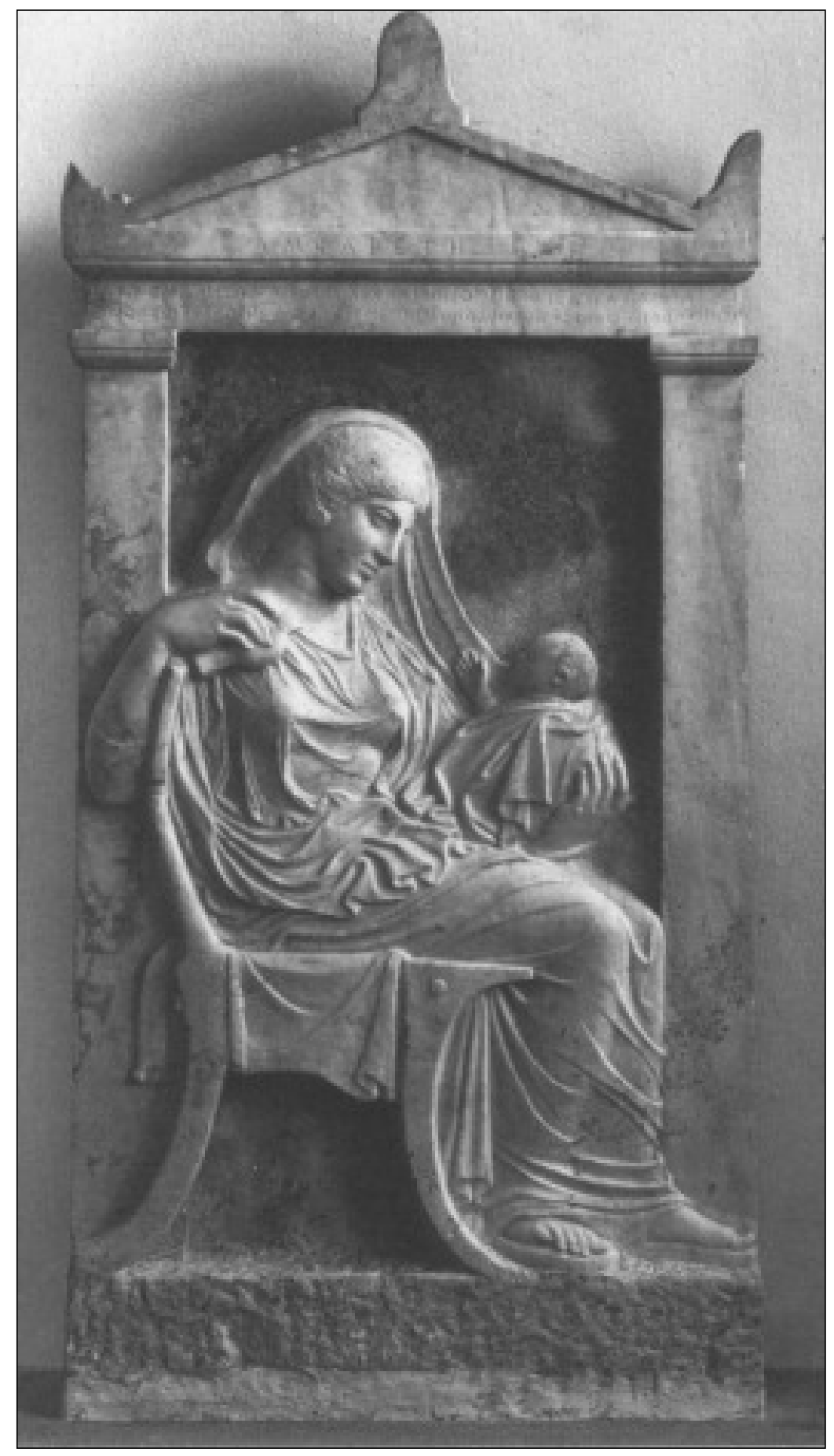

Fig 12: Kerameikos, Athens. Stele of Ampharete. Late fifth century B.C.E. Athens, Kerameikos Mus. P 659,1 221. Sutton (2004) Fig. 17.2. 


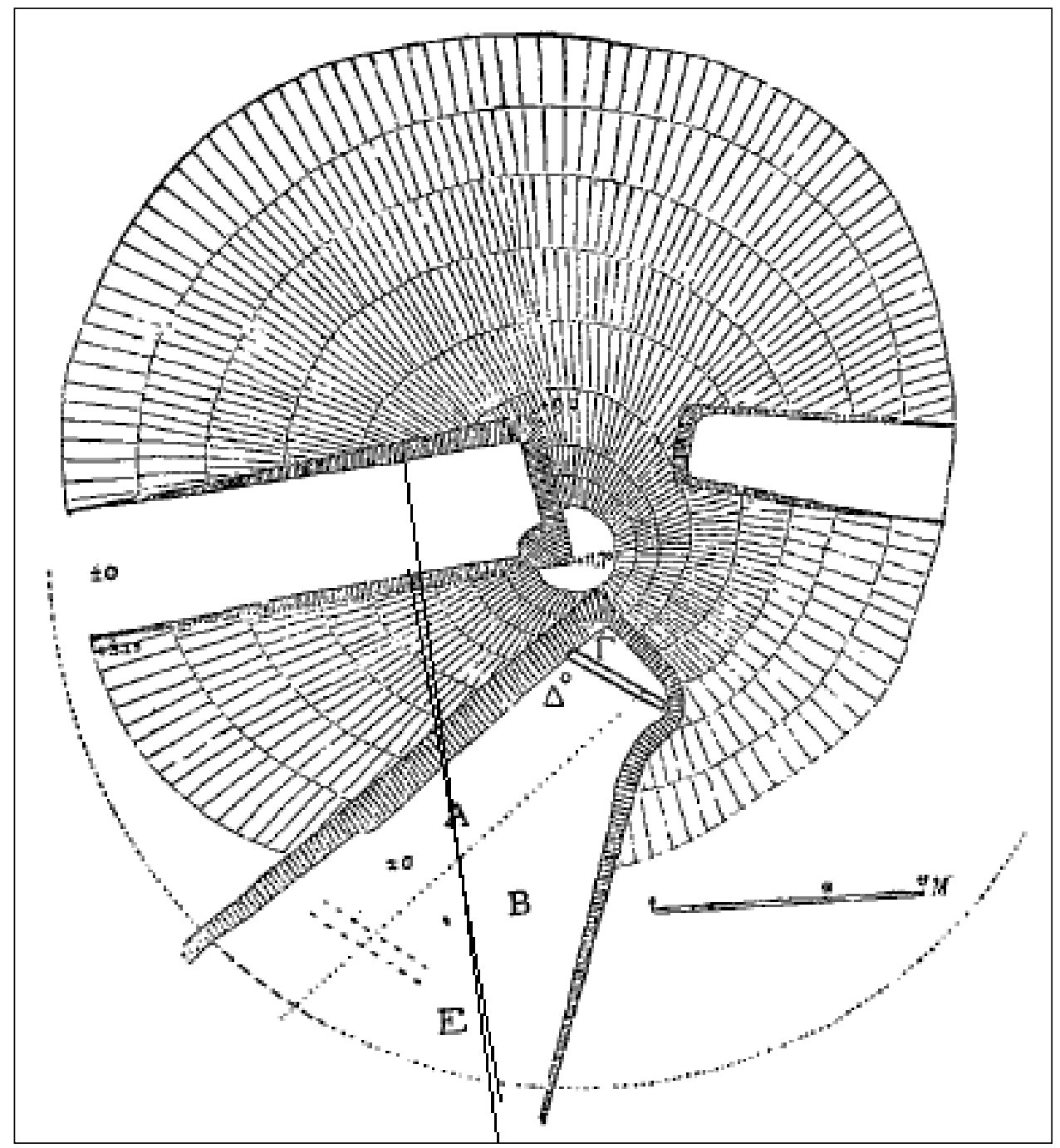

Fig. 13: Plan of the Marathon tumulus. Whitley (2001) 13.20. 


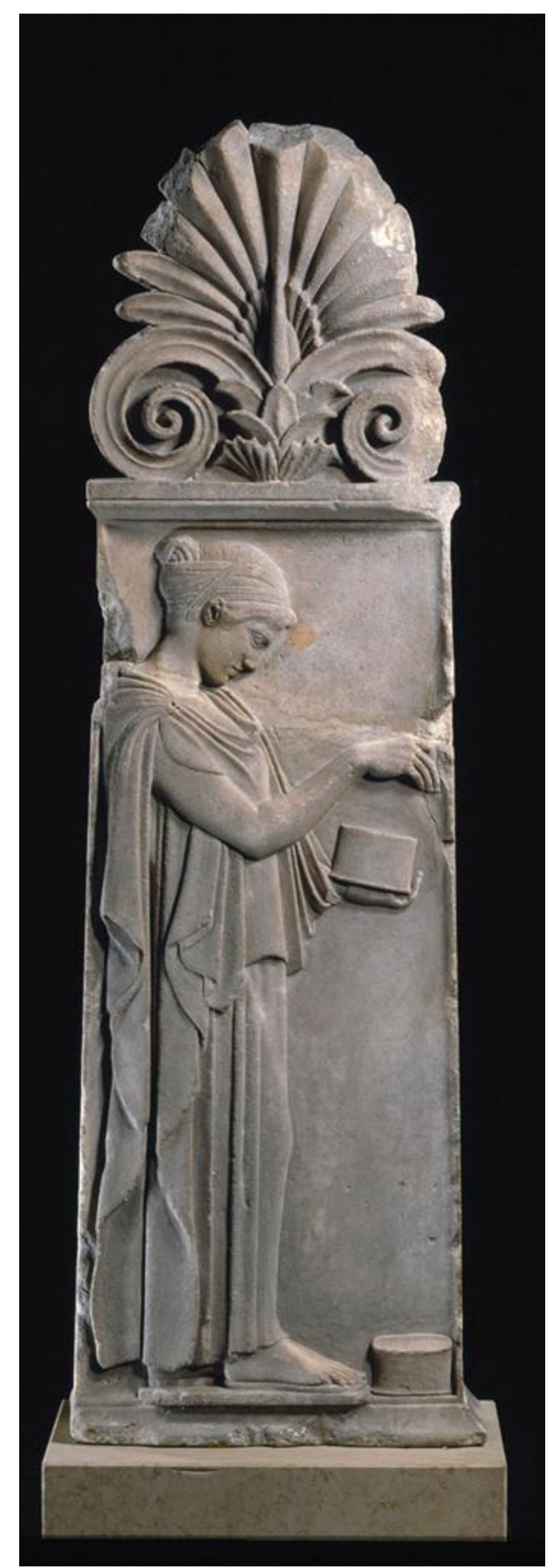

Fig. 14: Paros. 'Stele Giustiniani'. c. 460 B.C.E. Girl with jewellery box (bride of Hades?). Berlin, Antikenslg. Artstor.org I.D. BERLIN_DB_1039764898 downloaded on 21.08.09. 


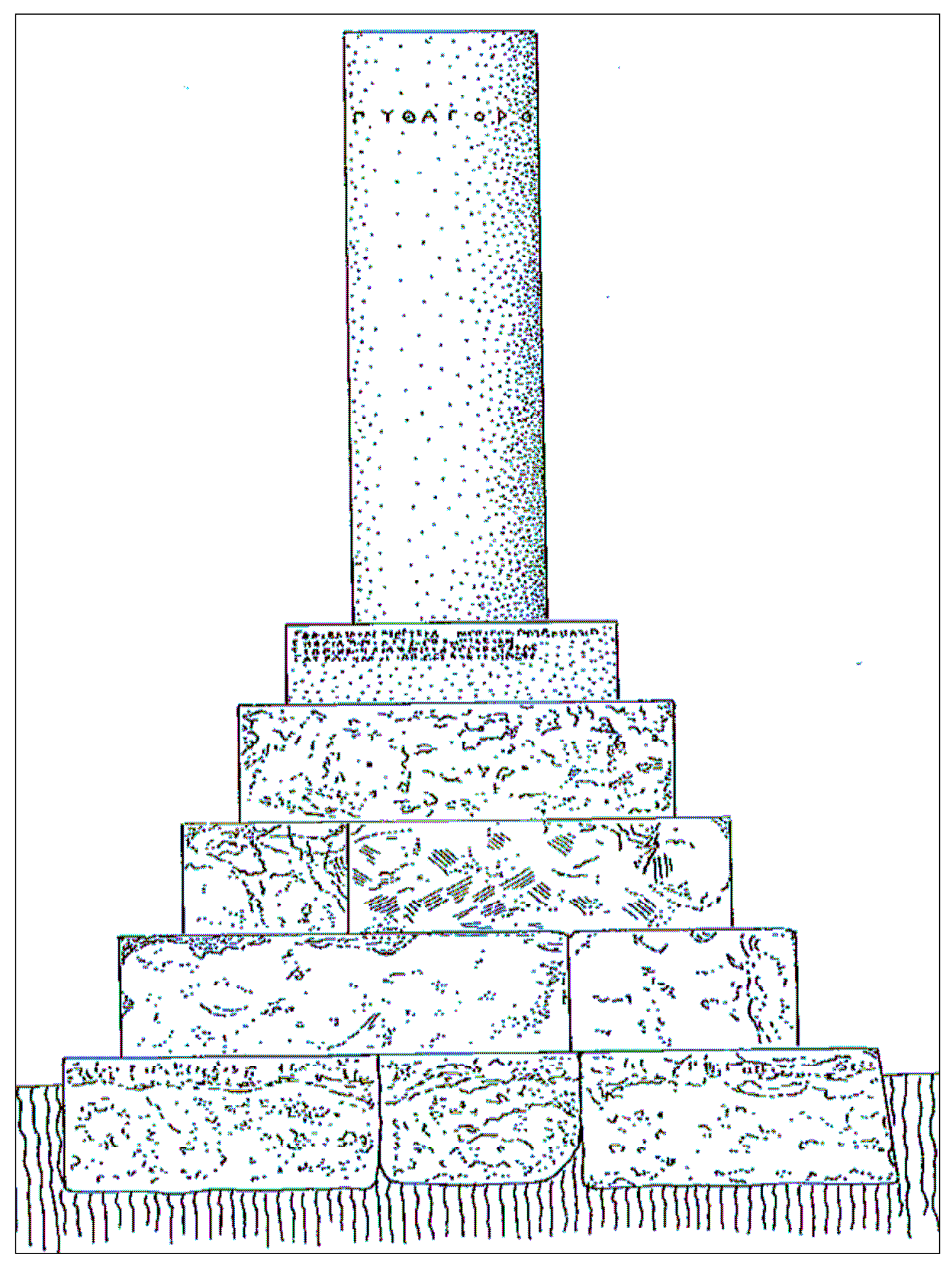

Fig. 15: Drawing of the monument of Pythagoras of Selymbria. Whitley (2001) 367 Fig. 13.21. 


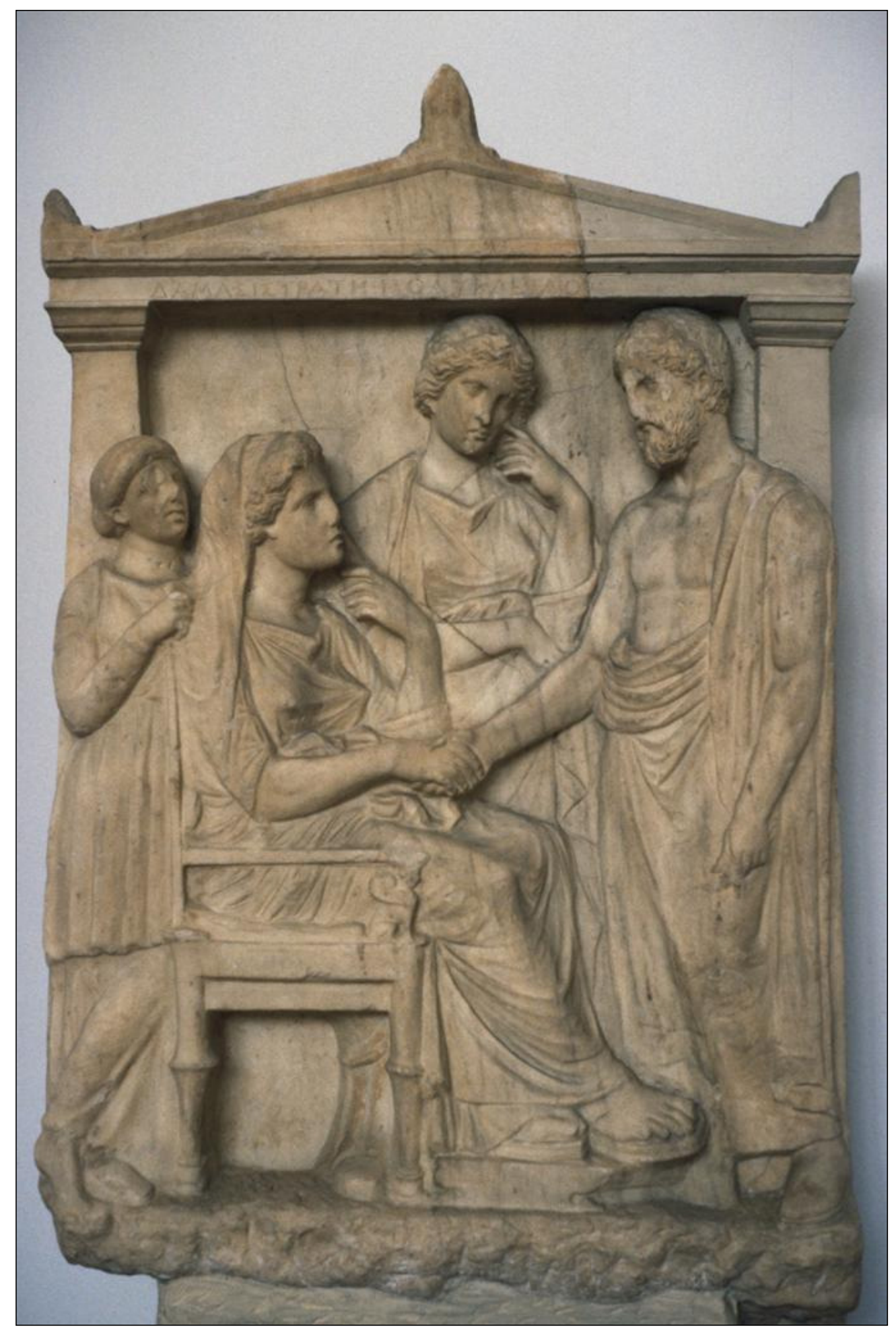

Fig. 16: Grave stele of Damasistrate, showing dexiosis. First half of 4th century B.C.E. NM 743. Artstor.org I.D. AIC_680037 downloaded on 25.08.09. 


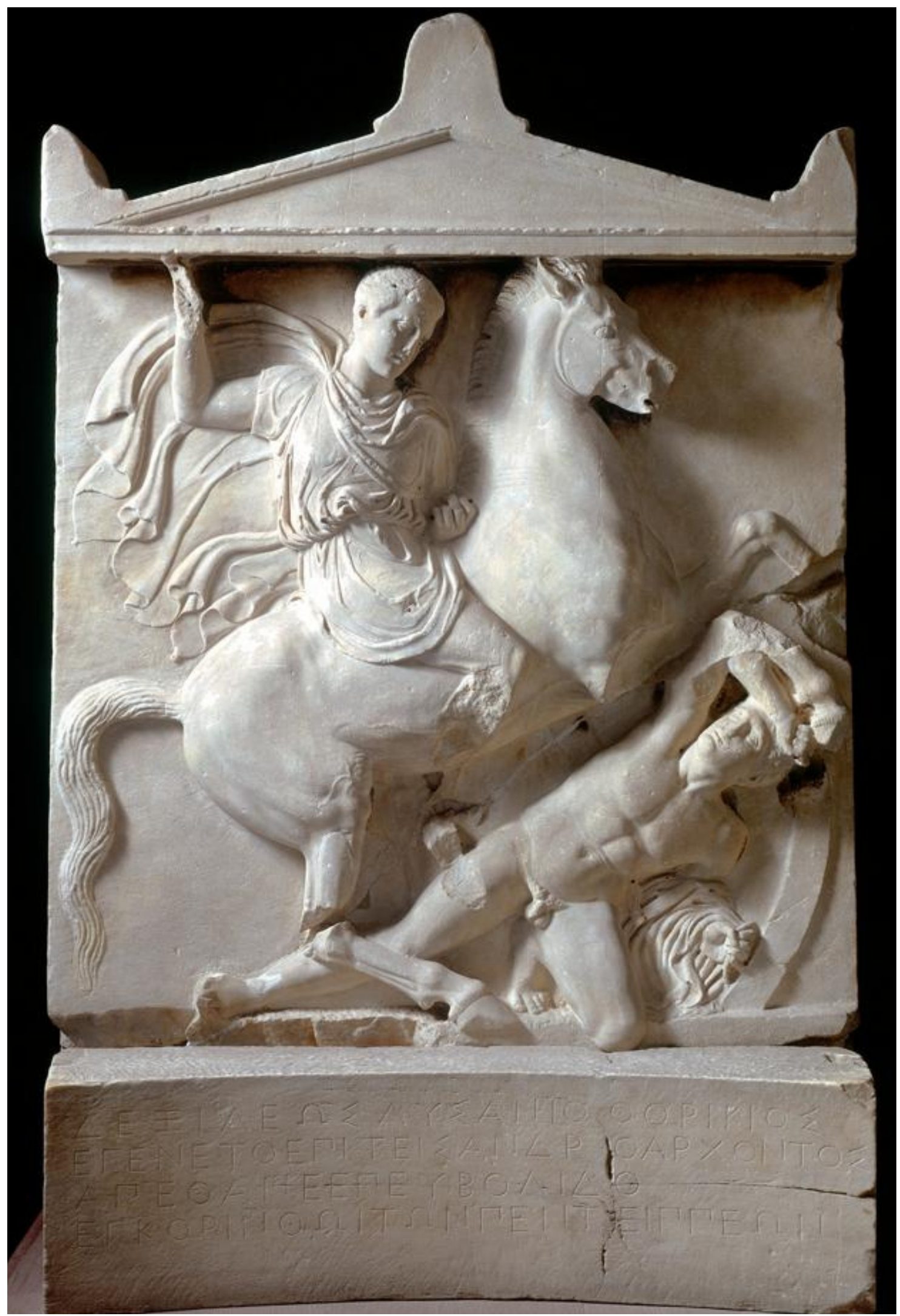

Fig. 17: Athens, Kerameikos. Stele of Dexileos. c. 394-393 B.C.E. Athens, Kerameikos Mus. P.1130. Artstor.org. I.D.: SCALA_ARCHIVES_1039779622 downloaded on 22.08.09. 
